\title{
America's Birth Certificate: The Oldest Globular World Map: c. 1507
}

\author{
Stefaan Missinne PhD \\ Art and Globe Expert, Vienna, Austria \\ Email: missinne@aon.at
}

Received 4 June 2015; accepted 30 June 2015; published 2 July 2015

Copyright (C) 2015 by author and Scientific Research Publishing Inc.

This work is licensed under the Creative Commons Attribution International License (CC BY). http://creativecommons.org/licenses/by/4.0/

(c) (i) Open Access

\section{Abstract}

In 2012, a woodcut print for a c. 11 centimeter globe was discovered in an ancient volume in the University Library in Munich. This pivotal 1 million US\$ globular world map, which only differs marginally from four other extant woodcut copies, attracted worldwide media attention. This discovery ignited the search for the date and the origin of an enigma in the form of an intricate secretive small Renaissance map. The aforementioned had been acquired inserted in a French adapted and unauthorised copy of the Introduction to Cosmography dated 1507 and printed in Lyon. The son of a Dutch American immigrant from Flusching, H. C. Kalbfleisch bought it in Paris in 1881 and brought it to New York. The author offers key evidence that this secretive map is an important misinterpreted and misdated cultural historical prototype which antedates five later woodcut copies: gores in Munich UB, Minnesota-Hauslab, Christie's, SL Munich and Offenburg. He proves that its size and scale are inspired by a calculation of Leonardo da Vinci as described in one of his Codices, and applied on the 1504 Ostrich Egg globe discovered in London 2012. The research methodology used is stemmatics as developed by the German scholar K. Lachmann applied on ancient maps and the evaluation of the scientific aspects and architectural, historical and artistic design. Evidence was offered that the Introduction to Cosmography printed in France in which the engraved map was loosely inserted, together with two additional copper engravings, was printed prior to March 1508. The map research leads to the Benedictine monk and German cartographer, globe constructor and astrologist Donnus Nicolaus Germanus. The latter was the first who constructed a terrestrial and a celestial globe for the library of the Pope Pius IV. The two additional copper engravings lead to the Dutch born medical doctor and astrologer Guillelmus de Wissekerke, supplier of astrological instruments for French kings and the Duke of Milan. The artistic decorator for these copper engravings L. Boulengier was from the city of Albi in France, a possible key stepping-stone to the Papacy in Rome. The cathedral in Albi stood as an architectural symbol against the Cathars. Boulengier drew his inspiration from the Gothic flamboyant style of that world heritage cathedral in his home town Albi. He decorated these engravings on behalf of the powerful and art-loving Florimond de Robertet, Secretary of State for three subsequent French kings including King Francis I, 1515. Robertet was a client of Leonardo da Vinci. A date on two of 
the three artistic prints is a key date for the royalty of France. The French king Louis XII lost the succession of his House Valois-Orléans to the House of Valois-Angoulême after failing to produce a male heir to the throne. The author concludes that the small globular map naming America is America's oldest Birth Certificate. A printed letter-early 1508-by Martin Waldseemüller provides the date. The small map precedes by more than eight years the large woodcut world map discovered in 1903 in Castle Wolfegg (Baden-Württemberg) by the Austrian Jesuit priest Dr. J. Fischer and which was sold to the Library of Congress, in 2001 for US \$10 million. This research is a reappraisal. It is also a rebuttal of a misdirection in the history of science and a misleading error of 133 years ago. It combines medical, geographical, and cultural history of science. It leads the reader through Italian and French Renaissance and concentrates on aspects of architecture, map design, Leonardo da Vinci, French Royalty, and the early discovery of America. It offers a surprising ending leading to the city of New York, named Nouvelle-Angoulême in 1524.

\section{Keywords}

\section{America's Birth Certificate, Cartographic Enigma, Waldseemüller, Leonardo da Vinci, Medical History, New York}

\section{Introduction}

The name of America and its portrayal on cartographic material have been a topic of debate for quite a long time. In this paper, upon presenting the background for this research, a selection of hypotheses and a methodological approach, I examine in great detail the extant globular maps in the form of globe gores and in particular the ones made using the woodcut (in short $\mathrm{W}$ ) technique and a single copper engraving. The latter two are completely different techniques. A topic which has found little attention in the literature namely the watermarks of these globular maps is investigated.

The results of the aforementioned take me to a reappraisal of an inconspicuous print from a small engraved plate. It is a globular map ${ }^{1}$ (in short: this globular map) kept at the New York Public Library. Subsequently I examine the dimensioning of a globe and globular maps in proportion to a diameter of the Earth as calculated by Leonardo da Vinci.

I continue with the aesthetics and the special geographical characteristics of this globular map followed by its provenance. I apply a new approach with a comparative analysis based on the transcription of the Wind Directions on this globular map and some other relevant contemporary cartographic material. This is followed by a brief historical background, the discovery of an architectural detail in a cathedral in France and of a partial watermark on an accompanying engraving.

Then I comment on the artistic and undetected religious aspects of the design of this globular map, part of this enigma. It is followed by strong evidence, based on a defined methodological approach, which leads to this globular map being the birth certificate of America c. 1507.

A remarkable phrase in the Lyon version of the Introduction to Cosmography arouses the interest which is followed by the authorised question if there is any evidence of a contact between the decorator of this globular map and the German cartographer Martin Waldseemüller (c. 1470-1520).

For the interested reader, I present an overview of the arguments which leads to the erroneous attribution and dating of this globular map.

An affiliated copper engraved print titled "Astrolabium Physicum" by Guillaume Gilleszoon de Wissekerke and his endeavours include the print "Motus none Spere" discussed in detail. The reader is guided through a particularly significant section of the history of cartography, the Italian and French Renaissance around the turn of the XVI century, which leads to a surprising ending.

${ }^{1}$ It may be a combined method of Engraving and of Drypoint (puntasecca), as perceived from the visual traces of the hand wiping technique and the directions of the wiping, outside of the borders of the globular map. Even zinc as a basis for the puntasecca, in contrast to copper is possible. An etching press may have been used. The circular ",printing signs” on the corners, which all have a different size, are a remarkable trace that differ from the normal linear impressing due to printing. In a woodcut (relief printing), the wood is cut away. This leaves the areas where there is no more wood white on the paper. 


\section{Background, Methodology, Examination and Comparative Analysis Including Watermarks}

\subsection{Background, Hypothesis and Methodological Approach}

On increasingly regular occasions, the world press reports about the discovery at an auction of a very valuable and early world map. In 1954 the James Ford Bell Library purchased a small early sixteenth century woodcut globular map, intended for a c. $11 \mathrm{~cm}$ diameter globe, for 45.000 US\$, equivalent of roughly 400.000 US\$ (2014 purchasing power).

Thirty seven years later the State Library in Munich paid for another printed version of the same globular woodcut map 2 million Deutsche Mark. Fourteen years later, following a publication of a discovery in a German newspaper, a quasi identical but readily trimmed world globular map was offered for auction at Christies in London and sold for more than 1 million US\$ (www.christies.com/), or c. 20 times the equivalent of a 999.9 fine gold sheet (1 mm thick), to an anonymous buyer.

Only seven years later, in 2012, the University Library in Munich made the pleasant discovery of a very similar printed woodcut globular map. This resulted in worldwide media coverage on its discovery.

In the course of this development of auction sales and revelations, the total but provisional sample of woodcut globular maps increased from 1 to 5 . As it is not unusual for the preparations of auctions, in-house analysts at auction houses base "their analysis" on readily available sources and make use of copy and paste techniques in order to meet auction deadlines.

But on some occasions, authentic research is "combined" and in this case it led to the astonishing result that the so called birth certificates, all bearing the name America, led to the dating in one occasion from 1518 (University Library Munich) and in two occasions from as late as 1527. It was believed all these woodcut maps, all intended for a globe diameter of c. $11 \mathrm{~cm}$, were from the first decennia of the $16^{\text {th }}$ century, when Waldseemüller ${ }^{2}$ printed the "Editio Princeps" of his "Cosmographiae Introductio" i.a. Cosmographic Introduction and of his large world map.

The case that all are intended for a c. 11 centimeter diameter of an unmounted globe may sound irrelevant, but the evidence of the discovery of the Ostrich Egg globe c. 1504 as the cast model for the Lenox globe, preserved at the NYPL, all also having a diameter of c. 11 centimeter enlarged the sample from two to eight. Therefore I test the hypothesis that the aforementioned is not a statistical coincidence.

Elisabeth Harris offered in 1985 (Harris, 1985: pp. 30-53) key evidence with regard to the dating of the large world map by Waldseemüller at the Library of Congress. She used a hyper spectral image of a pastedown to show text from a palm reading manual on the reverse side of the lower right sheet. Thereby she proved that the large world map by Waldseemüller named officially "America's Birth Certificate" at the Library of Congress and purchased in 2002 for US \$10 million, as part of a unique sample of an extraordinary woodcut map codex is a reprint in the form of a printers proof from after 1516 instead of 1507, date of the first edition, of which there is no extant example ${ }^{3}$.

It is now accepted, although rather reluctantly ${ }^{4}$, that the designation of America's Baptismal Document which entails a name but fails the supplementary requirement of a date from the time of the name giving, is no longer valid ${ }^{5}$.

One author who works at the Library of Congress summarizes it this way: "This gives further evidence that the Library of Congress copy of the 1507 map may have been printed at a later date"

The lacking of the name America on the inset of the large Waldseemüller woodcut map is striking and as an-

\footnotetext{
${ }^{2}$ For an excellent work on the nomenclature used by Waldseemüller and Ruysch I refer to Gregory C. McIntosh author of "The Johann Ruysch and Martin Waldseemüller World Maps".

${ }^{3}$ The author does not doubt the historic significance and proof of the so called baptismal passage in volume with the title Cosmographiae Introductio, dated April 1507. The passage with the name of "America" can be compared to a sort of printed, "register of Baptism" (in German "Kirchenmatrikel"), but does not have the form of a loose "certificate". For the discussion on the naming of America I refer to the Essay of Cohen (1988) and his article on "The naming of America: A Fragment we've shored against ourselves".

${ }^{4}$ E. Harris did not make any detailed analysis of the Watermarks of the World Map and the Carta Marina in her excellent study (p. 34). She only refers to Briquet 496 and 497 in Footnote 9. In a more recent LoC paper by H. Hessler, C. Karnes and H. Wanser with the title "Who printed Waldseemüller: Watermark Evidence from the 1507, 1513 and 1516 Maps", from a very small sample of 3 watermarks, after subjection these to mathematical transformation, a statistical conclusion is attempted to prove who the printer „over what was supposedly nearly a decade between there production has led us to speculate, with Harris, on a shorter time range and that the 1507 map in the LoC was printed in the period between 1513-1516" might have been.

${ }^{5}$ See also Hessler (2007), The Naming of America: Martin Waldseemüller's 1507 World Map and the Cosmographiae Introductio.

${ }^{6}$ John W. Hessler and Chet van Duzer, Seeing the world anew. The radical vision of Martin Waldseemüller's 1507 \& 1516 world maps, Library of Congress, p. 46 .
} 
other author recently put it "are critical to designating the document as America' s Birth Certificate" (Seymour, 2007: p. 119).

The same author accepts that "the copy of the 1507 Waldseemüller world map that now resides in the Library of Congress was probably not printed in 1507; rather, it represents a product that was produced some time after 1516" (Seymour, 2007: p. 174)

This is followed by I quote:

"Until another copy of the map is discovered and its date of printing defined, the Waldseemüller map merits its designation as the document that put 'America' on the map and, as such, America's Birth Certificate or Baptismal Document" (Seymour, 2007: p. 175).

Without wanting to complicate this matter, in 1881 the antique book collector from Dutch-American origin Charles H. Kalbfleisch (1839-1891) ${ }^{7}$, son of the pioneer in the US Chemical Industry, mayor of Brooklyn and US Member of Congress Martin Kalbfleisch (1804-1873) (born in Flushing (Vlissingen), Zeeland) purchased an antiquarian lot Nr. $4924^{8}$ from a printed catalogue 9 . It included the description of the Cosmographiae Introductio

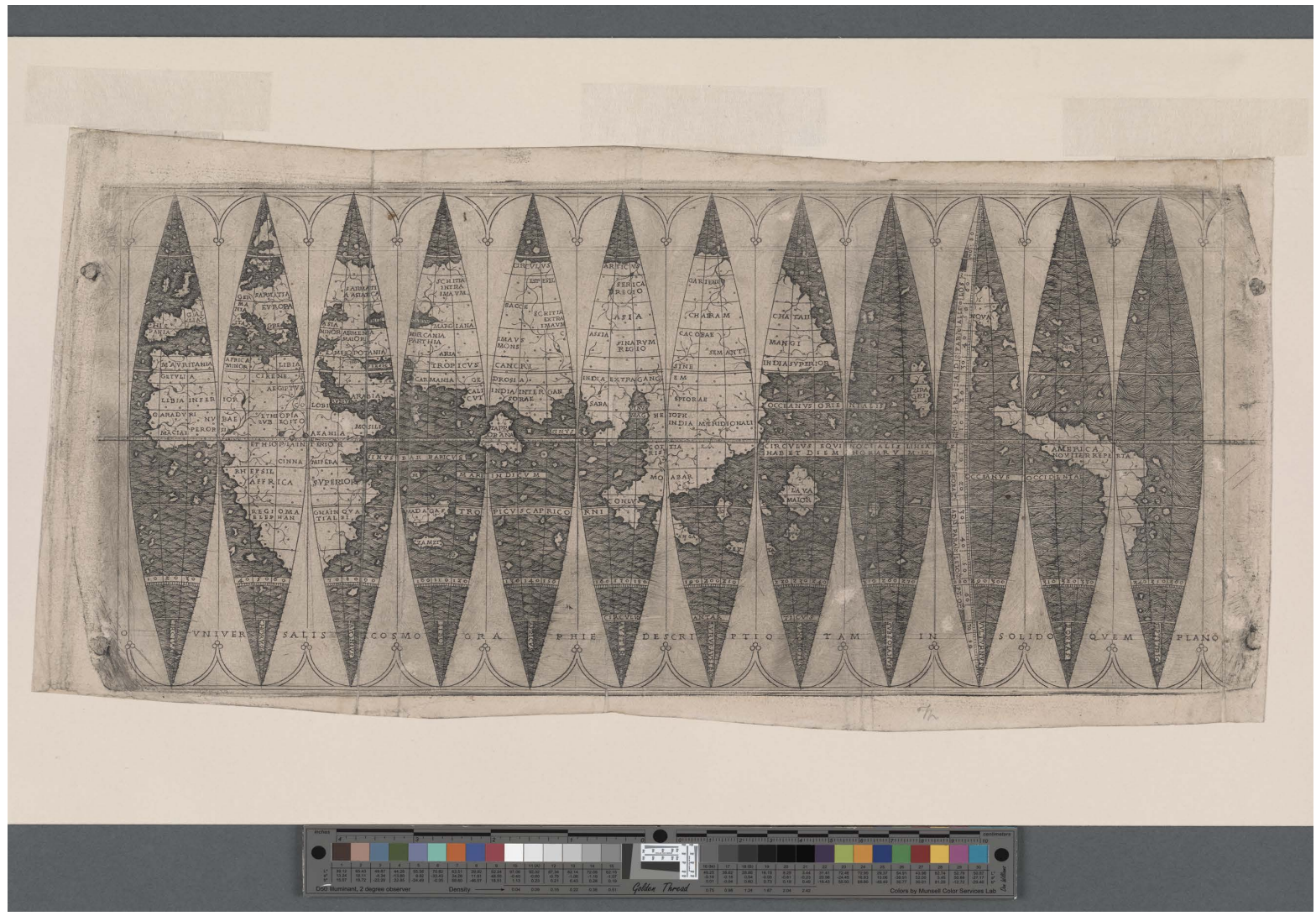

Figure 1. Birth Certificate of America c. 1507.

${ }^{7}$ C. H. Kalbleisch owned a precious library which contained unique examples of early Americana. I refer to Sabin (1885), Dictionary of Books relating to America from its Discovery to its present time, p. 166.

${ }^{8} \mathrm{Nr} .4924$ is listed on p. 612 and 613 of the Antiquarian Catalogue. The French Antiquarian noticed that the name "Jacobo Roberteto" on the second page of the CI of Lyon is scratched "ce nom est grate". I asked the NYPL to controll if this was indeed the case and it was confirmed that the name Robertet had been scratched out twice. I thank Librarian Meridith Mann for her confirmation and picture by mail 6.1.2015. The French Antiquarian also added "(Lugduni, 1514)" to the text of the colophon. The Antiquarian mentions on p. 613 that this map is of French origin and surpassed the oldest map bearing the name America i.e. the codiform double-page woodcut world map by Peter Apian, using Waldseemüller's large world map as a lay out, printed in the Polyistoria of Solinus edited by the Professor of Theology in Vienna, Johannes Camers (Iohannes Cameritus, Italian Minorite born in Camerino 1468-1546). On that map from 1520 America is called "America Provincia". The antiquarian omits any comment to the medical content of the Cosmographiae Introductio printed in Lyon and there is no reference in the catalogue to a reprint of the globular map or the other 2 inserted copper engravings. I thank Samuel Sanchez from the Morres Raphael Cohen Library for his mail dated 23.12.2014. I refer to Vignaud (1912), Americ Vespuce, L'attribution de son nom au nouveaumonde. Extrait du journal de la societé des Américanistes de Paris, p. 295

${ }^{9}$ See G. J. Schwabe, Paris 1880-1882, 11 fascicules reliés en 1 Volume-Editions Originales. 
with a "damnatio memorie" (Censorship) in the form of the scratched out name of Iacobo Robertetum ${ }^{10}$, an unknown globular map (Figure 1 BIRTH CERTIFICATE) and 2 other affiliated copper engravings. It was offered by the Parisian bookseller named H. Tross ${ }^{11}$.

The lot number included a rare volume of the "Cosmographiae Introductio"12 (in short CI) printed in Lyon, France. In this "unauthorised" volume 3 small copper engravings were loosely inserted. Worldwide only one example of these three has survived the ages.

In 1890, the rather "emotional" French researcher L. Gallois presented his PhD thesis in Paris with the title (translated in English): "The German Cartographers from Renaissance"13. In 1898, after its owner, C.M. Kalbfleisch, had passed away, the whole lot passed to the Rare Books Division of the NYPL.

In his doctoral thesis Gallois erroneously dated, without having inspected the single extant original (i.e. blinded research) and therefore exceptional copper engraving ${ }^{14}$ without a name, any kind of honorific dedication on a cartouche or a date. This apparently misled and misdirected much of the later work on early Renaissance globular maps by others since 1890 .

This globular map did not form a part of the print of the CI from Lyon. This new French edition is an adapted volume which cites St. Dié as a source. It is edited by Louis Boulengier. This CI, which has the date of 1507 "Anno post natum Saluatorem sesquimillesimum septimo" but without a specific month, is an adapted Woodcut version of Waldseemüller's second edition April 1507 of the $\mathrm{CI}^{15}$.

The aforementioned does not delete the source of the memorandum St. Dié (Deodati) in the Vosges in the text but logically omits the reference to "Maximiliano Caesari" (Wieser, 1907: pp. 16-17), the Habsburg holy roman emperor Maximilian I (1459-1519), arch enemy of the ruling French King Louis XII amongst others in many territorial disputes and in the Italian wars.

Gallois conjectured and based the date for the loosely inserted and this globular map which he only had known from an auction catalogue from 1881 but never really inspected in concordance with the estimated date of the CI.

So this intricate globular map (Figure 1* America: enlarged globular picture of the American birth certificate (NYPL): @ G. Zotti) with the wording "AMERICA NOVITER REPERTA" which means "recently discovered America" got a date of a publication, c. 1518, attributed to a French Bishop (Ruge, 1892: p. 42). The word "recently" is normally used to indicate that something took place only a very short time ago, and is continuing to happen.

In short, this globular map erroneously got its date when the dedicatee was Bishop of Albi, from 1518. Although this dateless globular map had nothing in common with this Bishop, no one noticed and the erroneous history of cartography got its course.

In order to find out more about the above quoted contradictions, I made a "heuristic" investigation of the extant early Renaissance cartographical material (excluding all globular maps) with particular emphasis on the maps, cartographical reference volumes and globes between 1508 and 1516 which use or omit the word "Amer$i_{c a}{ }^{16}$ (see Table 1(A) and Table 1(B)).

\footnotetext{
${ }^{10}$ According to Dr. Armin Schlechter one has to find the reason for the censorship by scratching out the name, that according to him was contemporary, in the biography of the person whose name was scratched out namely Jacques Robertet. I thank Dr. A. Schlechter for his mail dated 7.1.205. I come back later to this biography.

${ }^{11}$ https://archive.org/stream/bulletinnewyork12librgoog\#page/n26/mode/2up/search/lyons.

${ }^{12}$ The Cosmographiae Introductio was a small book which contained two parts. Part one is an explanatory description of the Universe. It is intended to "educate" and help the reader, and to explain about the large world map which was printed at the same time. The second part is a translation and description of the 4 travels of Amerigo Vespucci. It was the latter part which led to a rapid demand for new editions, particularly as the open and unknown description including such topics as the behaviour of libidinous women (quoted 28 times), naked (quoted 11 times), gold (quoted 8 times), cohabitation, inordinate desires, eating human flesh, the terrestrial paradise, absence of laws, matrimony and commerce, freedom and intimate body parts (pectignone) in the new world. Its imaginative influence had an enormous effect on the demand of the CI and aided to stigmatise the newly discovered part of the world. http://mith.umd.edu/eada/html/display.php?docs=vespucci letters.xml

${ }^{13}$ Gallois (1890), Les Géographes Allemands de la Renaissance. Thése pour le Doctorat. Paris, E. Leroux, 1890, p. 50-52. https://archive.org/stream/lesgographesall00gallgoog\#page/n81/mode/2up

${ }^{14}$ To show the exceptional rarity of this engraving I refer to T. Cambell who lists 1 out of 99 prints. The one which he refers to is a copper engraving but is not a map. It is, a view by the printers Michel Topié and Jacques Heremberck in Le Huen, Lyons France 1488. (Cat nr. 66), T. Campbell, The earliest printed maps 1472-1500, Table 3.

${ }^{15}$ The CI from Lyon has been completely newly typeset for its print by Jean de la Place. Differences include other letters ( $\mathrm{i}$ instead of $\mathrm{j}$ ), other wordings (example: "Rudimenta" is added to the title of the 4 letters of Vespucci), different and more artistic woodcut initials and more important significant differences in the content.

${ }^{16}$ These 2 Tables, based on desk research, exclude the woodcut and copper engraved globular maps. A key finding is that the cartographic material which omit the name "America" are on average 5 times the size of the cartographic material which includes the name "America". In addition a T-Test was made to find correlations but no correlation between the two samples or parts of them could be established. Lastly, the majority of the material using the name America is of German printed origin. The large maps omitting America are principally of Mediterranean origin. I am sure that in the course of history more cartographic material will "surface" to complete this tables.
} 


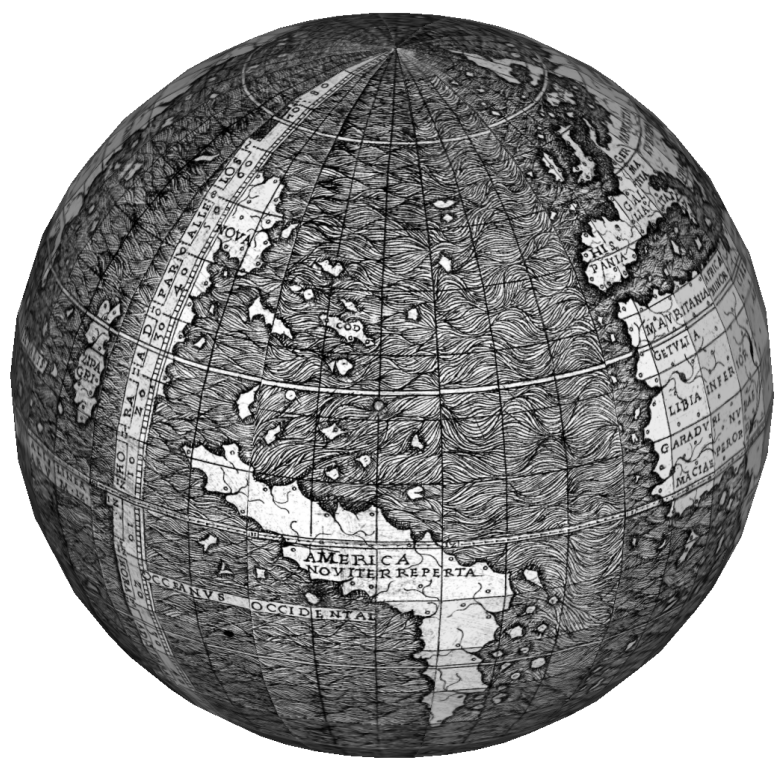

Figure $1 *$. America: enlarged globular picture of the American birth certificate (NYPL): @ G. Zotti.

Table 1(A). Appearance of the word "america" on cartographical material (world maps \& volumes) starting 1508 until 1516 (sample).

\begin{tabular}{|c|c|c|c|c|c|c|c|c|c|}
\hline $\begin{array}{l}\text { IDENFIFICATION } \\
\text {-NAMING }\end{array}$ & SPELLING & c. DATE & $\begin{array}{c}\text { TYPE } \\
/ \text { LANGUAGE }\end{array}$ & TECHNIQUE & AUTHOR & $\begin{array}{l}\text { ORIGIN } \\
\text { /LIB. }\end{array}$ & $\begin{array}{l}\text { WIDT } \\
\text { H } \\
\text { /DIAM }\end{array}$ & $\begin{array}{l}\text { HIG } \\
\text { HT }\end{array}$ & $\begin{array}{l}\text { SURFA } \\
\text { CE }\end{array}$ \\
\hline & & & & & & & $\mathrm{CM}$ & $\mathrm{CM}$ & $\begin{array}{l}\text { Square } \\
\text { CM }\end{array}$ \\
\hline DIE WELT KUGEL & $\begin{array}{l}\text { erfinder Ame } \\
\text { rica heissen }\end{array}$ & 1509 & $\begin{array}{l}\text { VOLUME } \\
\text { /GERMAN }\end{array}$ & WOODCUT & $\begin{array}{l}\text { ADELPHUS } \\
\text { CASTIG. }\end{array}$ & STRASBOURG & 0 & 0 & 0 \\
\hline GLOBUS MUNDI & $\begin{array}{c}\text { america noviter } \\
\text { reperta }\end{array}$ & 1509 & $\begin{array}{l}\text { VOLUME } \\
\text { /LATIN }\end{array}$ & WOODCUT & $\begin{array}{l}\text { ADELPHUS } \\
\text { CASTIG. }\end{array}$ & STRASBOURG & 0 & 0 & 0 \\
\hline $\begin{array}{l}\text { COSMOGR. } \\
\text { INTRODUCTIO } \\
\text { (WSM) }\end{array}$ & $\begin{array}{c}\text { Americi terram } \\
\text { sive Americam } \\
\text { dicendam }\end{array}$ & 1509 & $\begin{array}{l}\text { VOLUME } \\
\text { /GERMAN }\end{array}$ & WOODCUT & $\begin{array}{l}\text { ADELPHUS } \\
\text { CASTIG. }\end{array}$ & STRASBOURG & 0 & 0 & 0 \\
\hline $\begin{array}{l}\text { JAGGELONIAN } \\
\text { GLOBE }\end{array}$ & $\begin{array}{l}\text { AMERICA } \\
\text { NOVITER } \\
\text { REPERTA }\end{array}$ & c. 1510 & $\begin{array}{l}\text { GLOBE } \\
\text { /LATIN }\end{array}$ & BRASS & ANONYMOUS & FRENCH & 7.35 & & 167.71 \\
\hline $\begin{array}{l}\text { PTOLOMY } 1482 \\
\text { ULM Inc } 2 ` 984\end{array}$ & Terra America & 1510 & $\begin{array}{l}\text { MAP COPY } \\
\text { /GERMAN }\end{array}$ & $\begin{array}{l}\text { MS INSERTED } \\
\text { IN VOLUME }\end{array}$ & GLAREAN & $\begin{array}{c}\text { PTO } \\
\text { /BONN VERS }\end{array}$ & 41.5 & 25 & 1037.5 \\
\hline $\begin{array}{l}\text { PTOLOMY } 1482 \\
\text { ULM Inc 2'984 }\end{array}$ & $\begin{array}{l}\text { Terra America } \\
\text { (On the } \\
\text { Southern Half) }\end{array}$ & 1510 & $\begin{array}{l}\text { MAP COPY } \\
\text { /GERMAN }\end{array}$ & $\begin{array}{l}\text { MS INSERTED } \\
\text { IN VOLUME }\end{array}$ & GLAREAN & $\begin{array}{c}\text { PTO } \\
\text { /BONN VERS }\end{array}$ & 41.5 & 26 & 1079 \\
\hline $\begin{array}{l}\text { COSMOGR. } \\
\text { INTROD. } 1507 \\
\text { WSM }\end{array}$ & america & $1510-1513$ & $\begin{array}{l}\text { MAP COPY } \\
\text { /GERMAN }\end{array}$ & $\begin{array}{l}\text { MS GLUED } \\
\text { IN VOLUME }\end{array}$ & GLAREAN & $\begin{array}{l}\text { CI/MUNICH } \\
\text { VERS }\end{array}$ & 41.5 & 25 & 1037.5 \\
\hline $\begin{array}{l}\text { METEROLOGIA } \\
\text { ARIST. J. FABER }\end{array}$ & $\begin{array}{c}\text { Nova Americi } \\
\text { Terra }\end{array}$ & 1512 & $\begin{array}{c}\text { COMMENTARY } \\
\text { /LATIN }\end{array}$ & WOODCUT & COCLAEUS & NUREMBERG & 0 & 0 & 0 \\
\hline $\begin{array}{c}\text { DE GEOMETRIAE } \\
\text { Cod. Lat.1 8959-1 }\end{array}$ & $\begin{array}{l}\text { AMERICA; } \\
\text { A Lucitamis } \\
\text { inventa terra }\end{array}$ & c. 1513 & $\begin{array}{c}\text { MAP COPY } \\
\text { WSM/LATIN }\end{array}$ & $\begin{array}{c}\text { HAND } \\
\text { COL.MANUSC } \\
\text { RIPT }\end{array}$ & GLAREAN & $\begin{array}{l}\text { BASEL } \\
\text { /BROWN }\end{array}$ & 26.6 & 16.7 & 444.22 \\
\hline $\begin{array}{c}\text { DE GEOMETRIAE } \\
\text { Cod. Lat.1 8959-3 }\end{array}$ & $\begin{array}{c}\text { AMERICA; } \\
\text { Terra nova } \\
\text { qua quarta } \\
\text { mundi } p\end{array}$ & c. 1513 & $\begin{array}{l}\text { INSET HEMISP. } \\
\text { MAP WSM }\end{array}$ & $\begin{array}{c}\text { HAND } \\
\text { COL.MANUSC } \\
\text { RIPT }\end{array}$ & GLAREAN & $\begin{array}{l}\text { BASEL } \\
\text { /BROWN }\end{array}$ & 26.6 & 16.7 & 444.22 \\
\hline $\begin{array}{c}\text { DE GEOMETRIAE } \\
\text { Cod. Lat } 18959-5\end{array}$ & America pars & c. 1513 & $\begin{array}{l}\text { NORTH POLE } \\
\text { PROJ./LAT. }\end{array}$ & $\begin{array}{l}\text { HAND COL. } \\
\text { MANUSCRIPT }\end{array}$ & GLAREAN & $\begin{array}{l}\text { BASEL } \\
\text { /BROWN }\end{array}$ & 20.1 & 20.1 & 404.01 \\
\hline $\begin{array}{l}\text { COSMOGRAPHIA } \\
\text { INTRODUCTIO }\end{array}$ & $\begin{array}{l}\text { Americi terram } \\
\text { sive Americam } \\
\text { dicendam }\end{array}$ & 1513 & VOLUME/LATIN & WOODCUT & $\begin{array}{l}\text { WALDSEE } \\
\text { MÜLLER }\end{array}$ & STRASBOURG & 0 & 0 & 0 \\
\hline
\end{tabular}




\begin{tabular}{|c|c|c|c|c|c|c|c|c|c|}
\hline \multicolumn{10}{|l|}{ Continued } \\
\hline $\begin{array}{c}\text { ORBIS } \\
\text { TYPUS-ST } \\
\text {-BROWN A513/1 }\end{array}$ & $A M E R I C A$ & c. 1513 & $\begin{array}{l}\text { MAP (COLOR) } \\
\text { /GERMAN }\end{array}$ & WOODCUT & $\begin{array}{l}\text { ANONYMOUS } \\
\text { (WSM) }\end{array}$ & $\begin{array}{c}\text { GERMAN/BROW } \\
\mathrm{N}\end{array}$ & 57 & 44.5 & 2536.5 \\
\hline $\begin{array}{l}\text { CORNELIUS } \\
\text { AURELIUS }\end{array}$ & $A M E R I C A$ & 1514 & $\begin{array}{l}\text { CHRONYCKEC } \\
\text { /MAP/LATIN }\end{array}$ & WOODCUT & AURELIUS & LEIDEN & 50.5 & 36.5 & 1843.25 \\
\hline PLANIGLOBE & $A M E R I C A$ & c. 1514 & $\begin{array}{l}\text { MAP COPY } \\
\text { /GORE }\end{array}$ & MANUSCR. & $\begin{array}{l}\text { MELZI } \\
\text { (ATTRI) }\end{array}$ & ITALIAN & 12.7 & 12.7 & 126.67 \\
\hline $\begin{array}{l}\text { COSMOGRAPHIA } \\
\text { INTRODUCTIO }\end{array}$ & $\begin{array}{l}\text { Americi terram } \\
\text { sive Americam } \\
\quad \text { dicendam }\end{array}$ & c. 1514 & $\begin{array}{l}\text { VOLUME } \\
\text { /LATIN }\end{array}$ & WOODCUT & BOULENGIER & LYONS & 0 & 0 & 0 \\
\hline SCHÖNER & $\begin{array}{c}\text { AMERI CA, } \\
\text { Terra ultra incognita }\end{array}$ & 1515 & $\begin{array}{l}\text { GLOBE } \\
\text { /GERMAN }\end{array}$ & WOODCUT & $\begin{array}{l}\text { SCHÖNER } \\
\text { (ATTRI) }\end{array}$ & GERMAN & 26.8 & 0 & 2256.41 \\
\hline LUCULENTISSIMA & america & 1515 & $\begin{array}{l}\text { VOLUME } \\
\text { /LATIN }\end{array}$ & WOODCUT & SCHÖNER & GERMAN & 0 & 0 & 0 \\
\hline SCHÖNER & $\begin{array}{l}\text { AMERI CA, Terra } \\
\text { ultra incognita }\end{array}$ & 1515 & $\begin{array}{c}\text { GORE } \\
\text { FRAGMENT } \\
\text { /LATIN }\end{array}$ & WOODCUT & $\begin{array}{l}\text { SCHÖNER } \\
\text { (ATTRI) }\end{array}$ & GERMAN & & 13.4 & 75.39 \\
\hline $\begin{array}{l}\text { QUIRINI/GREEN } \\
\text { GLOBE }\end{array}$ & $\begin{array}{c}\text { america, america } \\
\text { ab inventore } \\
\text { nuncupata }\end{array}$ & c. 1515 & $\begin{array}{l}\text { GLOBE } \\
\text { /LATIN \& } \\
\text { ITALIAN }\end{array}$ & MS PAINTED & ANONYMOUS & ITALIAN & 24 & 0 & 1809.55 \\
\hline & america, america & & & & & & & & \\
\hline $\begin{array}{l}\text { VADIANVS IN } \\
\text { POMPONIUS } \\
\text { MELA }\end{array}$ & $\begin{array}{l}\text { Americam a } \\
\text { Vesputio } \\
\text { repertam }\end{array}$ & c. 1515 & $\begin{array}{l}\text { LETTER/ } \\
\text { VOLUME } \\
\text { E/LATIN }\end{array}$ & WOODCUT & VADIANUS & VIENNA & 0 & 0 & 0 \\
\hline $\begin{array}{c}\text { MS } \\
\text { MAP/KOLLEGIENB } \\
\text { UCH }\end{array}$ & $\begin{array}{l}\text { Terra Incognita } \\
\text { America }\end{array}$ & c. $1515-18$ & $\begin{array}{c}\text { MAP } \\
\text { COPY/GERMAN }\end{array}$ & $\begin{array}{c}\text { MS ON } \\
\text { ADDED } \\
\text { PERGAMENT }\end{array}$ & $\begin{array}{l}\text { S. MÜNSTER } \\
\text { (ATTR) }\end{array}$ & GERMAN/LATIN & 24.3 & 15 & 364.5 \\
\hline \multirow[t]{3}{*}{$\begin{array}{c}\text { Sources: Desk } \\
\text { Research S. Missinne }\end{array}$} & TOTAL SUM: & & & & & & & & $\begin{array}{c}14026.4 \\
3\end{array}$ \\
\hline & $\begin{array}{l}\text { AVERAGE } \\
\text { Square } \\
\text { Centimetre }\end{array}$ & & & & & & & & 935.09 \\
\hline & $\begin{array}{c}\text { Dr. Stefaan } \\
\text { Missinne, } \\
\text { Own Compilation }\end{array}$ & & & & & & & & \\
\hline
\end{tabular}

Table 1(B). Omitting the name "america" on cartographical material (worldmaps, parts and volumes) after 1507 until 1516 (sample).

\begin{tabular}{|c|c|c|c|c|c|c|c|c|c|c|}
\hline NR. & IDENTIFICATION & SPELLING & c. DATE & $\begin{array}{c}\text { TYPE/ } \\
\text { LANGUAGE }\end{array}$ & TECHNIQUE & AUTHOR & ORIGIN & WIDTH & $\begin{array}{l}\mathrm{HIGH} \\
\mathrm{T}\end{array}$ & $\begin{array}{l}\text { SURFA } \\
\text { CE }\end{array}$ \\
\hline \multirow{3}{*}{1} & \multirow{3}{*}{ PTOLOMY } & & \multirow{3}{*}{ c. 1508} & \multirow{3}{*}{$\begin{array}{l}\text { ATLAS MAP/ } \\
\text { LATIN }\end{array}$} & \multirow{3}{*}{ COPPER } & \multirow{3}{*}{$\begin{array}{c}\text { J. } \\
\text { RUYSCH }\end{array}$} & \multirow{3}{*}{ ROME } & $\mathrm{CM}$ & $\mathrm{CM}$ & $\begin{array}{c}\text { Square } \\
\mathrm{CM}\end{array}$ \\
\hline & & $\begin{array}{c}\text { TERRA } \\
\text { SANCTE } \\
\text { CRVCIS }\end{array}$ & & & & & & \multirow[t]{2}{*}{53.5} & \multirow[t]{2}{*}{40.5} & \multirow[t]{2}{*}{2166.75} \\
\hline & & $\begin{array}{c}\text { SIVE } \\
\text { MVNDVS } \\
\text { NOVVS }\end{array}$ & & & & & & & & \\
\hline 2 & ROSSELLI & $\begin{array}{l}\text { TERRA S. } \\
C R V C I S\end{array}$ & c. 1508 & $\begin{array}{l}\text { MAP/ } \\
\text { ITALIAN } \\
\text { COLOR }\end{array}$ & COPPER & $\begin{array}{c}\text { F. } \\
\text { ROSSELLI }\end{array}$ & FLORENCE & 28.5 & 14.5 & 413.25 \\
\hline \multirow[t]{2}{*}{3} & \multirow[t]{2}{*}{ ROSSELLI } & $\begin{array}{c}\text { TERRA S. } \\
\text { CRVCIS } \\
\text { SIVE }\end{array}$ & \multirow[t]{2}{*}{ c. 1508} & $\begin{array}{c}\text { MAP/ } \\
\text { ITALIAN } \\
\text { BLACK \& W }\end{array}$ & \multirow[t]{2}{*}{ COPPER } & \multirow[t]{2}{*}{$\begin{array}{c}\text { F. } \\
\text { ROSSELLI }\end{array}$} & \multirow[t]{2}{*}{$\begin{array}{l}\text { FLORENCE } \\
\text { (BL) }\end{array}$} & \multirow[t]{2}{*}{33.5} & \multirow[t]{2}{*}{18} & \multirow[t]{2}{*}{603} \\
\hline & & $\begin{array}{c}M V N D V S \\
\text { NOVVS }\end{array}$ & & & & & & & & \\
\hline
\end{tabular}




\section{Continued}

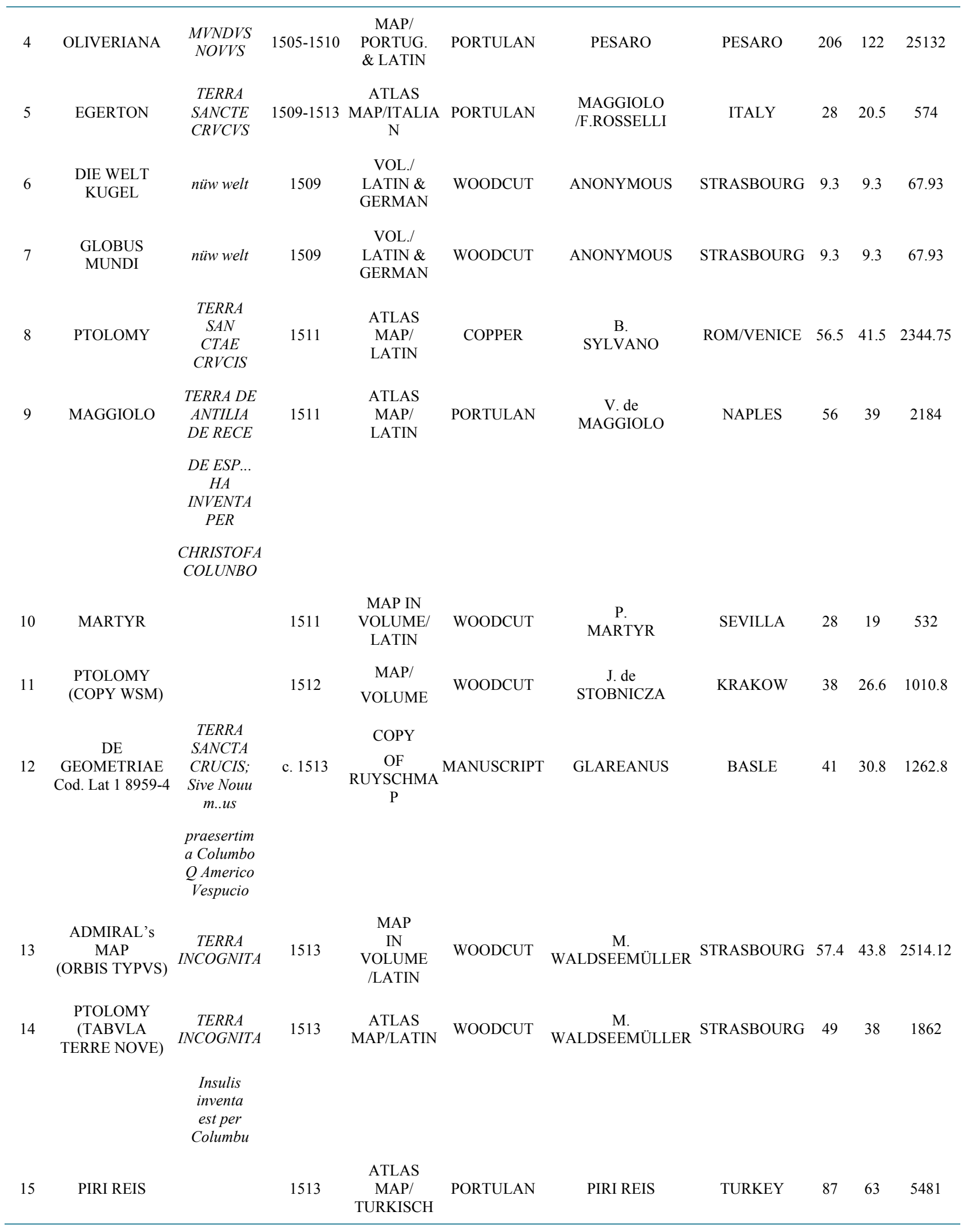




\begin{tabular}{|c|c|c|c|c|c|c|c|c|c|c|}
\hline \multicolumn{11}{|c|}{ Continued } \\
\hline 16 & $\begin{array}{l}\text { MARGARITA } \\
\text { PHILOSOPHICA }\end{array}$ & $\begin{array}{l}\text { Paria sev } \\
\text { pzisilia }\end{array}$ & 1513 & $\begin{array}{c}\text { ATLAS } \\
\text { MAP/LATIN }\end{array}$ & WOODCUT & G. REISCH & STRASBOURG & 28.5 & 13.5 & 384.75 \\
\hline 17 & $\begin{array}{l}\text { MARGARITA } \\
\text { PHILOSOPHICA }\end{array}$ & $\begin{array}{c}\text { ZOANA } \\
\text { MELA/ } \\
\text { PARIA } \\
\text { SEV } \\
\text { PRISILIA }\end{array}$ & 1515 & $\begin{array}{l}\text { ATLAS } \\
\text { MAP/ } \\
\text { LATIN }\end{array}$ & WOODCUT & G. REISCH & STRASBOURG & 44 & 17.5 & 770 \\
\hline \multirow[t]{4}{*}{18} & CARTA MARINA & $\begin{array}{l}\text { TERRA } \\
\text { NOVA }\end{array}$ & 1516 & MAP/LATIN & WOODCUT & $\begin{array}{c}\text { M. } \\
\text { WALDSEEMÜLLER }\end{array}$ & STRASBOURG & 248 & 133.5 & 33108 \\
\hline & \multicolumn{2}{|c|}{$\begin{array}{l}\text { TOTAL SUM OF SQUARE } \\
\text { CENTIMETRES }\end{array}$} & & & & & & & & 80479.08 \\
\hline & \multicolumn{2}{|c|}{$\begin{array}{l}\text { AVERAGE SQUARE } \\
\text { CENTIMETRES }\end{array}$} & & & & & & & & 4471.06 \\
\hline & $\begin{array}{l}\text { Sources: Desk } \\
\text { Research } \\
\text { St.Missinne }\end{array}$ & & & & & & & & & \\
\hline
\end{tabular}

Instead of using a historiographical approach, I use the methodology of comparative analysis of the locational accuracy in maps, the study of size and proportion of the cartographical material, mathematics and text critic, the latter as developed by K. Lachmann.

I present summaries based on authentic research, contacts with world leading experts and offer evidence based on new research.

This article combines the history of the scientific development of globes and technology, including engraving techniques and printing with the practice in the form of medical astrolabe and type of horoscope in the form of a "Motus none Spere".

I test the hypothesis that this globular map is the "Editio princeps" (Laubenbeger, 1959: p. 164) and was copied some ten years later, by woodcutter to construct a small unmounted globe (Figure 1 **: Spacious Woodcut). I test the hypothesis that Waldseemüller did not design any globular maps as part of the so called "media package" of 1507.

This leads to the question: "Where did the engraver of the copper print get his information to depict the Western Hemisphere the way he did?" and "Why do all these examples have a size of ca. 11 centimeters?" and "Is there any proof of a relationship between the large ${ }^{17}$ Waldseemüller map and the globular map?"

The historiographic research took me to Paris, Nancy, St. Dié, Antwerp, Brussels, Gent, Arezzo, Milan, Nurnberg, Bamberg, Rotterdam, Paris, Amsterdam, Bremen, Rome, Kortrijk, Munich, Florence, Vienna, Vinci, Brussels, the Vatican, London, Innsbruck, Ingolstadt, Regensburg and Graz.

I thank the many individuals, academics, librarians, experts and institutions that are listed in the acknowledgements for their support and patience.

\subsection{Examination and Comparative Analysis of the Woodcut and Copper Engraved Globular Maps from the Beginning of the XVIth Century}

Table 2 summarizes in the form of a comparative analysis the "Second Glance" of the extant woodcut globular maps and the copper engraved example (CEGG).

As cited in the introduction, it was the discovery in 2012, of an unknown globular map characterised by crude workmanship detected in the University Library of Munich ${ }^{18}$ bound between two weighty volumes ${ }^{19}$, which

\footnotetext{
${ }^{17}$ Wenn referring to the large Waldseemüller map, I exclusively mean the large map on display at the LoC under the title "America's Birth Certificate" and not the 1516 Carta Marina for which I refer to the excellent article by Van Duzer (2012b) Waldseemüller's World Maps of 1507 and 1516: Sources and Development of his Cartographical Thought", in the Portulan, Journal of the WMS, Issue 85, Winter 2012, pp. 8-20.

${ }^{18}$ Reference is made to the excellent research by Van Duzer (2012a) in his paper "Details, Date, and Significance of the Fifth Set of Waldseemüller's Globe Gores recently discovered in the Munich University Library". 2012, pp. 1-13, Online Version: https://razoncartografica.files.wordpress.com/2012/07/van-duzer-waldseemüller-globe-gores-munich-english.pdf

${ }^{19}$ The volumes are two different versions of Peckham's (1504/1510), Perspectiva Communis published 1504 and 1510.
} 


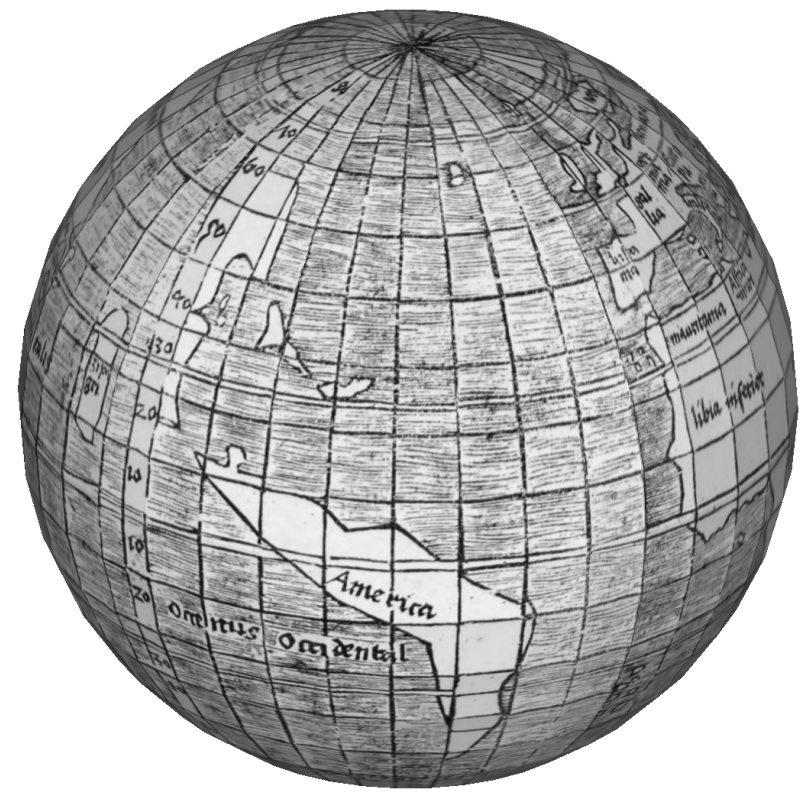

Figure $1 * *$. Spacious woodcut.

Table 2. Examination and comparative analysis of woodcut and copper engraved globe from the beginning of the XVIth century.

\begin{tabular}{|c|c|c|c|c|c|c|}
\hline Globe gores & $\begin{array}{l}\text { Waldseemüller } \\
\text { (attributed) }\end{array}$ & $\begin{array}{l}\text { Waldseemüller } \\
\text { (attrib) }\end{array}$ & $\begin{array}{l}\text { Waldseemüller } \\
\text { (attrib) }\end{array}$ & $\begin{array}{l}\text { Waldseemüller } \\
\text { (attrib) }\end{array}$ & $\begin{array}{l}\text { Waldseemüller } \\
\text { (attrib) }\end{array}$ & “Boulengier” (attributed) \\
\hline & Munich (UB) & $\begin{array}{l}\text { Minnesota } \\
\text { UL/Hauslab }\end{array}$ & $\begin{array}{l}\text { C.Frodsham Ltd. } \\
\text { (Christies) }\end{array}$ & $\begin{array}{c}\text { Kraus } \\
\text { (SL Munich) }\end{array}$ & Offenburg (L) & New York (NYPL) \\
\hline Technique & Woodcut & Woodcut & Woodcut & Woodcut & Woodcut & Copper Engraving \\
\hline Intended diameter & $11.5 \mathrm{~cm}$ & $11 \mathrm{~cm}$ & $10.9 \mathrm{~cm}$ & $11 \mathrm{~cm}$ & $11 \mathrm{~cm}$ & $11.2 \mathrm{~cm}$ \\
\hline Dimension & $35.0 \times 19.0 \mathrm{~cm}$ & $34.5 \times 18 \mathrm{~cm}$ & $34.4 \times 18.0 \mathrm{~cm}$ & $35 \times 18 \mathrm{~cm}$ & $35 \times 18.0 \mathrm{~cm}$ & $36 \times 18 \mathrm{~cm}$ \\
\hline Full Sheet Dimension & $38.0 \times 27.5 \mathrm{~cm}$ & $39 \mathrm{~cm} \times 24 \mathrm{~cm}$ & trimmed gores & $42.3 \times 29.3$ & $38.0 \times 31.5 \mathrm{~cm}$ & $\begin{array}{c}40 \times 20 \mathrm{~cm} \\
(\text { Motus: } 23.4 \times 18 \mathrm{~cm}) \\
\text { Astrolabium: } \\
19.6 \times 20 \mathrm{~cm}\end{array}$ \\
\hline \multirow[t]{2}{*}{ Provenance } & $\begin{array}{l}\text { Old Library } \\
\text { Collection }\end{array}$ & $\begin{array}{c}\text { Vienna } \\
\text { Lib.Liechtenstein }\end{array}$ & $\begin{array}{l}\text { Private Coll. } \\
\text { Germany }\end{array}$ & $\begin{array}{l}\text { Wernigerode } \\
\text { Castle Lib. }\end{array}$ & $\begin{array}{c}\text { Offenburg City } \\
\text { Library }\end{array}$ & $\begin{array}{l}\text { C.H. Kalbfleisch } \\
\text { from Tross in } \\
\text { Paris in } 1882\end{array}$ \\
\hline & $\begin{array}{l}\text { Perspective } \\
\text { Communis } \\
\text { Peckh }\end{array}$ & 1883 & 2005 & $\begin{array}{c}\text { Ptolomy Atlas } \\
1486\end{array}$ & $\begin{array}{l}\text { Edition Aristotle } \\
\text { (1541) }\end{array}$ & $\begin{array}{c}\text { Loose engraving among } \\
3 \text { engravings. } \\
\text { CI. Lyons }\end{array}$ \\
\hline Number of Words & 55 & 55 & 55 & 55 & 55 & 95 or $42 \%$ more \\
\hline Location of the words & $\begin{array}{l}\text { identical with } \\
\text { "Boulengier" }\end{array}$ & $\begin{array}{l}\text { identical with } \\
\text { "Boulengier" }\end{array}$ & $\begin{array}{l}\text { Identical with } \\
\text { "Boulengier" }\end{array}$ & $\begin{array}{l}\text { identical with } \\
\text { "Boulengier" }\end{array}$ & $\begin{array}{l}\text { identical with } \\
\text { "Boulengier" }\end{array}$ & $\begin{array}{l}\text { Identical with } \\
\text { "Walseemüller" } \\
\text { but } 40 \% \text { more }\end{array}$ \\
\hline \multirow[t]{2}{*}{ Identification Watermark } & Picard VII-103 & Picard XVI-371 & Picard XVI-371 & No watermark & No watermark & No watermark \\
\hline & & $\begin{array}{c}\text { Briquet } \\
\text { Nideggan } 1527\end{array}$ & $\begin{array}{c}\text { Briquet } \\
\text { Nideggan } 1527\end{array}$ & & & \\
\hline Date Watermark & Elsass 1518 & Bromberg 1528 & Bromberg 1528 & & & \\
\hline $\begin{array}{l}\text { Chain } \\
\text { Line }\end{array}$ & $2.5-3 \mathrm{~cm}$ & $2.5 \mathrm{~cm}$ & $2.5 \mathrm{~cm}$ & $3 \mathrm{~cm}$ & $2.6 \mathrm{~cm}$ & Linen rag laid paper \\
\hline
\end{tabular}




\section{Continued}

\begin{tabular}{|c|c|c|c|c|c|c|}
\hline & & & & & & $\begin{array}{l}\text { Re Globus Mundi } 1509 . \\
\text { Grüninger }\end{array}$ \\
\hline Location of Caliqut & $\begin{array}{l}\text { West (115th) of } \\
\text { Taprobana }\end{array}$ & $\begin{array}{l}\text { East (145th) of } \\
\text { Taprobana }\end{array}$ & $\begin{array}{l}\text { East (145th) of } \\
\text { Taprobana }\end{array}$ & $\begin{array}{l}\text { East (145th) of } \\
\text { Taprobana }\end{array}$ & $\begin{array}{l}\text { East (145th) of } \\
\text { Taprobana }\end{array}$ & $\begin{array}{l}\text { West (115th) of Taprobana } \\
\text { (see King Hamy Map) }\end{array}$ \\
\hline $\begin{array}{l}\text { Westform of the Island of } \\
\text { Cuba }\end{array}$ & $\begin{array}{c}\text { Bifocal } \\
\text { (grip of a cane) }\end{array}$ & less accentuated & less accentuated & less accentuated & less accentuated & Bifocal (grip of a cane) \\
\hline \multirow[t]{2}{*}{ Size of Madagascar } & $\begin{array}{l}\text { Below } \\
\text { Capricorn. sign } \\
\text { of a }\end{array}$ & Across Capricorn & $\begin{array}{l}\text { Across } \\
\text { Capricorn }\end{array}$ & $\begin{array}{l}\text { Across } \\
\text { Capricorn }\end{array}$ & $\begin{array}{l}\text { Across } \\
\text { Capricorn }\end{array}$ & Below Capricorn \\
\hline & $\begin{array}{l}\text { corrected } \\
\text { woodframe }\end{array}$ & & & & & s. King Hamy Map 1502 \\
\hline Use of "9" for "CVS" & Yes. $6 \mathrm{x}$ & yes. $6 \mathrm{x}$ & yes. $6 \mathrm{x}$ & yes. $6 \mathrm{x}$ & yes $6 x$ & No \\
\hline $\begin{array}{l}\text { Misspelling of LIBIA } \\
\text { INFERIOR \& ZIPAGRI }\end{array}$ & Yes & Yes & Yes & Yes & Yes & $\begin{array}{l}\text { YES LIBIA INFERIOR (after } \\
\text { Ptolomy Bologna 1462/1477 }\end{array}$ \\
\hline Language & Latin & Latin & Latin & Latin & Latin & Latin \\
\hline Cartouche with a dedication & No & No & No & No & No & No \\
\hline NW Continental land ends & Yes & Yes & Yes & Yes & Yes & Yes $<($ after CANTINO 1502) \\
\hline $\begin{array}{c}\text { Number of squares and parts } \\
\text { thereof }\end{array}$ & 666 & 666 & 666 & 666 & 666 & 648 \\
\hline \multirow[t]{2}{*}{ Form of the gores } & $\begin{array}{l}\text { 12th segment } \\
\text { adds } 8 \text { degrees }\end{array}$ & $\begin{array}{l}\text { 12th segment } \\
\text { adds } 8 \text { deg }\end{array}$ & $\begin{array}{l}\text { 12th segment } \\
\text { adds } 8 \text { deg }\end{array}$ & $\begin{array}{l}\text { 12th segment } \\
\text { adds } 8 \text { deg }\end{array}$ & $\begin{array}{l}\text { 12th segment } \\
\text { adds } 8 \text { deg }\end{array}$ & $\begin{array}{l}\text { Length is identical. Width equiva- } \\
\text { lent of } 360 \text { degrees }\end{array}$ \\
\hline & $\begin{array}{l}\text { length differs } \\
\text { (6th is longer) }\end{array}$ & $\begin{array}{l}\text { length differs } \\
\text { (6th is longer) }\end{array}$ & $\begin{array}{l}\text { length differs } \\
\text { (6th is longer) }\end{array}$ & $\begin{array}{l}\text { length differs } \\
\text { (6st is longer) }\end{array}$ & $\begin{array}{l}\text { Length differs } \\
\text { (6th is longer) }\end{array}$ & \\
\hline Gores are numbered & No & No & No & No & No & $\begin{array}{l}\text { YES (upside down). Manual for } \\
\text { construction \& Timeline? }\end{array}$ \\
\hline Number of Figures & 52 & 52 & 52 & 52 & 52 & $\begin{array}{l}80 \text { or } 35 \% \text { more than the wood- } \\
\text { cuts. }\end{array}$ \\
\hline $\begin{array}{l}\text { Text } \\
\text { Below }\end{array}$ & $\begin{array}{c}\text { “Z”“Diameter } \\
\text { Globi” } \\
(11.5 \mathrm{~cm})\end{array}$ & No & No & No & No & $\begin{array}{l}\text { UNIVERSALIS } \\
\text { COSMOGRAPHIE }\end{array}$ \\
\hline \multirow{3}{*}{ Scale duration day/night } & & & & & & $\begin{array}{l}\text { DESCRIPTIO TAM IN SOLIDO } \\
\text { QVEM PLANO }\end{array}$ \\
\hline & 280 degree & 280 degree & 280 degree & 280 degree & 280 degree & 280 degree with hours daylight \\
\hline & & & & & & HABET DIEM HORARVM 12 \\
\hline Intervall of Degrees & $10-360$ & $10-360$ & $10-360$ & $10-360$ & $10-360$ & $10-360$ \\
\hline $\begin{array}{l}\text { Extral } \\
\text { Nomenclatura/ } \\
\text { Decoration }\end{array}$ & None & None & None & None & None & $\begin{array}{c}\text { Wobbly waves } \\
\text { (as Ptolomy Bologna 1462/1477) }\end{array}$ \\
\hline Winds & None & None & None & None & None & YES. 12. \\
\hline \multirow[t]{2}{*}{ Unknown Nomenclatura } & None & None & None & None & None & $\begin{array}{l}\text { COD ("Consecrat. Offert. Dicat"). } \\
\text { GARADVRI. }\end{array}$ \\
\hline & & & & & & $\begin{array}{l}\text { AFFRICA SVPERIOR } \\
\text { (s. Gordianus) }\end{array}$ \\
\hline Extant Number of Samples & 1 & 1 & 1 & 1 & 1 & 1 \\
\hline $\begin{array}{l}\text { Equator drawn } \\
\text { according to } \\
\text { a sea chart }\end{array}$ & $\begin{array}{l}\text { split } 7 \text { th to } 9 \text { th } \\
\text { gore }\end{array}$ & $\begin{array}{l}\text { split } 7 \text { th to } 9 \text { th } \\
\text { gore }\end{array}$ & $\begin{array}{l}\text { split } 7 \text { th to } 9 \text { th } \\
\text { gore }\end{array}$ & $\begin{array}{l}\text { split } 7 \text { th to } 9 \text { th } \\
\text { gore }\end{array}$ & $\begin{array}{l}\text { split } 7 \text { th to } 9 \text { th } \\
\text { gore }\end{array}$ & $\begin{array}{l}\text { Perfect Horizontal } \\
\text { Double engraved Line }\end{array}$ \\
\hline $\begin{array}{l}\text { and not according } \\
\text { to Ptolomy! }\end{array}$ & & & & & & \\
\hline
\end{tabular}




\begin{tabular}{|c|c|c|c|c|c|c|}
\hline \multicolumn{7}{|l|}{ Continued } \\
\hline $\begin{array}{l}\text { Artistic Impression. } \\
\text { workmannship. } \\
\text { inscriptions }\end{array}$ & $\begin{array}{l}\text { clumsy } \\
\text { character }\end{array}$ & crude character & crude character & crude character & crude character & $\begin{array}{l}\text { Excellent workmannship. } \\
\text { artistical. soft ornametal lines }\end{array}$ \\
\hline Hatching & crude & crude & crude & crude & crude & $\begin{array}{c}26 \text { Trifoglio Symb..2 } 2 \times 12 \\
\text { Churchlike Sidechappel Arches. }\end{array}$ \\
\hline Cities. Rivers. coast outlines & $\begin{array}{l}\text { No Jerusalem. } \\
\text { no rivers }\end{array}$ & $\begin{array}{l}\text { No Jerusalem. no } \\
\text { rivers }\end{array}$ & $\begin{array}{l}\text { No Jerusalem. } \\
\text { no rivers }\end{array}$ & $\begin{array}{l}\text { No Jerusalem. } \\
\text { no rivers }\end{array}$ & $\begin{array}{l}\text { No Jerusalem. } \\
\text { no rivers }\end{array}$ & $\begin{array}{l}\text { Jerusalem with Orb \& Cross. } \\
\text { rivers. no mountains }\end{array}$ \\
\hline Mountains & no mountains & no mountains & no mountains & no mountains & no mountains & $\begin{array}{l}\text { Dotts for "cities". Fishlike en- } \\
\text { graving. braided waves }\end{array}$ \\
\hline $\begin{array}{l}\text { AFFRICA. SCHITIA } \\
\text { INTRA IMAUM. ZIPAGRI }\end{array}$ & YES & YES & YES & YES & YES & YES \\
\hline $\begin{array}{l}\text { OCCENUS OCCIDENTAL. } \\
\text { AFFRICA MINOR }\end{array}$ & YES & YES & YES & YES & YES & $\begin{array}{l}\text { NO: OCCEANVS } \\
\text { OCCIDENTAL. AFRICA } \\
\text { MINOR. }\end{array}$ \\
\hline $\begin{array}{l}\text { Congruence of } \\
\text { Continents and }\end{array}$ & $\begin{array}{l}\text { Yes. } 36 \\
\text { islands. }\end{array}$ & Yes & Yes & Yes & Yes & $\begin{array}{l}\text { Yes. but } 238 \text { islands. } \\
\text { (10 times more!) }\end{array}$ \\
\hline \multicolumn{7}{|l|}{$\begin{array}{l}\text { shorelines with } \\
\text { accidental } \\
\text { variation. }\end{array}$} \\
\hline Author & Unknown & Unknown & Unknown & Unknown & Unknown & $\begin{array}{l}\text { A.D. G. (LAYOUT FROM D.N. } \\
\text { GERMANVS) }\end{array}$ \\
\hline $\begin{array}{l}\text { Bibl. } \\
\text { Number }\end{array}$ & Cim. 107\#2 & Bell $1507 \mathrm{mWa}$ & Unknown & $\begin{array}{c}2 \text { Inc.c.a } 1820 \text { a } \\
\quad \# \text { Kt.2 }\end{array}$ & F 327 & $1517+++$ \\
\hline Locations & $\begin{array}{l}\text { UB LMU } \\
\text { München }\end{array}$ & $\begin{array}{l}\text { James Ford Bell } \\
\text { Lib.USA }\end{array}$ & $\begin{array}{l}\text { C. Frodsham } \\
\text { Ltd. London }\end{array}$ & $\begin{array}{l}\text { Munich. BSL } \\
\text { Germany }\end{array}$ & $\begin{array}{l}\text { Offenburg. } \\
\text { Germany }\end{array}$ & New York \\
\hline Purchased & $\begin{array}{l}\text { discovered } \\
2012\end{array}$ & $\begin{array}{l}\text { 45.000 USD in } \\
1954\end{array}$ & $\begin{array}{l}1 \text { Million } \\
\text { US\$ (2005) }\end{array}$ & $\begin{array}{l}\text { 1.5 Million } \\
\text { US\$ (1991) }\end{array}$ & discovered $1993^{b}$ & $\begin{array}{l}\text { bequathed by C.H. Fleischmann in } \\
\qquad 1888\end{array}$ \\
\hline Preliminary Conclusion & $\begin{array}{c}\text { Copy of } \\
\text { copper gores c. } \\
1518\end{array}$ & $\begin{array}{l}\text { Third Variant } \mathrm{c} . \\
1527\end{array}$ & $\begin{array}{c}\text { Third Variant } \mathrm{c} . \\
1527\end{array}$ & $\begin{array}{c}\text { Third Variant } \mathrm{c} . \\
1527\end{array}$ & $\begin{array}{l}\text { Third Variant } \mathrm{c} . \\
1527\end{array}$ & Original c. 1507 \\
\hline $\begin{array}{l}\text { Sources: Individual } \\
\text { Libraries. }\end{array}$ & & & & & & \\
\hline
\end{tabular}

triggered this research.

The following analysis of the extant woodcut globular maps is an imperatively small but not yet completely satisfying step in this research.

The sample of four identical woodcut globular maps that were known until 2012: (Figure 2(A) Woodcut globular Map). Common characteristics are:

- Madagascar is a triangular island across the tropic of Capricorn.

- ZIPAGRI is misspelled. An " $\mathrm{N}$ " is missing 20 .

- Calicut is located on the incorrect side i.e. to the East of TAPROBANA (Sri Lanka) (135th degree).

- "America" is not printed on a horizontal line.

- The latitude notation is in the interval line 280 - 290 degrees East between ZIPAGRI and America.

- The Equatorial double engraved line is split from the $7^{\text {th }}$ to the $9^{\text {th }}$ globe gore.

- The $12^{\text {th }}$ globe gore segment (340 - 360 degrees) ends at 360 degrees.

- All vertical lengths of the woodcut globe segments are equally long.

- At the bottom of the woodcut, there is no specification of a diameter of a round sphere on which the still-to-be-cut-out gores of the globular map are to be glued.

Comparing the above common characteristics mentioned and the woodcut exposed in 2012 in Munich ${ }^{21}$, (Figure 2(B) Globular Map UB Munich) I applied the "spot the difference" technique, which is popular in the cartoon section of weekend editions of many newspapers. This led to the following 5 differences between both

${ }^{20}$ I thank the map expert on Japanese Maps Don Jason Hubbard for his kind explanatory mail from October 28th 2012th. Marco Polo spoke from Chipangu, a word derived from the Chinese Jih-pen-kwe or Kingdom of Japan.

${ }^{21}$ The similarities between the 4 identical and the single extant 2012 version are: ZIPAGRI, America on a horizontal line, identical location of the latitude notation and the same splitting between the $7^{\text {th }}$ and $9^{\text {th }}$ gore. 


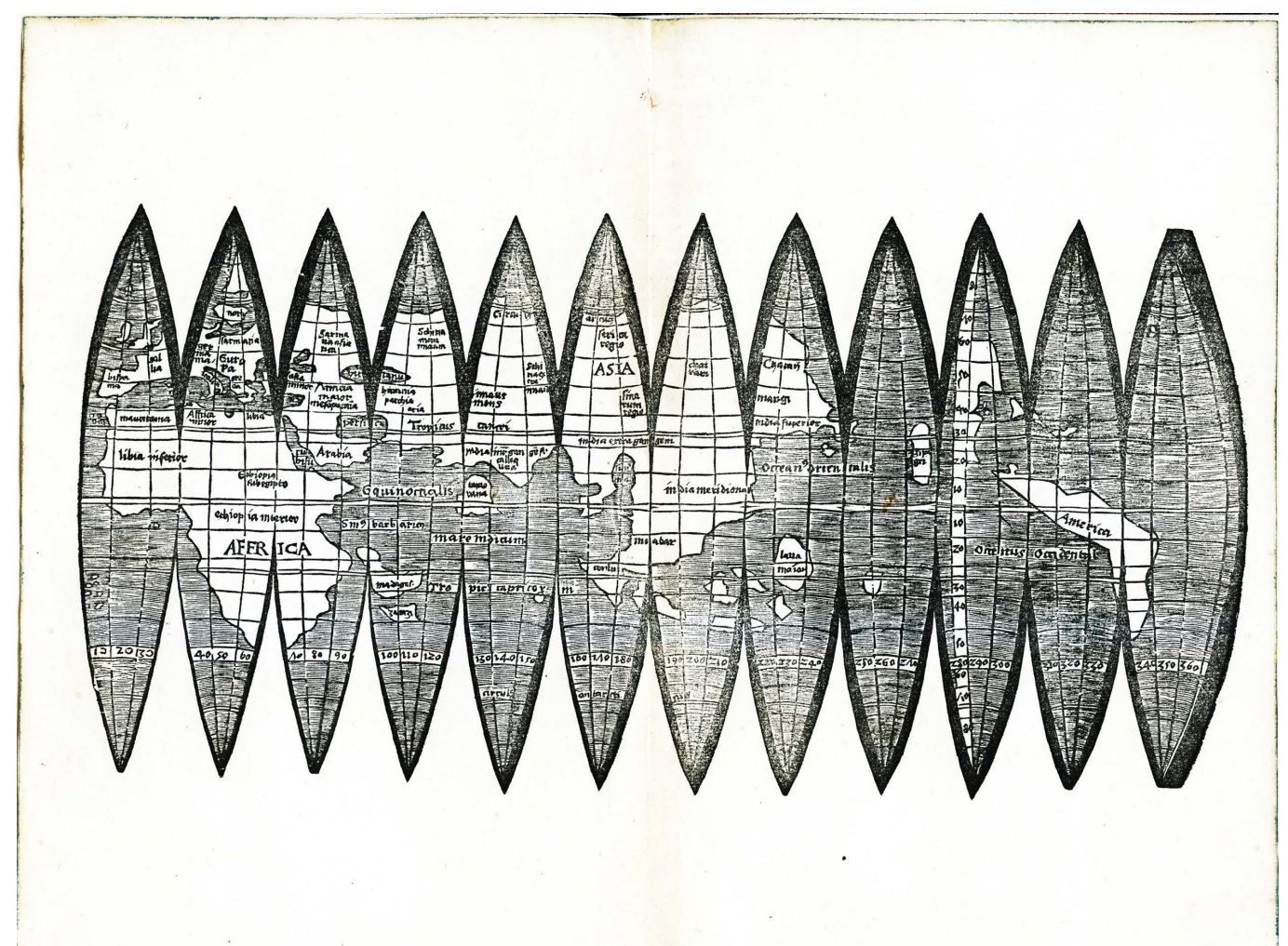

Figure 2A. Globular Woodcut MAP (1 from 4).

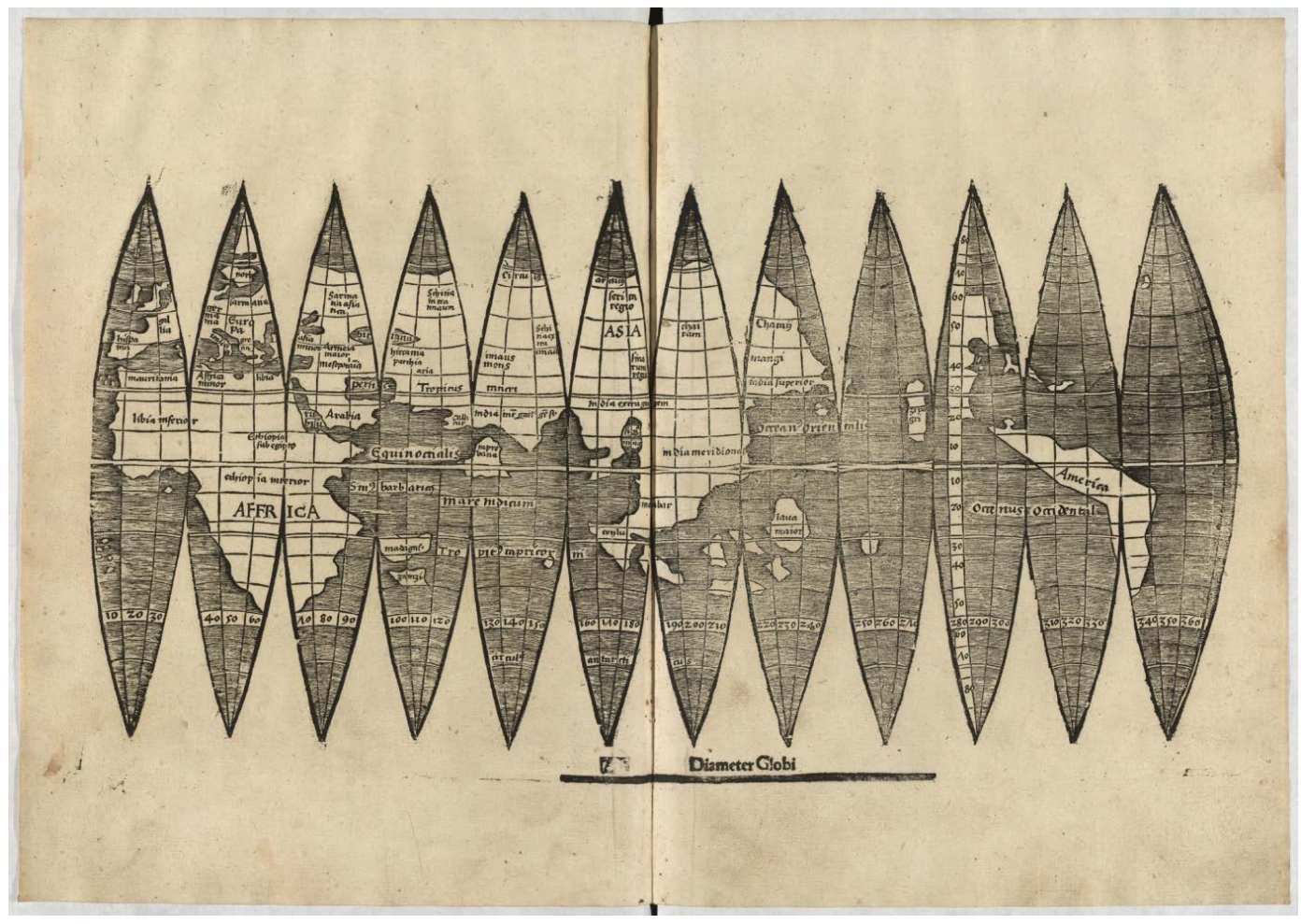

Figure 2B. Globular Woodcut Map UB Munich. 
samples:

- The Island of Madagascar ${ }^{22}$ is smaller and does not cross the tropic of Capricorn ${ }^{23}$.

- Calicut is engraved on the right location which is to the West of TAPROBANA (115 $5^{\text {th }}$ degree), instead of to the East $^{24}$.

- The $12^{\text {th }}$ globe gore segment (340-360 degrees) does not end at 360 degrees, but shows another c. 5 degrees, adding the total of the world circumference to the inaccurate 365 degrees.

- The lengths of the individual globe segments differ from each other. The longest is the $6^{\text {th }}$ from the left. The shortest is the $9^{\text {th }}$ from the left.

- Printed at the bottom, there is a printing aid i.e. a horizontal black line $11.5 \mathrm{~cm}$ long with the words " $\mathrm{Z}$ Diameter Globi" above.

As a picture speaks more than a 1000 words, a summary of the most visible aspects is shown in the Compilation 1 Spacious Copper and 1 Spacious Woodcut.

The woodcut globular map of the UB Munich reflects crude workmanship.

This lesser precision forms an added convincing argument for it being at the beginning of the experimental learning curve of woodcut globular map construction.

In short, I found that there are remarkable differences such as the form and size of Madagascar ${ }^{25}$, the location of the important seaport for spices, "CALICUT", the precision of the gores and the extra printed black line defining the size of the diameter of the ball on which the gores were to be mounted.

Now this research must inevitably lead to the watermarks of the woodcut globular maps.

\subsection{The Presence of Watermarks on Some of the Extant Woodcut Globular Maps}

As these maps are so valuable, no cost was saved by Tom Lamb, then director at Christie's in London to define their provenance prior to auction ${ }^{26}$. The rather technical analysis of the watermarks of the paper and the sheet size is an influential ${ }^{27}$ and objective source for a limitation of their dating and as a source of the paper on which they were printed.

The watermark on the recently identified globular maps at the UB Munich (Cim 107\#2) refers to Piccard Volume 4, 2 p. 190, Div. VII, Nr. 103, 26-27 Elsass and the date: 1518 (!). (http://www.ksbm.oeaw.ac.at/) As stated in a recent paper on the subject "it is possible that the globe gore map was bound together with an Edition of the Volume "Perspective Communiss" published by Peckham in 1510" (Kuttner, 2013: p. 14). So, the binding probably occurred later than 1518.

An expert from the Library of Congress in Washington thinks that the UB Munich globular maps were printed1515/1516, based on the watermark of Cim $107 \# 2^{28}$, in a changed format in Strasbourg using the print setting material from St. Dié (Kuttner, 2013: p. 14).

In addition to the interpretation of this dating to me that does not seem to be a logical statement.

Now I refer to the other single woodcut exemplars kept at/by the ${ }^{29}$

a) University of Minnesota, previously called Hauslab Liechtenstein example (with a watermark ${ }^{30}$ );

\footnotetext{
${ }^{22}$ I agree with Chet Van Duzer that the shape of Madagascar looks different as it does not extend north of the Tropic of Capricorn. In contrast to Chet Van Duzer his arguments op cit. p. 7), this shape of Madagascar was intended and not corrected. It is the initial old shape of Madagascar, prior to its discovery in 1508, as on the Map of King Hamy. (1502-1504). Apparently, for the later versions, plugs were used for emendations and excisions to the woodblocks to give Madagascar its triangular form.

${ }^{23}$ According to Campbell (1978) in "The Romweg-Map as a Physical Object", Imago Mundi, 1978, p. 79, certain rules have to be followed to change woodblock materials.

${ }^{24}$ This change in position is commented on by Chet Van Duzer in his statement that "it is more difficult to know what to make of the change in the position of Calicut alluded to..." Chet Van Duzer, op. cit. p. 7

${ }^{25}$ For the historical and correct depiction of Madagascar thereby crossing the Tropic of Capricorn, based on navigational measurements, I refer to Uhden (1939), The Oldest Portuguese Chart of the Indian Ocean, A.D. 1509, Imago Mundi, Vol.3 (1939), p. 9. This is also the case on the Italian made MS 2803 world map of Egerton. (BL)

${ }^{26}$ Ragnow (2013), The Waldseemüller Globe Gores: Some Challenges and Observations, paper presented for the Philips Society Spring Meeting, Loc, Washington, May $17^{\text {th }} 2013$, p. 5.

${ }^{27}$ On the importance see Footnote 13, p. 13 by Paul Needham in Robin Kinross, A4 and before. In: Towards a long history of paper and their sizes. NIAS, KB Lecture, 11.6.2009

${ }^{28}$ Kuttner (2013), The Worldfocus on Munich, Bibliotheksforum Bayern 07 (2013), p. 14

${ }^{29}$ Le „baptême“ de l'Amérique à Saint-Dié-des-Vosges et le contexte historique et culturel en Lorraine vers 1507, Musée Pierre-Noel, Catalogue d'Exposition, Saint -Dié -des -Vosges, 2007, p. 105

${ }^{30}$ According to Christie's, Sale 7137, Lot 17, June $8^{\text {th }} 2005$ the watermark is defined as: "A bull's head surmounted by cross and entwined serpent with an arrow head tongue". The height of the watermark is $11.5 \mathrm{~cm}$. Horn width is $4 \mathrm{~cm}$. Chain line width is $2.5 \mathrm{~cm}$. Full sheet: 252 $\mathrm{mm} \times 380 \mathrm{~mm}$. http://umedia.lib.umn.edu/node/88357?mode=basic
} 


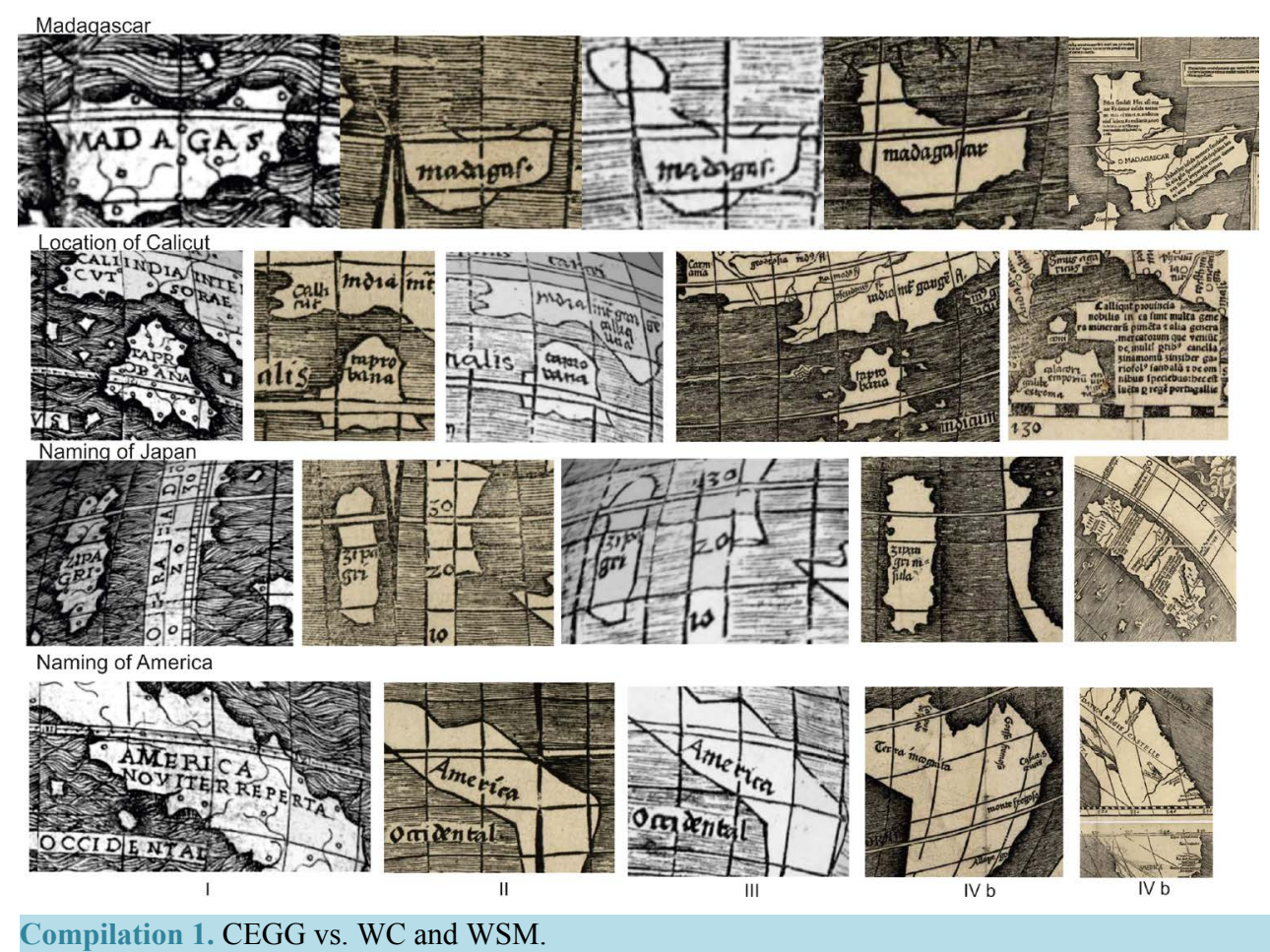

b) Bavarian State Library in Munich, previously called Kraus example (no watermark);

c) Stadtbücherei Offenburg (no watermark);

d) Charles Frodsham and Co Ltd (with a watermark ${ }^{31}$ ) acquired on behalf of an anonymous private collection, which was purchased on June $8^{\text {th }}$ of 2005, Lot 17 , Sale 7137 at Christie's ${ }^{32}$.

Formerly, the map expert H. Harisse thought that the Hauslab Gore map "a" was the oldest, because of the crude workmanship (Harisse, 1892: p. 307) ${ }^{33}$.

The chain line width varies amid these examples between $2.5 \mathrm{~cm}$ and $3 \mathrm{~cm}$. The comparison with the parts of the watermarks of 4 examples of the CI printed in St. Dié led to the conclusion that there is no exact concordance between the paper of the globular maps and the paper used to print the CI, confirming, that there is no evidence that the CI by Waldseemüller had woodcut globular maps attached to them.

For the example d) and although there was no exact concordance with any of the watermarks in Piccard and Bricquet, the detailed analysis by Christie's (http://www.christies.com/lotfinder/) in preparation of the auction led to the dating of Picard XVI-371 (http://www.piccard-online.de/bilder/einleitungen/002.pdf), which is noted as Epstein I. T., Liegnitz, Jagerndorf 1527-30, the 15409 Bricquet mark is Nideggen 1527 and Bromberg 1528.

This means that the four identical woodcut globular maps were printed about 20 years (!) after the printing of the CI in 1507. It confirms my above mentioned hypothesis that the globular map at the UB Munich is indeed the first known state of these woodcuts ${ }^{34}$.

The globular maps attributed to Waldseemüller are no longer valid. Waldseemüller is not the inventor nor the printer of history's mass-produced woodcut miniature globular map. Waldseemüller, known for the incorporating of the latest available cartographical material in his maps, died in 1520.

But if Waldseemüller is not the globular map maker, what was the "inspiration" or prototype for the globular map by the UB Munich?

On the occasion of applying research in preparation for the article on the oldest globe c. 1504 to depict the new world, I came across an inauspicious small sized globular map at the New York Public Library (Figure 1(A)).

\footnotetext{
${ }^{31}$ According to Christie's Sale 7137 , Lot 17 , June $8^{\text {th }} 2005$ the watermark is identical with the example at the University of Minnesota.

${ }^{32}$ I thank CEO Richard Jenning for his personal mail December $3^{\text {rd }} 2014$ who stated that shortly after the purchase a three dimensional globe using a copy of the globular map was constructed with a diameter of $108.33 \mathrm{~mm}$.

${ }^{33} \mathrm{H}$. Harisse, op cit. p. 307. Estreicher refers to the year 1509.

${ }^{34}$ This is supported by Dr. Günther Oestmann in a personal mail dated 15.01.2013. "These recently found woodcut globe gores of Waldseemüller are indeed the earliest until now known globe gores".
} 


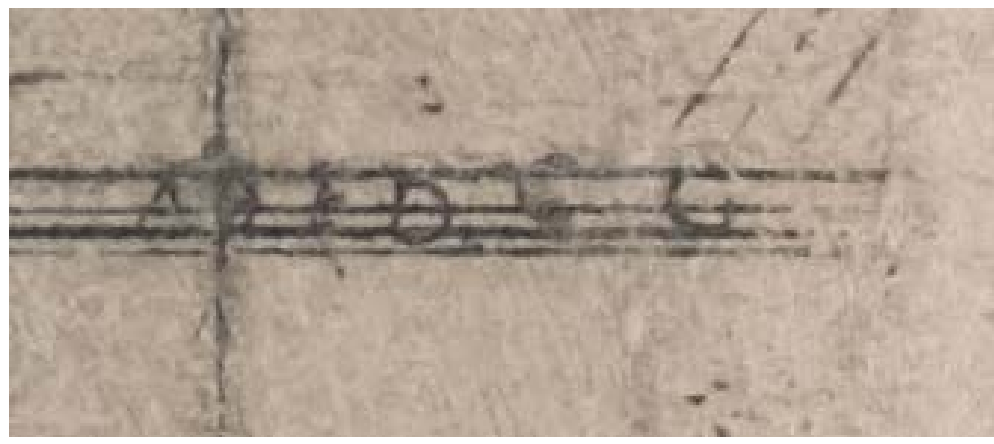

Figure 1A. Detail of A D G.

\section{Reappraisal of the Only Renaissance Copper Engraved Globular Map Bearing the Name America ${ }^{35}$ and Its Attribution}

This globular map is an anonymous, highly artistically decorated map, only known to exist in one single archetype, measuring $18.0 \mathrm{~cm}$ by $36.0 \mathrm{~cm}$, without any date.

The aesthetic character of the globular map using an immaculate technique leads to the assumption that these sections of the globular map were not meant to be cut out, but were made for a didactical, educational purpose.

Unrecognised until now, some hard to decipher letters could be identified on the exterior (on the equator) of the globular map: A B (?) E (?) ${ }^{36}$ D S (?) G (Figure 1(B) Detail of Figure 1(A)). This could be an epigraphic abbreviation $^{37}$.

The first three then could be read as: A (mico) B (benemerenti) fecit ${ }^{38}$.

More likely, the large and clearly distinguishable letters are an abbreviation. The first A for ("ASTROLOGUS"), the middle D for ("DONNUS") and the last for G ("GERMANUS"), which leads to the anonymous map maker and pioneer who as a drawer of the map created the layout for the later engraver. Donnus (=Dominus) Germanus with the full name D. N. Germanus (c. 1420- date of death unknown) was a great cartographer, globe maker and inventor. In 1477 he was in Rome and named himself "DONNUS NICHOLAUS GERMANUS ASTROLOGUS"39.

He was of German ancestry but lived and worked in Italy. Germanus is known for a pair of terrestrial and celestial globes he made in December 1477 for the Franciscan but nepotistic Pope Sixtus IV and his recently opened Library of the Vatican (Babics, 1987: pp. 155-168; http://www.newadvent.org/cathen/11068a.htm).

He is the inventor of the Donis Map Projection, which is exercised in the miniature trapezoidal framework characteristic for this globular map. In this innovative map projection, the parallels of latitude are straight lines equally spaced on the meridians 90 degrees from centre, while the meridians are circular arcs equally spaced along the equator and converge toward the poles. There is symmetry around the central meridian which is straight ${ }^{40}$.

The image of Scandinavia on the globular map is like the piercing across the Arctic Circle, typical for D.N.

\footnotetext{
${ }^{35}$ The literature on the so called Boulengier globe gores includes: Harisse, H., The Discovery of North America, pp. 494-496; Nordenskiöld (1973), Facsimile Atlas, p. 76, Plate XXXVII; Shirley, R.W., The Mapping of the World, Plate 40, Nr. 38, p. 43; Stevenson, E.L., Terrestrial and Celestial Globes, pp. 78-79, Figure 40; Winsor (1884), Narrative and Critical History of America, p. 120.

${ }^{36}$ The E seems to be the mark of a Stone mason. This mark is a signature that pertained to a particular workshop or mason. In Gothic and Renaissance, the stone masons, a fraternal order like the freemasons, were employed by bishops, such as Louis d'Amboise, and kings. They were highly organised and constructed many gothic religious buildings. In the city archives of Albi for the year 1506 the word "Lapicide" or mason was found next to the name of Louis Boulengier. The title used in the archives (4 EDT CC 220, Louis Bolongé) is "maitre" or master. O. Cabayé op cit. p. 32 and personal mail by Dr. O. Cabayédated 1.06.2014.

${ }^{37}$ From an e-mail from Dr. Armin Schlechter, Landesbibibliothekzentrum Speyer dated 26.5.2014, for example „AMICO BENEMERENTI FECIT“. See also George N. Olcottt, Thesaurus Linguae Latinae Epigraphicae. A Dictionary of the Latin inscriptions, 1904, Loescher \& Co, Rome, Vol. I, p. 11

${ }^{38}$ Buck, Klaniczay, \& Németh (1989), Geschichtsbewusstsein und Geschichtsbeschreibung in der Renaissance, Akadémiai Kiadó és Nyomeda Vállalat, Budapest, 1989, p. 81 .

${ }^{39}$ Romuald Bauerreiß OSB, St.-Bonifaz, München, War der Kosmograph Nikolaus de „Donis“ Benediktine? In Studien und Mitteilungen, OSB (1937), Munich, Vol. 55, p. 18

${ }^{40}$ I refer to other early hemispheric maps described by J.P. Snyder and P.M.Voxland. http://www.mapthematics.com/ProjectionsList.php?Projection=203\#Bacon globu larhttp://www.mapthematics.com/ProjectionsList.php?Projection=203\#Bacon globular
} 


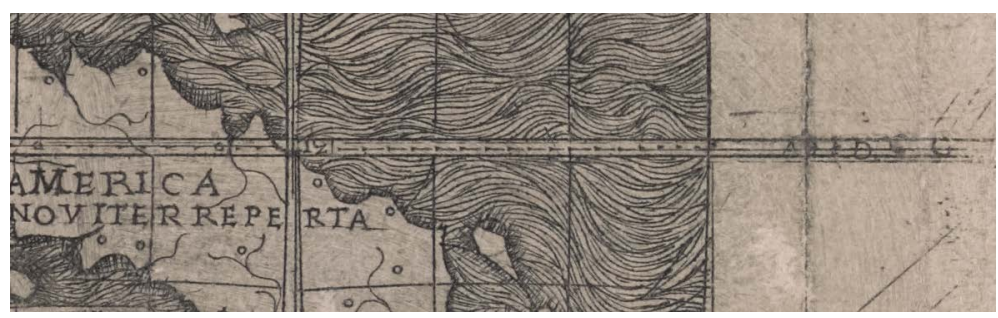

Figure 1B. Detail of the American Birth Certificate.

Germanus and the Ptolemy Map edited in $1482^{41}$. This is in contrast to the later world map of Henricus Martel lus.

As mentioned earlier, it is quite relevant to acknowledge that this globular map is a copper engraving, and not a woodcut. This fact shows a strong Italian influence and likely provenance. It is relevant to remark that this technique was practised predominantly by Dutch and German "expatriates" (Durand, 1952: p. 28) working in Italy such as Konrad Sweynheym and Arnold Pannartz originating from the Rhineland and Henricus Martellus and Johannes Ruysch ${ }^{42}$. The typical German high quality and precision at that time in history surpassed the quality of local Italian engravers.

Prior to 1510, these "Germans" in Italy had more experience in engraving using copper plates, in comparison to their colleagues such as the ones in Strasbourg or Lyon.

The taste for Italian Renaissance Architecture (Martin, 2012: pp. 44-48) was disseminated principally through drawings and engravings in the possession of Italians who settled, some of them in exile due to the Italian wars, in France (Tilly, 1918: p. 384). Another source was German Artists like A. Dürer (1471-1528) who visited Italy.

\section{The Dimensioning of a Globe (Size of the Gores on the Globular Map) in Proportion with the Diameter of the Earth ${ }^{43}$ as Calculated by Leonardo da Vinci}

The copper engraved globular map can be adopted to construct a globe with a diameter of c. $11.5 \mathrm{~cm}$. This is virtually the same dimension as the 5 sets of woodcut globular maps formerly attributed to Waldseemüller, and the same size as the c. 1504 Ostrich Egg globe (Missinne, 2013), the copper cast Lenox Globe, and the woodcut globular map c. 1527 attributed to Peter Apian (1495-1552) (Finsterwalder, 1998: p. 186).

The aforementioned makes an intriguing comment in c. 1521 when he declares that "the world map or geographical map is nothing else than the form or the imitation of a depiction of the world stretched on a surface just as if one would have torn of the membrane or sort of skin of the terrestrial world. In Latin "Membrana de Globo" and can be spread open and pinned on a wall",4 . The Portolan maps, made from goat skin may have served to P. Apian as an example for this pictographic comment.

The attentive reader may have noticed that it may not be coincidental that in a total sample of 8 "globes" (2 globes and 6 printed globular maps) all have relatively the same dimension. In addition all show the circumvention of South America which was discovered by Magellan in 1519 and depict the poles of the earth without land!

To make sure, I applied the $t$ test and used the print dimension (Table 2, Row 3 showing the dimension), plus the data for the Lenox (Diameter: c. 11.2, equivalent of $35.2 \mathrm{~cm} \times 17.8 \mathrm{~cm}$ ) and the Ostrich Egg Globe (Diameter: c. $11 \mathrm{~cm}$, equivalent of $34.6 \mathrm{~cm} \times 17.6 \mathrm{~cm}$ ).

The result of the test: $\mathrm{P}<0.0001$ is considered as extremely statistically significant ${ }^{45}$.

With regard to the circumvention of South America mentioned above, it is my opinion that the latter reflects the abundance of water near the poles of the earth based on Pierre d'Ailly (1351-1420) (McIntosh, 2012: p. 26) his "Ymago Mundi", reflected in Roger Bacon's (1214-c. 1292) "Opus Maius" (Van Duzer, 2002: p. 129) com-

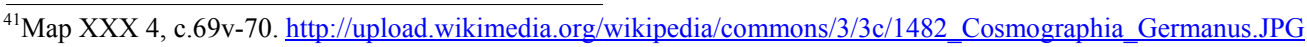

${ }^{42}$ Azzini (2012) “UT VIGINTI SEX TABULAE AENEAE DILIGENTER EXCULPERENTUR”: Domizio Calderini e l'Edizione della Cosmographia Tolemaica (Roma, 1478), Camenae No 10, Février 2012, p. 3. Online on www.paris-sorbonne.fr

${ }^{43}$ I thank Dir. Filippo Camerota, Vice Director from the Museo Gallileo in Florence for his personal mail from the 11.10.2013.

${ }^{44}$ P. Apian, Isagoge, c. 1521, p. 4.

http://dl.ub.uni-freiburg.de/diglit/apian1521/0004/image?sid=91a48a80b8fb925da849a51a2b793565\#current page This very rare pamphlet of which only 3 examples are known was sold for 25.000 USD in NY in 2014. I thank Dr. Biesbrouck for his interpretation mailed on October $2^{\text {nd }} 2014$.

${ }^{45}$ Test applied: December $2^{\text {nd }} 2012$. Group one: Mean $18.1 \mathrm{~cm}$. SD 0.370, SEM 0.131. N 8

Group two: Mean 34.963. SD 0.507. SEM 0.179. N 8. $t=75.9731$. $\mathrm{df}=14$. Standard error of difference: 0.222 Software used:

http://www.graphpad.com/quickcalcs/ttest2/
} 
bined with the estimated size of the world during the Renaissance according to scientists of that time.

The circumference of c. $28.149 \mathrm{~km}$ of the imagined size of the Renaissance world, with a calculated diameter of 7.000 miles $^{46}$, using $1.280 \mathrm{~m} /$ nautical mile, leads to a c. $11.2 \mathrm{~cm}$ diameter of a globe and a scale of 1:80,000,000. This was tested empirically on the Lenox globe at the NYPL, to which I proceed later.

The diameter of the smaller world during Renaissance ${ }^{47}$ was calculated by someone who lived during this Renaissance in Tuscany and who wrote this down. The person I refer to is Leonardo da Vinci. The diameter of the Renaissance world as reported by Leonardo measured 7.000 miles $^{48}$.

This is inscribed by Leonardo in his Codice Atlanticus $311 \mathrm{r}$ and Codice Leicester $35 \mathrm{v}$. He does not refer to a land mile as each city had its own land mile but he refers to nautical miles as proven from his Manuscript MS F 68v (Cantile, 2003: pp. 303-310).

In order to define the above mentioned scale, the empirical test was performed by the librarian Kyle R. Triplett from the Rare Books Division, of the NYPL. He was asked to measure, using a straight line, distances on the Lenox, and to document this.

(Figure 3(A) and Figure 3(B): Scale of the Lenox Globe Measuring. Courtesy of the NYPL Rare Book Division)

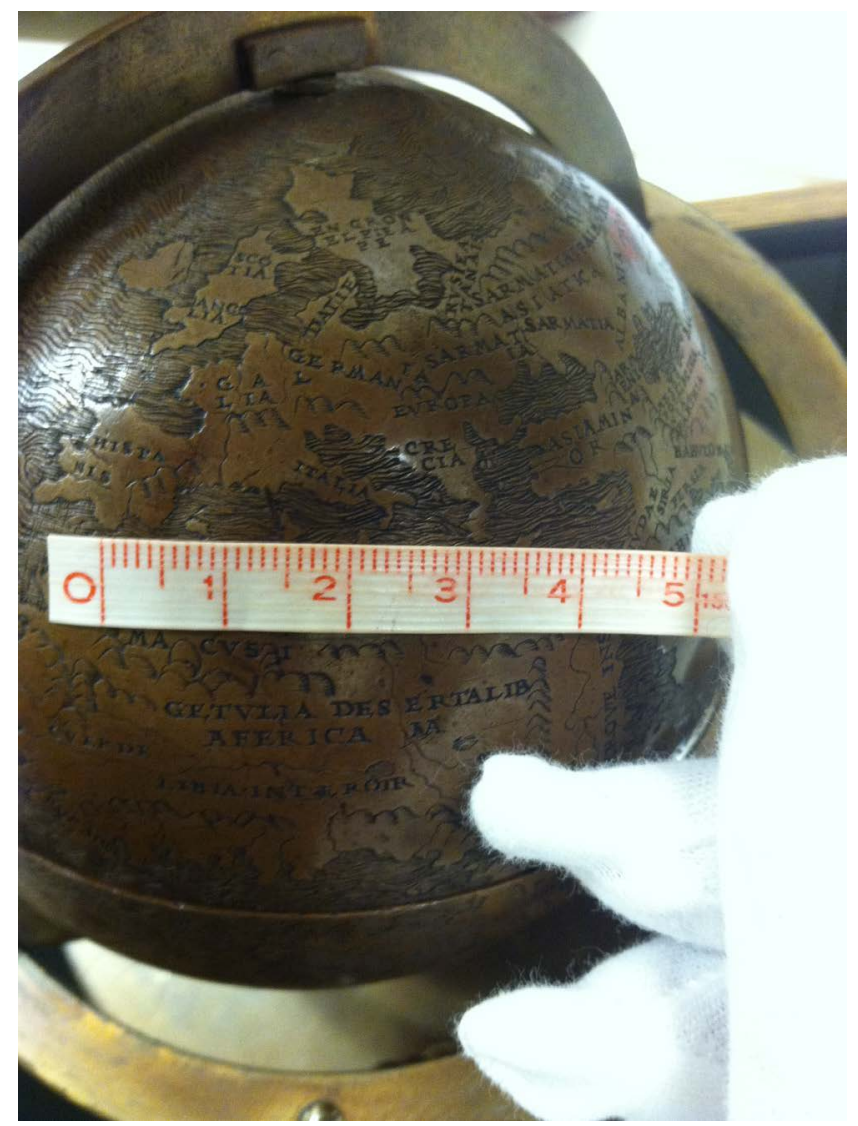

Figure 3A. Lenox globe scale measuring 001.

\footnotetext{
${ }^{46}$ In a personal email from Dott. Filippo Camerota from the Museo Galileo in Florence dated October $10^{\text {th }} 2013$, Camerota comes to a world diameter of 6.912 miles or 1, 26\% less than the 7000 miles as defined by Leonardo.

${ }^{47}$ Claudia Borgioli and Leonardo Rombai (2013), Amerigo Vespucci i.e. Mercanti Viaggiatori Fiorentini del Cinquecento a cura di Margherita Azzari e Leonardo Rombai, Firenze University Press, 2013, p. 182.

${ }^{48}$ Leonardo did not use land miles for the measuring of the sea. Each city had its own mile. He applied nautical miles instead as written down in the Manuscript F nr. $68 \mathrm{v}$ where he quotes "carta da navicare" or map to navigate, when making references to nautical miles in the Mediterranean. http://www.leonardodigitale.com/ The nautical mile in the Mediterranean was c. $1.280 \mathrm{~m}$. See Annex F of the PhD. Thesis by Dr. Joaquim Caspar, From the Portulan Chart of the Mediterranean to the Latitude Chart of the Atlantic. Cartometric analysis and modelling. University of Lisbon, 201. He refers to Italian miles with an average of $1.248 \mathrm{~m} /$ nautical mile and the Majorcan with $1.283 \mathrm{~m} / \mathrm{nautical}$ mile. http://www.ciuhct.com/online/docs/thesis_joaquim_gaspar_2010-v2.pdf
} 


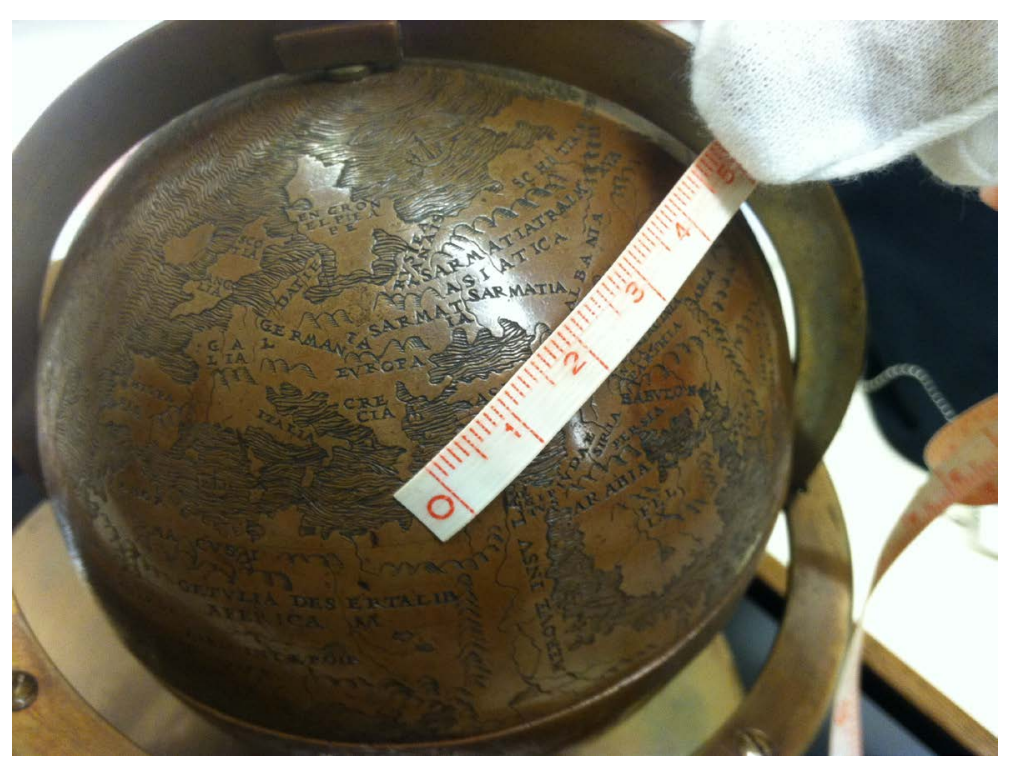

Figure 3B. Lenox globe scale measuring 002.

The first distance (A) was from the Strait of Gibraltar to the South-Eastern part of Greece (Cape Malea). The result for $\mathrm{A}$ is $3.42 \mathrm{~cm}^{49}$. The second distance $(\mathrm{B})$ measured was from the South-Eastern part of Greece to the North-Western part of the Sea of Azov (now Rostov on Don): The result for B is $2.2 \mathrm{~cm}$.

These distances today are A: c. $2.730 \mathrm{~km}$; B: c. $1.750 \mathrm{~km}$. Added up A + B = 5.62 cm on the Lenox or today's equivalent (using a straight line) of $4.480 \mathrm{~km}$. The scale of the Lenox therefore is: 79.715 .302 or the result of 4.480 .000 meters $0.0562 \mathrm{~cm}$.

Effortlessly inferred:

One centimeter of distance on the Lenox equals a distance of $800 \mathrm{~km}$. A few critics may, of course, ask about the curvature of the earth, the application of spherical trigonometry and issues pertaining to the temperature of the copper ${ }^{50}$ at the time of the measurements etc... Fact is that the c. $11.2 \mathrm{~cm}$ reflects the 7000 mile as defined by Leonardo da Vinci as $1 \mathrm{~cm}$ on the Lenox Globe equals c. $800 \mathrm{~km}$..

Another meaningful preliminary conclusion, based on the evidence that the Lenox is a cast from the Ostrich Egg globe, is that, one cannot change the size of an Ostrich Egg without breaking it. Only one globe (with this particular diameter) can be constructed with this scale reflecting the 7000 nautical renaissance mile calculation of the world as measured and composed by Leonardo da Vinci.

The $11.2 \mathrm{~cm}$ differs only $3.4 \%$ from 4 soldi or $11.6 \mathrm{~cm}$. More notably it differs only $1.7 \%$ from the original size of the ostrich egg diameter of c. $11.4 \mathrm{~cm}$ at the time of the casting of the Lenox globe (Missinne, 2013: p. 16). One soldi is one $20^{\text {th }}$ of the Florentine braccio of $58.32 \mathrm{~cm}$ which was the Italian standard Tuscan measurement ${ }^{51}$.

\footnotetext{
${ }^{49}$ I thank Kyle R. Triplett for his measurement and mails dated 16.11.2013 and 20.12.2013.

${ }^{50}$ For the reason of the remaining red patina of the copper of the Lenox I refer to nr. 3 in the printed letter to the editor, Col. Tom Sander, Letters to the Editor, The Portolan, Issue 91, Winter 2014, p. 3.

${ }^{51}$ Leonardo uses for example at the bottom of the Foglio of the Vitruvian Man the measurement of Palmus Minor (small hand palm), or 4 fingers. One and a halve Palmus Minor is equivalent of $11.16 \mathrm{~cm}$. As to the French measurement units used, the difference with 4 historical measurement units of France or French pouse applied in Albi $(2.722 \mathrm{~cm}$, which is, prior to 1668, 1/12th of an French Royal Foot of 32.66 $\mathrm{cm}$ ) amounts to $4.5 \%$. In contrast, the diameter of the Motus none Spere is $16.3 \mathrm{~cm}$ or exactly 6 pousse of Albi. The diameter of the Astrolabium Physicum is $17.2 \mathrm{~cm}$. Based on the Royal French Foot of Lyon of $34.2512 \mathrm{~cm}$ the Astrolabium Physicum measures exactly 6 pousse of Lyon. These measurements confirm that the French pousse was applied for both the Motus none Spere (Albi) and the Astrolabium Physicum (Lyon) instead of Italian measurements. The use of two different measurement standards from two different locations is not at all unusual as it was common to use the measurement standard of location where the work was executed. This detail shows that apparently L. Boulengier must have needed quite some time to prepare the layout for the engraver. It also may show that the order for the design may have occurred at a different time and location. I am inclined to think that he first worked on the Motus none Spere while still at Albi and subsequently on the Astrolabium Physicum while in Lyon, where presumably both were printed. I thank librarian Triplett for his kind mail regarding the results of the measuring at the NYPL dated 16.09.2014 and Dr. O. Cabayé for his mail 20.12.2014 confirming the size of the French pousse used in Albi early 1500. For the source of the French measurements I refer to Guilhiermoz (1913), De l'Équivalence des anciennes mesures. A propos d'une publication récente. Bibliothéque de l'Ecole de Chartes, 1913, Vol. 74, Numéro 74, pp. 276-279. http://www.persee.fr/web/revues/home/prescript/article/bec 0373-6237_1913 num 74 1 448498? Prescripts Search tabs1=standard\&
} 
The issue of Leonardo not having recorded the discovery of the New World has been the subject of debate. It was suggested that because he did not write about it, that he did not know. Upon meeting with the world leading expert, the Italian born American University Professor from UCLA, Prof. Dr. Carlo Pedretti in May and August 2014, at his private home, near Vinci, I asked him if Leonardo knew about the discoveries of a new world. I did this after showing him the reverse of Codice MS I 29v (world section divided in 4 parts, instead of 3 and the Ptolemaic projection of the old world) by Leonardo da Vinci, from c. 1494.

His answer was that there was no doubt whatsoever that any person living in Florence, so also Leonardo da Vinci, was very much aware of the widespread news of discovery of a newly found part of the world, so also about what a few years later would be called America, and that he was even influenced by $i^{52}$. Artists are generally the seismographs of the society and of the societal and cultural influences on the surroundings in which they live.

The drawing c. 1495 by Leonardo of a political caricature depicting the crowned Pope (Alexander VI) as an imperial symbol of Rome, on the shore of the Mediterranean Sea, standing on a terrestrial globe attracting the widespread corruption using the iconography in the form of a sailing wolf with an olive tree as a sailing mast is a clear example of societal seismography ${ }^{53}$. Upon my question, at the August $17^{\text {th }}$ meeting, at which his wife, my wife, and my son were present, if the Lenox Globe as a cast, and therefore the Ostrich Egg globe as its model could be attributed, based on amongst others the mathematical evidence (7000 miles as cited above) and the detailed artistic genre aspects he was adamant and stated... "Even much more than that".

It would not be the first time that a copyist benefited from the intelligence of this universal genius, and this replicating, handling Italian measurements, was reflected in the size of a globular map, issued only a few years later.

\section{Aesthetics of This Globular Map (CEGG), Its Unique Cartographic Aspects, Provenance and the Issue of the Transcription of the Wind Directions}

\subsection{Aesthetics of the Globular Copper Engraved Map}

The elegantly lettered capital letters (Bembo type) are applied without letter punches. The globular map furthermore shows inscriptions, coastal outlines, dots for cities (possible potential source of taxable income as animated by the decorator L. Boulengier), braided waves (Figure 1(C): Detail of waves), furious whirlpools, perilous and billowing seas (Lynam, 1960: p. 4) and rivers which appear like Aristotelian veins of water (Van Duzer, 2002: p. 121).

The graceful arched borders etc. are drawn in ornamental lines and show the genre history typical of Italian

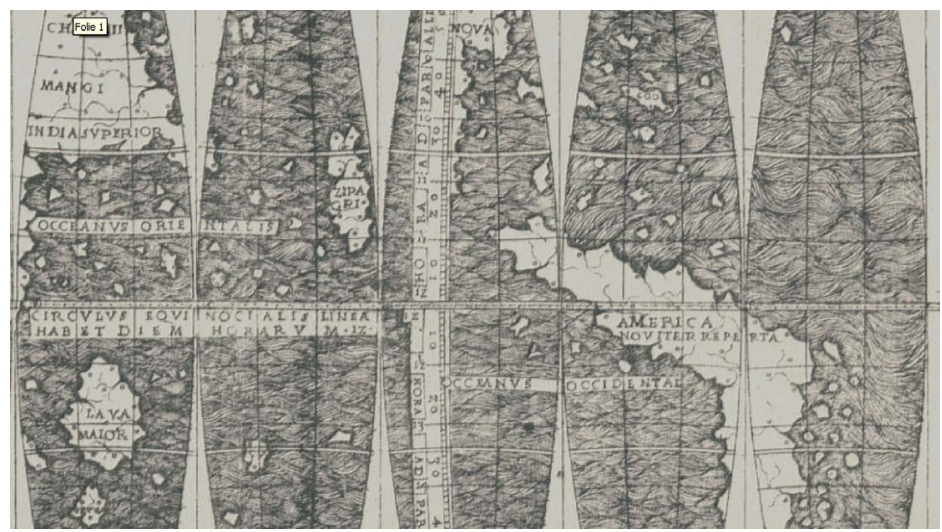

Figure 1C. Detail of waves.

\footnotetext{
${ }^{52}$ Personal comments by Dr. Carlo Pedrettion August $17^{\text {th }}$ 2014, at his residence near Vinci, Tuscany. Part of the content of Codice MS I 29 $\mathrm{v}$ was previously defined as "a sketch of a piece of textile"... In Cod. Leicester $26 \mathrm{v}$ Leonardo writes (crossed out) about speaking to a Genovese about the sea. In 1503 Leonardo writes about a Vespuccio and a book on geometry in Arundel $132 \mathrm{v}$. In Codice Atlanticus 331r from 1504 while in Florence, Leonardo writes: "his world map that he wants back from his friend Amerigo Benci". The Cosmography of Ptolemy is among his inventory of books in Cod. Madrid II 3 recto. In the Codice Arundel 191r a reference is made to a book of Maestro Paolo Physician, thought to be the book of Maestro Paolo Toscanelli who was also a Physician. In the royal collection in Windsor, a globular map with the name America on it was found inserted. It is believed that the manuscript map was drawn by his scholar Melzi c. 1515, using the design invented by Leonardo.

${ }^{53}$ Mail titled "Leonardo da Vinci RL 12496-Solution for the Iconography by Dr. Stefaan Missinne", dated 16.12.2013, from Martin Clayton from the Royal Collection Trust. http://www.royalcollection.org.uk/collection/912496/a-political-allegory
} 
Renaissance. From the early beginning, and as hatching is easy work for engravers, the coast-line of the continents etc. are marked by cross-hatching (Lynam, 1960: p. 4). Although the form of the globular map may suggest that it was the author's intention to glue the paper on the surface of a sphere, the fine ornamental border may indicate that otherwise.

A particular feature, namely the elaborate treatment of the seas has the greatest similarity to the first ever Italian printed copper engraved and rarest of incunabula Ptolemy world maps (Campbell, 1987: pp. 35, 129) ${ }^{54}$. The aforementioned uses a conical projection and is printed in Bologna 1477. This untitled world map is part of an atlas "Cosmographia" by Dominicus de Lapis which Germanus recensed ${ }^{55}$.

The positional little circular dots on maps to mark localities are, as stated by one of the world leading early map experts Dr. Peter Meurer, a critical innovation which characterises the work of Germanus (Meurer, 2007: p. 1183). On this map, these dots for geographical locations, presumably "cities" (or even abbeys) have the following geographical dispersion: $63(10 \%)$ for Europe, 162 (25\%) for Africa, $383(58 \%)$ for Asia and a bewildering $45(7 \%)$ for the newly discovered territories e.g. American continent. The latter may even have a futuristic evangelistic connotation.

The decorator, in this case L. Boulengier may have been influenced by his geometric studies and the possible eminent tax income wishes for the French King Louis XII for which he is known to have made prognostic studies (Cabayé, 2001: pp. 671-693).

The more cities (and/or abbeys) the more taxable income for example based on land measurement. The French King had taken over the reign of the Kingdom in 1515 from his big spending predecessor the King Charles VIII who had emptied the treasury. The Concordat of Bologna between the French King and Pope Leo X (1513-1521) gave him access to the enormous wealth of the French Church and solved "the issue of income", as he had been, in large part due to the high war effort and costs of the Italian wars, left "broke"

The genre history of this globular map is exemplified by the "fake exactitude" (Gautier Dalché, 2007: p. 404) which remind us of so called "horror vacuii" typical for Germanus. The latter, who was also an astrologer, was virtuous in filling up map space and even put trees on Greenland. A decorative detail of one of his maps (Durand, 1952: p. 17) particularly the way the red coloured curly "rivers" are drawn, I exclusively found on the map of Anglia and Hibernia Pars by Jacob D'Angelo. It is a manuscript map of Greenland and Scandinavia from the Geographia ${ }^{57}$ which is dedicated to Pope Paul II (1464-1471).

The intricate "rivers" that are typical for the above mentioned "horror vacui" appear like the decorative "rivers" that flow across this globular map. The aforementioned manuscript atlas, a treasure by the Benedictine Donnus Nicolaus Germanus (Donnus is an abbreviation of Dominus and stands for ordained clergyman), is now kept in the National Library in Warsaw (Galezwoski, 2013: pp. 20-21).

The above traces and the size of the map (likely intended for a globe with a diameter of c. $11.45 \mathrm{~cm}$ or c. 4 soldi) which in turn reflects the Tuscan braccio standard, unmistakably lead to an Italian (Tuscan) provenance and likely to D.N. Germanus in particular. The aforementioned worked in 1471 at the papal court in Rome.

According to Dr. O. Cabayé, French expert on Louis Boulengier, the latter never left France (Cabayé, 2001: Footnotes 67, 69). This also means he never came to Rome or to Florence. As this above mentioned Atlas is a manuscript atlas, this leads to the conclusion that it was either copied in Rome by a third party, or the layout left

\footnotetext{
${ }^{54}$ For the style and the hatching of the waves, the circular chimerical islands, the imaginary dots, and even the way IN (TE)RIOR is spelled. I refer to:http://gallica.bnf.fr/ark:/12148/btv1b550004419/f166.image.r=Cosmographia.langDE

${ }^{55}$ See the 1462 (1477) Bologna colored manuscript Atlas by Nicolaus Germanus in Munich (rar 124) formerly owned by Hartmann Schedel: http://bildsuche.digitale-sammlungen.de/index.html? $\mathrm{c}=$ viewer\&l=de\&bandnummer=bsb00032959\&pimage $=00191 \& \mathrm{v}=100 \& n a v=$ andhttp://bildsuche.digitale-sammlungen.de/index.html?c=viewer\&l=de\&bandnummer=bsb00032959\&pimage $=00192 \& \mathrm{v}=100 \&$ nav $=$ The edition of this Atlas at the National Library in Vienna (Austrian National Library) and the state Library in Munich are both complete. The world map is missing from the National Library in Paris.

${ }^{56}$ In 1516, the Concordat of Bologna signed between the Pope Leo Xth (1513-1521) and the French King Francis Ist gave the French King a unique privilege to appoint about 600 of the church office officials in France. He gained effective control over the church in France. It gave the French King and his successor's access to the enormous wealth of the French Episcopate. (Papal Bull Primitava 18.8.1516) The Concordat abolished the pragmatic sanction of Bourges from 1438.

https://books.google.at/books?id=2WuMyEzani8C\&pg=PA134\&lpg=PA134\&dq=concordat+Francis $+\mathrm{I}+$ and + Pope + Leo $+X \&$ source=bl\&ots =KyUfPNIMH3\&sig=xlcuQWR6KYTkkZggJA6V4frSQ-k\&hl=de\&sa=X\&ei=u-WTVMHKHYTkat DgegP\&ved=0CCsQ6AEwBA\#v=on epage \&q=concordat Francis I and Pope Leo $\mathrm{X} \& \mathrm{f}=$ false In a Fresco by Rafael and his pupils, depicting the coronation of the King Francis Ist in the Stanza dell'Incendio in the Vatican, the young kneeling king holds a terrestrial globe, without the usual cross on the orb. See also: Götz-Rüdiger Tewes and Michael Rohlmann (2002), Bram Kempers, Mohr Siebeck, Tübingen, 2002, p. 404

${ }^{57}$ Map Nr. XXX 3, cc. 87 v-88 r as depicted in Amerigo Vespucci, La vita e i viaggi, Sebastiano Gentile, Banca Toscana, Giunti, Milano, 1991, p. 26
} 
Tuscany by an Italian immigrant or a foreign "visitor" or the layout of the map by its author was personally taken and transported to France.

As the French were invaders of Northern Italy and had direct access to Renaissance treasures and documents, I believe the engraving, perhaps still in its layout form, was part of booty brought back by the French from Northern Italy during the Italian wars.

The German Renaissance humanist and "promoter" of the Italian Renaissance in Germany, Conrad Celtis (1459-1508) reports to have met with Germanus during his visit to Italy in 1486. The elderly Germanus bitterly complained about the glory and profit that were taken by others of his work "alius ex suis operibus tulisse honores". In this case it is his "Cosmographiae" which is newly printed (and partially newly edited) in 1486 by Johan Reger from Kemnat ${ }^{58}$. As I will show, he is not the only one who is going through this unpleasant experience of finding unauthorised copies.

\subsection{Unique Cartographic Aspects on This Globular Map (CEGG) (Compilation 2 CEGG vs. WC World Summary) (Compilation 3: Summary of Cartographic Details ${ }^{59}$ )}

On the globular map, North America bears the name "Nova" (part of modern Canada) while the South American Continent, which is separated from the north, bears the words "America noviter reperta", or in English "recently discovered America".

The cartographic imagery typical for a specific time and culture, reveals not only a technological development in copper globular map, but reflects a symbolic and cultural meaning (Mano, 1980: pp. 21-29).

The latitude notation is accomplished with great precision between the interval of $280^{\text {th }}$ and $290^{\text {th }}$ degree East, between Zipagri and "America Noviter Reperta".

Calicut is located to the West of Taprobana and Madagascar is below the tropic of Capricorn.

Upon comparing the globular map of the UB Munich, there seems to be no doubt that the woodcut globular maps were made by replicating the highly detailed globular map, but definite proof, at this stage is still wanting.

The comparison with the large world map which seems to be a logical step, did not offer any positive results.

To underline this statement, a few illustrations may suffice ${ }^{60}$ : The coast of Guinea is c. 10 degrees closer to the equator than on Waldseemüller's large world map. The line of the tropic of Cancer is south of Spagnola (Cuba).
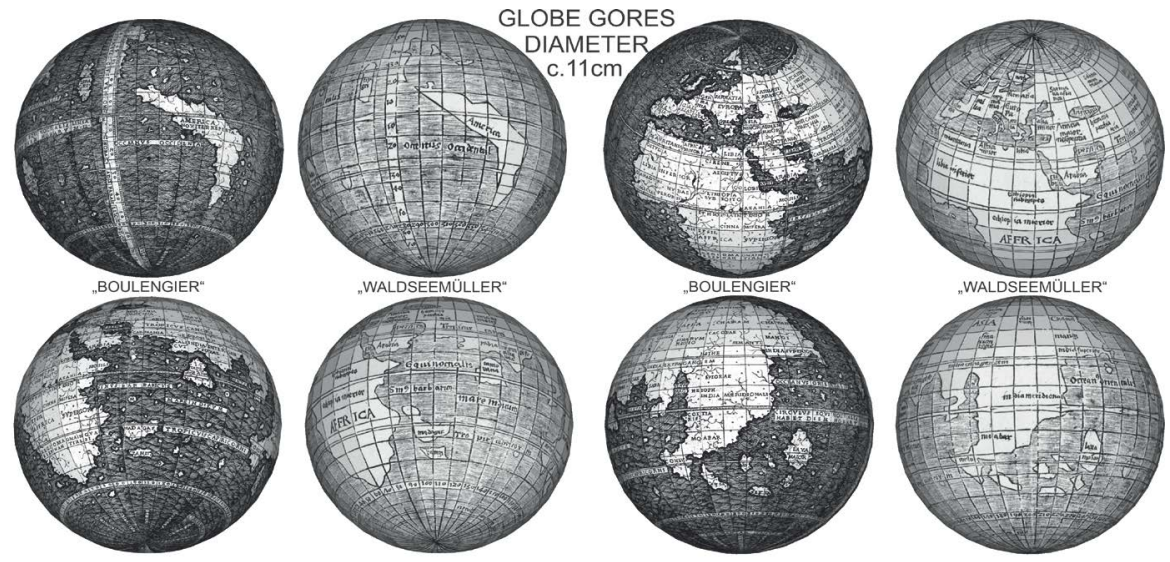

\section{Compilation 2. CEGG vs. WC World Overview.}

\footnotetext{
${ }^{58}$ Dr. P. H. Meurer op cit. p. 1183. He refers to Romuald Bauerreiß OSB, St. Bonifaz, Munich, "War der Kosmograph Nikolaus de "Donis" Benediktiner, in Studien und Mitteilungen zu Geschichte des Benediktiner-Ordens und seine Zweige, Verlag der Bayer. Benediktinerakademie, 1937, Vol 55, pp. 272-273.

${ }^{59}$ These assemblages were personally compiled in a Viennese Copy Shop with the assistance of a Philippine student in Architecture. In this Compilation 3 the Roman Numbers at the bottom stand for: I = Globular Map in Copper, II = Globular Woodcut Map from UL Munich (Cim 107-2), III = Globular Woodcut Map (4 other examples), IV = Insert of the Waldseemüller Reprint World Map c. 1516 at the LoC, IV $=$ Details from the Large Waldseemüller Reprint World Map c. 1516 at the LoC.

${ }^{60}$ There are, in contrast (see also 17. n) to what J. Fischer writes in 1907, clear differences in the indication of the degree of latitude and longitude of the large map and on the two insert maps. A few examples: a) The Equator leaves West-Africa on the insert map on the $10^{\text {th }}$ degree which is not the case for the large map. b) The Eequator on the insert map passes north of one of the 3 big lakes of the Nile, but passes through the same lake on the big map. 3) The Equator leaves the South American Continent on the large map on a different degree than on the small insert map. For the argumentation followed by J. Fischer and Fr. Von Wieser in 1907 we refer to the Cosmographiae Introductio of Martin Waldseemüller in Facsimile., US Catholic Historical Society, 1907, pp. 23-25.
} 
In contrast to the large world map where the location of the Tropic of Cancer is north of Spagnola (Cuba), the "so called coast of Florida" is not on this globular map, whereas this is the case on the large world map.

A few geographical names on this globular map have not been identified yet. This includes COD (only capital letters are used on the print) for a small island north of Isabella that may refer to "CONSECRAT, OFFERT, $D I C A T$ " or the Spanish catholic baptism of these unknown islands. Below the small island, a fishlike creature is depicted.

The following inscription is engraved at the bottom of the globular map: "Universalis cosmographie description tam in solido quem (sic) plano", which refers to a flat planiglobe projection but not to a globe, as erroneously interpreted in the CI by Ringmann. This inscription, with some misspellings, is an additional piece of evidence that Boulengier had access to the 1507 Cosmographiae Introductio printed in St. Dié, a topic on which I come back later.

\subsection{Provenance of This Globular Map (CEGG)}

The provenance of this intricate globular map is from a loose insert in an adapted but contemporary reprint of the second edition form April 1507 of Waldseemüller's CI. The adapted reprint is published without a date in the Colophon but with 1507 in the content.

Originally it was, thought to be from c. 1510. It is printed by Jean de la Place in Lyon and edited by Boulengier (Fumagalli, 1893: p. 209).

This globular map as mentioned was found together with 2 other loose copper engraved plates, both of which are also unsigned. One is titled: "Astrolabium Physicum" (Figure 4) and the other "Motus none Spere et trepvdacionis octave Spere 1514"61 (Figure 5), which forms the basis to define a horoscope ${ }^{62}$.

At the bottom there is a dedication in which he expresses his high esteem for Robertet. (For further details see Appendix 1). This text seems to have been added and perhaps printed separately as can be spotted from the difference in size and location of the extraordinary circular printing or screw marks ${ }^{63}$, of the elaborate "Motus none Spere" which concludes with "Artificio Lvdovici Boulegier Allebie 1514".

Boulengier writes in a dedicatory letter of his CI that he had noted other globes which had been previously published by others ${ }^{64}$. This very relevant sentence is missing in the CI by Waldseemüller.

In this single sentence, "auctam a ceteris globis ab aliis jamdudum in lucem editiss" or "other globes previously published by others" Boulengier indirectly confirms that this globular map erroneously attributed to him, is not his invention, but someone else's creation. He concedes the printed authorship of someone else and copied these letters A D G outside of the main picture on this globular map.

He fails to refer to a large printed map as the one by Waldseemüller.

Even, the Italian researcher Roberto Almagià is unsuccessful to include any extant globular maps from the early XVI century in his very detailed research (Almagià, 1951: pp. 27-34).

Pursuant to Harisse, "there is no evidence that this globular map and the other two plates were engraved at the same time" (Harisse, 1892: pp. 494-496). I tested Harisse on his statement statement and sound evidence. In addition to the fact that both the Astrolabium Physicum ${ }^{65}$ and the Motus none Spere have the date 1514 printed on

\footnotetext{
${ }^{61}$ The Trepidation of the eighth Sphere in Medieval Astronomy calculated the positions of the planets starting from the locations of the apogees assumed to be in the eighth sphere. See A companion to Astrology in the Renaissance, Edited by Brendan Dooley, Brill, 2014, p. 67-75 and E. J. Aiton, Peurbach's Theoricae Novae Planetarum: A Translation with Commentary, in Osiris, $2^{\text {nd }}$ series, Vol. 3 (Aiton, 1987: pp. 4-43).

${ }^{62}$ It consists of a very unusual representation of the eighth sphere. It basically has to do with a special kind of motion intended to justify the seeming shift of the equinoctial points: the eighth sphere - the one carrying the fixed stars-, has one added motion around a fixed point of reference, so that the final result is a path looking like an " 8 " which is laid down (the symbol of infinity in mathematics). In order to locate these points, the astronomers were in need of a fixed point of reference for the celestial system. As a consequence a ninth sphere, similar to the eighth, but unmovable, was conceived. These fixed points are visible on the print at the beginning of Aries and Libra, and the eighth sphere can move about 8 degrees in both directions. The two signs respectively on the eighth and the ninth sphere are slightly out of phase. A three-dimensional harmonic motion involving changing velocities is intended to be presented. I thank Dott Fabio Seller for his kind explanatory message from November $12^{\text {th }} 2014$.

${ }^{63}$ Confirmed in a personal e-mail by the NYPL librarian Kyle R. Triplett dated 22.06.2013

${ }^{64}$ Fiorino (1899), Sfere terrestri e celesti di autore italiano oppure fatte o conservate in Italia, Società Geografica Italiana, 1899, Roma, refers on p. 93 to "intaglio, rame or legno" and on p. 94 to inventory of F. Roselli of 1528 in which "Appamondo in palla cholorito di minore instampa, prezzo 2 lire" is listed. Page 94 in E.L. Stevenson, Terrestrial and Celestial Globes, New Haven, 1921, states on p. 64, based on Fiorini, that "it is probable that Francesco for his establishment printed globe gores".

${ }^{65}$ I thank Univ. Prof. Dr. K. van Cleempoel, who had never seen the engraving of the astrolabium physicum, for his personal comment from 28.12.2014 that until now it was thought that Gemma Frisius was the first ( 1556) to have invented and apply this kind of astrological depiction defined as an "Astrolabium Catholicum". See "Medici ac Mathematici de astrolabe catholico liber..." and Koeman (1980), The Astrolabium Catholicum, Revista da Universidade de Coimbra, Nr. XXVIII, 1980, pp. 65-76.
} 


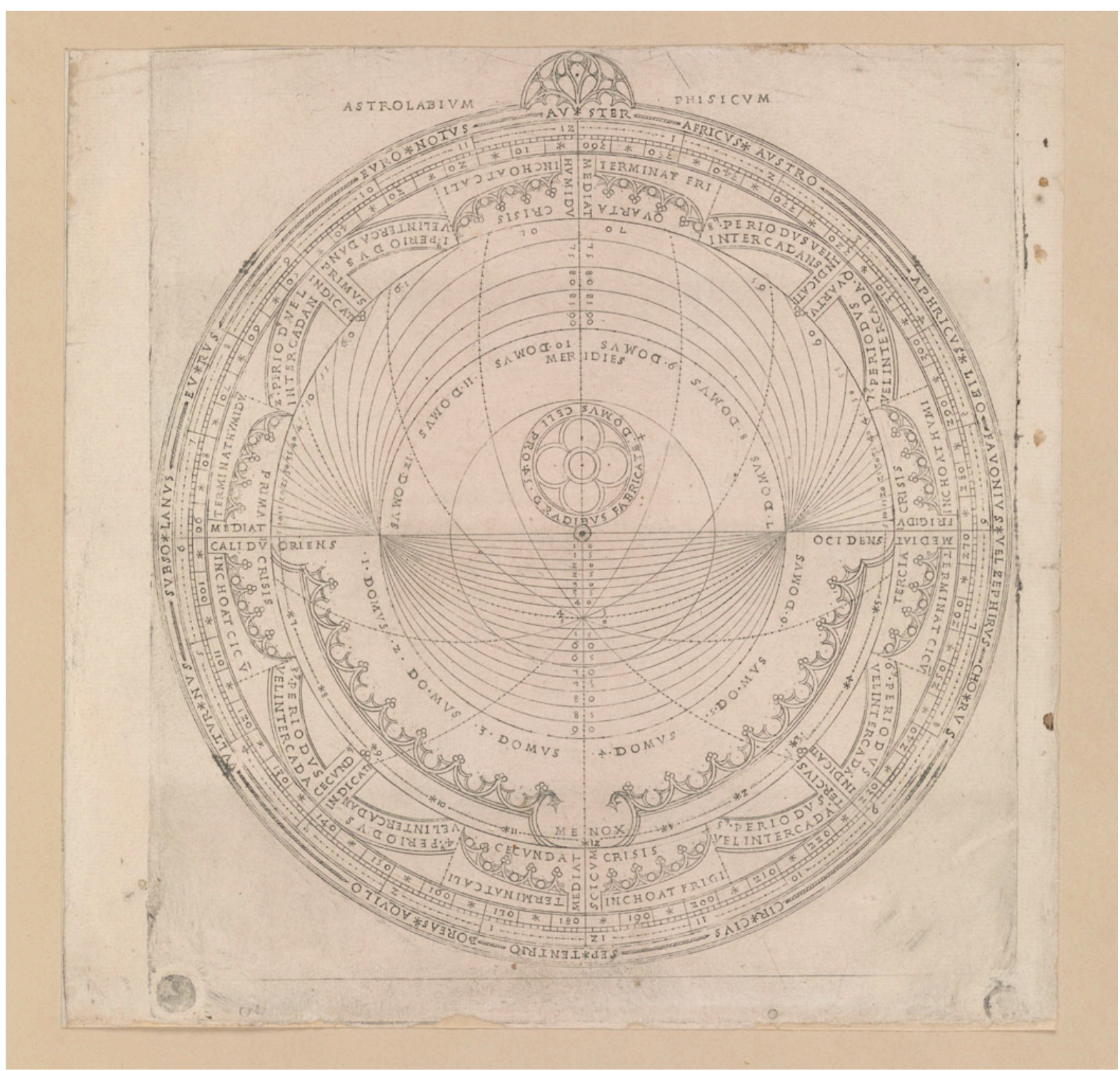

Figure 4. Astrolabium Physicum.

them even in abundance, there are visible left over traces of black color print from the printing process on the Motus none Spere.

The most likely source of these traces was the still wet print of the Astrolabium Physicum that was turned over on the engraving of the Motus none Spere prior to the complete drying of its ink. This finding may indicate that instead of a pile of prints, only one print was made ${ }^{66}$. This globular map does not have any of these color traces of wet ink (Figure 5).

\subsection{Transcription of the Wind Directions}

Table 3 is the transcription of the names of the wind directions on this globular map compared to the second April edition of the 1507 CI (Ringmann/Waldseemüller), the first edition of the Margarita Philosophica (1503, Fribourg) and the 1477 Ptolemy world map printed in Bologna, compared to the wind directions on the Motus none Spere c. 1514 (Woodward, 2001: p. 266).

\footnotetext{
${ }^{66}$ I thank Lafreri map expert Pierre Dumolin for this comment during a visit of the Expert on Astrolabes Prof. Dr. Koenraad van Cleempoel in Antwerp, December $28^{\text {th }} 2014$.
} 


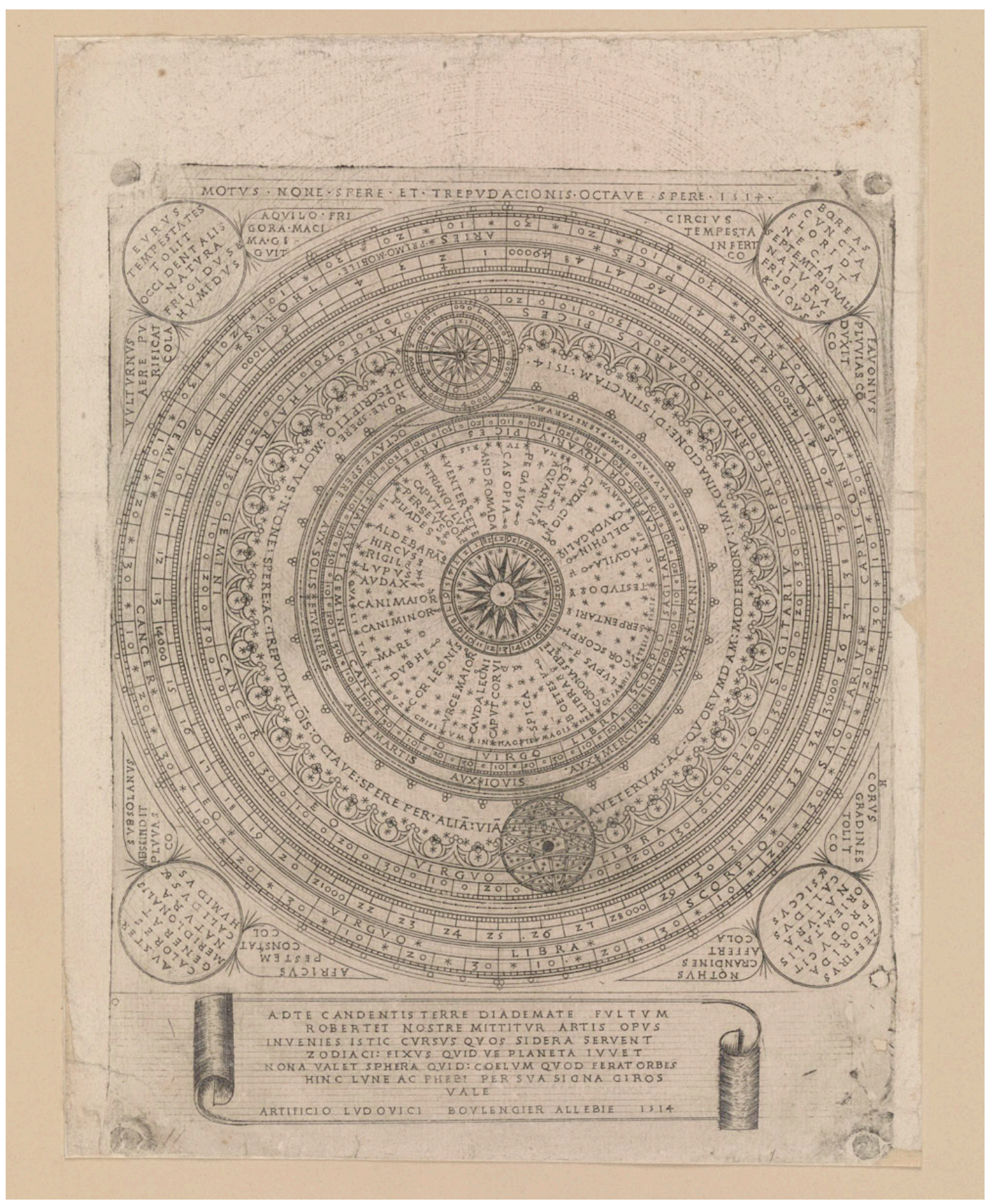

Figure 5. Motus None Spere.

The detailed comparison, using the method of the text criticism, of the nomenclature between the aforementioned and this globular map offers evidence that the globular map and the Motus none Spere have no common roots. The two latter prints were seemingly engraved at a different time and they could have had different authors. Most likely they had one decorator namely the diligent, assiduous and likely careerist Louis Boulengier.

Apparently there was no printing facility in Albi between 1484 and 1670 (Cabayé, 2001: pp. 671-693). I think 
the globular map may have been printed consecutively in Lyon by a travelling printer ${ }^{67}$ or by a Tuscan printer living in exile in Lyon. The aforementioned may not have been uncommon French paper was used.

The copper engraved printing in Lyon only started as late as 1517 by Jean Duvet, who never printed in Albi ${ }^{68}$. The basis for this globular map is an Italian cartographic source for the world map. A Lower German (Dutch) expatriate living in Italy and France is the source for the Motus none Spere and Astrolabium Physicum.

Until now, nobody questioned if it had any meaning that these three were found together. I think this is quite relevant. Lacking to consider their differences in style and content is like forgetting to inspect the back of a painting, in order to learn more about the history of the painting.

\section{Essential Historical Cultural Background}

The name ROBERTET ${ }^{69}$ without a first name is indicated in the dedication at the bottom of the Motus none

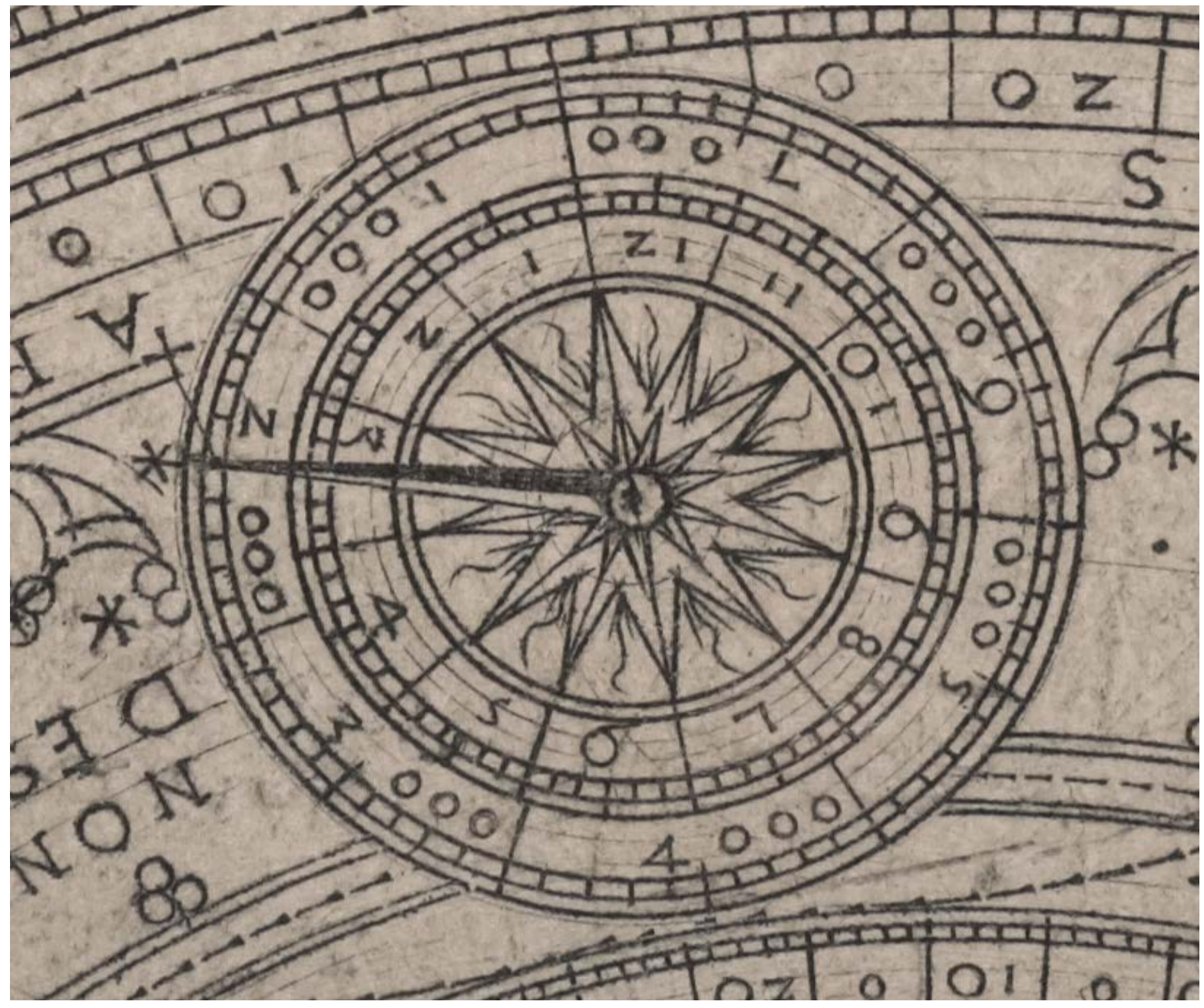

Figure 5B. Detail Motus None Spere.

\footnotetext{
${ }^{67}$ According to Director Piere-Antoine Lebel (Mail from 24.11.2014) from the Printing Museum of Lyon, this was not at all an uncommon practise. Lyon was an important city on the crossroad between Venice and Paris, Basle and the Low Countries. French printers like Nicolas Janson went to Italy, and the Italian printer Baldassare de Gabiano arrived in Lyon in 1497.

${ }^{68}$ I thank the French printing expert Pierre-Antoine Lebel from the Printing Museum in Lyon for his mail from the $25^{\text {th }}$ of September 2014.

${ }^{69}$ The Family Robertet has a family grave chapel in Montbrison, which is situated on the $45.36^{\text {th }}$ parallel. The patron of the Chapel is the Holy St. Michel after the patron of the roman-catholic chivalric royal order of Saint Michel founded by the King Louis XI of France in 1469. The father of Florimond de Robertet, Jean II Robertet (1405/1420-1492), worked for the French Kings Charles VII, Louis XI \& Charles VIII). I thank genealogy expert Mr. Etienne Pattou for his mail dated 7.12.2014. Florimond Robertet had an uncle named Jacques Robertet from the religious order at the Isle Barbe and a younger brother named Jean Robertet. http://racineshistoire.free.fr/LGN/PDF/Robertet.pdf
} 
Table 3. Transcripition of the wind directions on the engraved globular map versus contemporary sources.

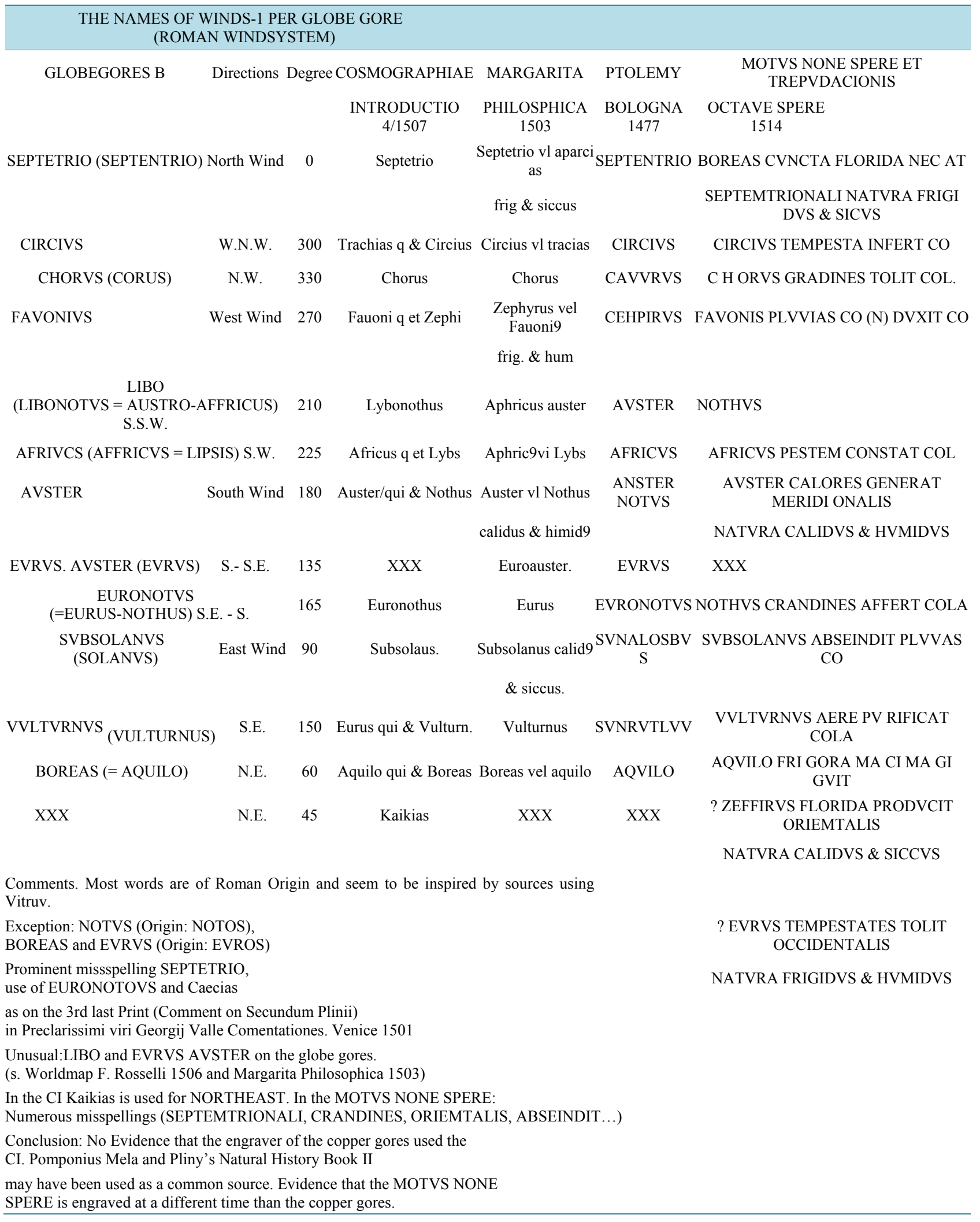

Further reading: Naomi Reed Kline, Maps of Medieval Thought, p. 9. 
Spere, with the date 1514. The CI mentioned above, is thought to be dedicated to Bishop Jean-Jacques Robertet of Montbrison ${ }^{70}$.

He was Bishop only for a short interval of 6 months between November $22^{\text {nd }}$ of 1517 and May $26^{\text {th }} 1518$. So why is the date of this globular map conjectured to 1514 , one would ask?

The Robertet family was a very influential family at the court of the King of France and they were "sponsor" of L. Boulengier (Cabayé, 2001: Footnote 52).

The "Motus none Spere" does not make allusion to Jacques Robertet or to his brother Charles Robertet (Tewes \& Rohmann, 2002: pp. 6, 547) (11 $^{71}$ Professor in Theology, and Roman Catholic Archbishop of Albi, for an interval period of 2 months from March 1515 to Mai $1515^{72}$, but to a much more influential member of the Robertet family. In what follows, I show that Albi seemed to be a very crucial "step stone" on the road to Rome, even for the Medici. ${ }^{73}$ Even Robertet had acknowledged that many cardinals thought more about bishoprics than of the reform of the church... (Setton, 1994: p. 95).

The predecessor of Charles Robertet is Cardinal Jules de Medici (1513-1515), nephew of the powerful Medici Lorenzo the Magnificent. Jules became Cardinal in 1513 with the help of his family member Giovanni de Medici, (he was only thirteen when he himself was appointed cardinal). Jules later became Pope Leo X. Giuliani became Pope Clement VII ten years later (Unger, 2008: p. 327) ${ }^{74}$.

Jules de Medici was preceded by Cardinal Robert Britto Challand de Gubé (1510-1513) and by Cardinal Louis II d'Amboise (1473-1510), patron of the arts, who became, at the age of 28, Cardinal by Pope Julius II (Giuliano della Rovere ${ }^{75}$ ) in $1506^{76}$.

Those who did throw in their lot with the Pope prospered (Unger, 2008: p. 285) or relatives of a reigning pontiff or powerful cardinals like George II d'Amboise (Gaggetta, 2013: p. 288) were automatically vaulted into the first rank of the European nobility (Unger, 2008: p. 241). Both characteristics applied to cardinals of Albi, many of them who were nonresident ${ }^{77}$.

In 1502 Bishop Louis II d'Amboise accompanied the French King Louis XII during a military campaign in Northern Italy. In 1507, Louis II d'Amboise accompanied the French King Louis XII to Italy for a second time. In April 1507, they were being received triumphantly in Genoa (birthplace and "home republic" of the warrior Pope Julius II!).

He attended the peace negotiation conference amongst others which is chaired by the French King Louis X, King Fernando II of Aragon and Castile at the strategically chosen location of Savona. King Louis XIIth returned to Lyon on July 17, 1507 (Pins, 2007: p. 87) and I may assume accompanied by Louis II d'Amboise.

The aforementioned is the birthplace of the authoritative Italian who turned cardinal at the age of 17, patron of the arts, diplomat Raffaele Riario (1460-1521), nephew of Pope Sixtus IV (1471-1484) and relative of the later Pope Julius II (1503-1513) (Pendergrass, 2007: pp. 78, 88).

I presume that it was the Cardinal of Albi Louis II d'Amboise (1503-1510) known for his taste of Italian Renaissance (Gaggetta, 2013) who, during his stay in Italy in April of 1507 had access to the cartographic production of the map engraver Donnus Nicolaus Germanus, and acquired the drafts for this small globular map or transported French war booty ${ }^{78}$, on this return from Italy to Albi.

\footnotetext{
${ }^{70}$ Cédric Michon, Une ville contre son seigneur. Albi dans la première moitié du XVIe siècle, Université du Maine, CERHIO-UMR 6258, Cahiers du CRHQ no 1, 2009, p.6.

${ }^{71}$ Charles Robertet was preceded by Louis II d'Amboise, (1477-1511) Bishop of Albi After failing to become Pope in 1503, another important and powerful family member of the Amboises, Cardinal Georges d'Amboise (1460-1510), uncle of the aforementioned, was rewarded with the wealthy comptat Venaissin which includes the area of Avignon and the city of Carpentras.

${ }^{72}$ According to another source it was Charles Robertet who upon the initiative of his brother Florimond de Robertet, and thanks to intervention of King Louis XII was elected in December 1510 and took possession of the Episcopal seat of Albi on July $15^{\text {th }} 1511$ in Biget (1994), Sainte-Cécile d'Albi: Peintures, Toulouse 1994, p. 166 and a personal mail by J. L. Biget dated 2.11.2014.

${ }^{73} \mathrm{~A}$ map of France for daily use in the possession of the Medici since 1484 is mentioned on p. 138-139.

${ }^{74}$ Unger (2008), Magnifico, The Brilliant life and violent times of Lorenzo de'Medici, Simon \& Schuster, 2008, NY, p. 327.

${ }^{75}$ Giuliano della Rovere, at the early start of his steep career became cardinal of Carpentras in December of 1471 ...by a family member Francesco della Rovere (Franciscan Pope Sixtus IV) and met with Guillaume de Carpentras, astrologist and instrument maker, by origin from Wissekerke in Zeeland.

${ }^{76}$ www.catholique-tarn.cef.fr/ and www.catholic-hierarchy.org/diocese/dalbi.htlm

${ }^{77}$ I thank Dr. O. Cabayé for his comment dated December 23rd 2014 on this non residency aspect of the cardinals. This aspect has been overseen in the course of the research on the CI printed in Lyon.

${ }^{78}$ For valuable texts, including maps, manuscripts and limited volumes being transported as booty, to fill up French court libraries, from Renaissance Italy to France I refer to Knutsen (1999), The rise and Fall of World Orders, Manchester University Press, 1999, p. 15. and Sider (2005), Handbook to life in Renaissance Europe, Oxford University Press, 2005, p. 147
} 
A possible source could have been his powerful nephew and French Governor of Milan, Charles II d'Amboise (1473-1511), who in 1507 had suppressed a revolt in Genoa.

As the name "ROBERTET" in the dedication at the bottom does NOT have a first name, but refers to "ARTIS OPUS" and because of the proximity of Boulengier to the secretary of the French king Louis XII (Bacquet \& de Ferriére (1744)), this refers, as confirmed by P. Pithou (1582-1613) ${ }^{79}$ to the more powerful and art loving bibliophile, ambassador, treasurer of Louis XII and of Francis I King of France (1494-1515), Florimond I ROBERTET d'Alluye (1458-1527) ${ }^{80}$.

The aforementioned served three French Kings: Charles VIII, Louis X and Francis ${ }^{81}$ and had the order of Louis X to attract Leonardo da Vinci to France.

This is supported by Dr. O. Cabayé, the expert on L. Boulengier, who refers to the Manuscript du Fonds Dupuis no. 838, fol. 167 in which the proximity of the family ROBERTET to the king is the likely explanation for a royal command regarding a measurement calculation with a purpose of a tax reform, c. 1514, by the geometer L. Boulengier (Cabayé, 2001: Footnotes 10,16,18). Most certainly did the proximity to the French king have a key effect on the ecclesiastical careers of his two brothers Charles and Jacques. This is supported by the French Historian J. L. Biget.

The Date 1514 is quite compelling for the history of French royalty.

It is the year of the wedding of French King from the House Valois-Orléans, Louis XII, still without a male heir $^{82}$, with the very young Mary Tudor, Sister of Henry VIII of England in Abbeville.

Due to the Salic law, it was the final attempt, after having witnessed 1 male stillbirth (1500), 2 miscarriages (between 1505 and 1509), and 2 mortal male infants $(1503,1512)$ to have a male heir to the throne of the Kingdom of France. This tragically failed. King Louis XII, died on January $1^{\text {st }} 1515$. This signified the end of the House Valois-Orléans. The next French king was Francis I from the House Valois-Angoulême.

Upon having mentioned Albi in several instances in the preceding part of this text, I present the rather surprising find of a miniscule architectural detail on a copper print.

\section{Architectural Detail in the Tracery of a French Cathedral, a Partial Watermark and Artistic Style}

\subsection{Architectural Detail in the Tracery of a French Cathedral in Albi}

At the onset of this research, and although it may start to sound like a fictitious aspect compared to the Da Vinci Code, I sensed that the decorator of the "Astrolabium Physicum" aspect from his immediate surroundings and his hometown for his intricate design. He must have invested an enormous amount of time in these works. Actually, a small detail of the print of that mater namely the uniquely drafted but inconspicuous throne (the hanging feature) on the top of the engraving drew my attention.

This led to the idea that the Renaissance art for which the cathedral of Albi, icon of the military victory of Pope Innocent III (1198-1216) over the Cathar Crusade (1209-1222) and sometimes compared to a military fortress is worldwide known, might have inspirited the "ARTIFICIO" (i.e. Artifact), Boulengier.

Indeed, after $1 \frac{1}{2}$ years of research and after comparing numerous architectural details of so many cathedrals, which was like searching a needle in a haystack, this could be confirmed. A small but rather powerful part of the whole enigma was finally found.

The gothic flamboyant detail of the unusual throne on top of the Astrolabium Physicum (Figure 4(B)) led to the intricate pair of openings adorning the top of the double door below the center of the jube of the famous symbolic cathedral of Albi.

The jube, a more or less open tracery of wood or carved stone, typically a partition between the chancel and the nave, is a common feature in late medieval church architecture.

\footnotetext{
${ }^{79}$ The French text reads "Extraict d'un rollet aultrefois imprimé, en l'an 1514, par Loys Boulengier d'Alby, et dédié et envoyé à Monsr Robertet, secrétaire d'Estat.... Copy by P. Pithou, fonds Dupuis No 838, fol. 167.

${ }^{80}$ It is the French King Francis I who invited key Italian Renaissance Artists including Leonardo da Vinci to come and bring their artistic and specifically military knowledge including ballistic and geographical to France.

${ }^{81} \mathrm{He}$ married in 1504 the wealthy and much younger Michelle Gaillard de Longjumeau.

${ }^{82}$ Charles Pinot Duclot, op cit. p. 25 and a citation of the Medical Doctor Salomon de Bombelle.

${ }^{83}$ There is one example (Cat. Nr. 57-84/176) from the J. A. Billmeier collection in the Museum of History in Oxford dating to the XVth Century. I thank Dott. Fabio Seller for his kind mail dated October $23^{\text {rd }} 2014$.
} 


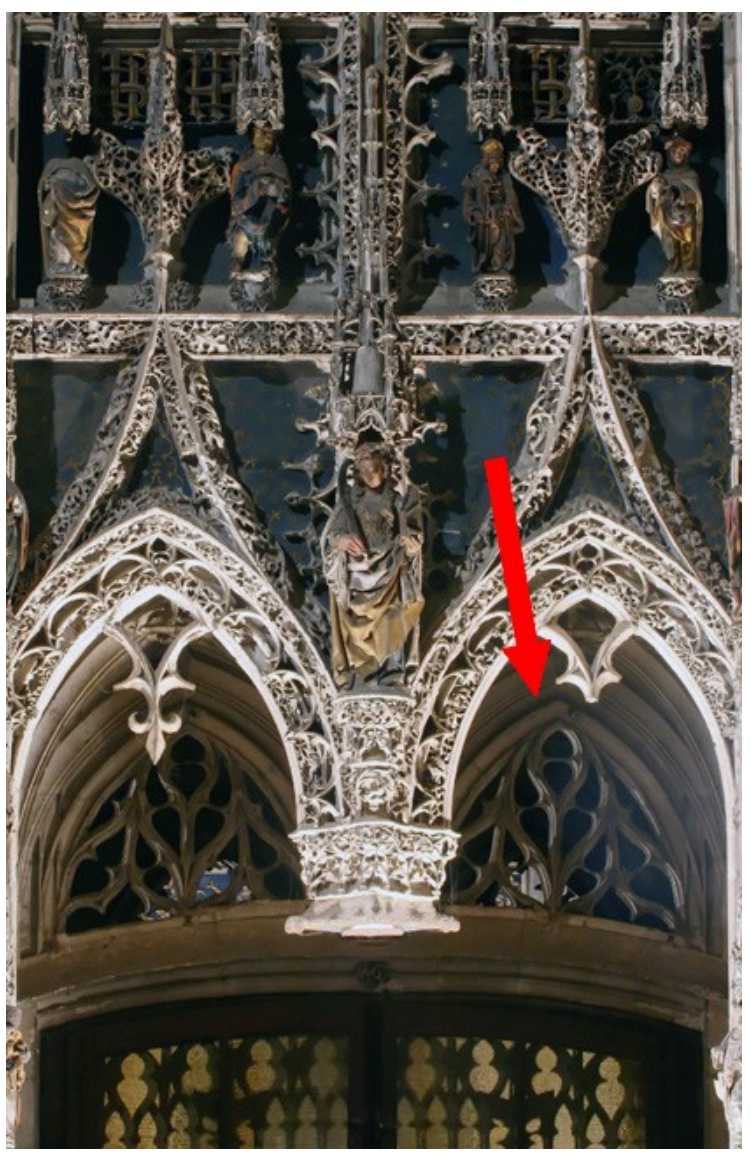

Figure 4B. Detail of the Jube of the cathedral of Albi.

Upon asking Dr. Olivier Cabayé in Albi ${ }^{84}$ who lives in Albi to test my hypothesis that the artist may have copied a detail from the cathedral of Albi, Dr. O. Cabayé came back to me by mail and confirmed that the throne of the astrolabe and the detail sculpting of the jube of the cathedral are as close as close as twins. (Figure 4(B):

\section{Detail of the Astrolabium Physicum versus Jubé)}

In other words, for his decorative work, Boulengier drew inspiration by the design of the stone cutting of the jube in the cathedral of Albi. The jube of Albi is world famous. It was constructed in 1500 under the supervision of the Bishop of Albi Louis I of Amboise (1474-1503) (Crozes, 1873: p. 73) who was the counselor and chamberlain of the French King Louis XII of France. (1462-1515). As already remarked, the successor of the aforementioned namely Louis II of Amboise may have been the missing link of the association of the Italian source for the layout of the map and the French decorator.

Boulengier, who is neither a physician nor astrologer, is the decorator of the Motus none Spere, the globular map and the Astrolabium Physicum, but he is not the inventor, otherwise there would be "invent" next to his name.

No other extant early XVI century globular map in the world than this one has this clear decorative pattern.

It leads to the idea that the person who invented this globular map was not a fastidious geographer, but rather a religious, philosophic decorative Renaissance artist, who located cities and rivers on unknown shores, in line with Ptolemy's Ecumene as on the 1482 world map by Donnus Nicolaus Germanus ${ }^{85}$.

\subsection{The Discovery of a Partial Watermark}

This globular map is printed on the same material (line rag laid paper with visible chain lines) as the copper en-

\footnotetext{
${ }^{84}$ Mail from Dr. O. Cabayé 1.6.2014. For the jube I refer to http://upload.wikimedia.org/wikipedia/commons/3/33/Nave of the Ste Cécile Cathedral - 2014-02-22.jpg?uselang=fr

${ }^{85}$ http://upload.wikimedia.org/wikipedia/commons/3/3c/1482_Cosmographia_Germanus.JPG?uselang=de
} 
gravings of the Motus none Spere $(23.4 \mathrm{~cm} \times 18 \mathrm{~cm})$ (with a cut off partial watermark $21 \mathrm{~mm}$ high) and the Astrolabe Physicum $(19.6 \mathrm{~cm} \times 18 \mathrm{~cm}$ ) (no watermark) with which they were found together, and which are unique in the history of science.

I think the layout (drawing) of this globular map is from a different person than the two added ones. L. Boulengier is the decorator, but not the inventor. This is supported by Univ. Prof. Dr. Owen Gingerich ${ }^{86}$ and Dr. Peter Meurer ${ }^{87}$.

As to the partial watermark on the copper engraving of the Motus none Spere, this consists of a water mill wheel with the teeth of the wheel directed counter clock wise and a handle type crank, i.e. wheel of torture, after the Holy Catherine and leads to a variant of Lyon. Briquet: 13.452, Lyon 1500-1503. Identical variations: Lyon: 1499-1501 and Le Puy: 1500, part of the group Briquet 1466/1503 ${ }^{88}$. In other words, the source of the paper is French, most likely from the early XVI century, but there is not a $100 \%$ concordance due to the fact that it is only a partial watermark, and so only of limited corroboration.

\subsection{Artistic Style, Religious Iconographical Aspects and the Orientation to the East of This Globular Map (CEGG)}

The above mentioned artistic aspect is particularly momentous as details for example of the medical astrolabe clearly reflect the French Gothic Flamboyant Style with the typical curvilinear elaborate tracery and trifoliate. The globular map does not have the elaborate tracery, only shows arches with the trifoliate, Florence's perennial symbol (Carpetto, 2001: p. 29) ${ }^{89}$. This trifoliate seemingly leads to Florence as the geographical source for the layout of the globular map. It may add substance which is, as proven earlier, supported by the use of Tuscan measurement sizes. The use of a paramount catholic religious symbol of the trifoliate does confirm the religious background of its decorator and likely of its Benedictine creator.

The epitome of the French flamboyant art is in the interior of the cathedral of Albi

(www.cite-episcopale-albi.fr). The style is known for the Rosettes of Gothic French cathedrals. One symbolically important French cathedral, with its two large towers appears like an elephant from a distance (Peyrat, 1870: p. 276), is part of the world heritage sites, and is in the centre of the wealthy diocese in Albi.

So it is a logical consequence that the artistic designer was influenced by the very rich artwork ${ }^{90}$ in his immediate religious surrounding and wanted Albi, his hometown, to be part of history.

In the Christian doctrine, the principle of the orientation is based upon the light. In accordance with Genesis II- 8 the worldly paradise is located in the East.

The principle orientation of the cathedral of Albi is toward the East and there are 12 side chapels on each side, as there are two times 12 arches on this globular map. The 1-12 numbered gores are also oriented towards the East $^{91}$ and the Climate Line is situated at 280 degree line. It is as if the engraver wanted to indicate that the Climate Line was the Jube... and the remaining 80 degrees lay beyond the known ecumene, namely the worldly paradise, thereby incorporating this historically far-reaching Christian aspect. He names the Ocean to the West of America, Occeanus Occidental ${ }^{92}$, after where the sun sets, or West.

The painting of the Italian influenced Renaissance fresco in the cathedral of Albi was completed in 1509, at

\footnotetext{
${ }^{86}$ Owen Gingerich, author of Astronomical Paper Instruments with Moving Parts, in Making Instruments count: Essays on Historical Scientific Instruments Presented to Gerard L'Estrange Turner, ed. R. G. W. Anderson, J. A. Bennett and W.F. Ryan, Alderschot, Variorum, 1993, p. 63-74.

${ }^{87}$ Personal mail from Dr. P. Meurer, dated 21.07.2013.

${ }^{88} \mathrm{I}$ thank Dr. Ezio Ornato, leading watermark expert, for this personal mail dated May $1^{\text {st }} 2014$. www.ksbm.oeaw.ac.at/ scripts/php/loadRepWmark.php?rep=briquet\&refnr=13452\&lang=fr

${ }^{89}$ Trifoliate or „Three obovate leaflets“ refer to the Trifolium pratense (red clover). It is one of the first plants ever cultivated by man and it is used to make a sweet herbal tea, with vital medical properties (antibiotic, blood purifier etc.) The iconographic symbol is used to depict the trifurcated balance of the Christian Trinity: the Father, the Son and the Holy Ghost

${ }^{90} \mathrm{Analog}$, it is possible to deduce that the woodcuts may have found inspiration by the protestant motivated artists, since they were created after 1517, the date of Luther his announcement of the 95 theses. The naming of "Engeland" on the so called Apian Globe gores, could have found inspiration by people wishing to flee the catholic European mainland.

${ }^{91}$ This orientation towards the East from this prototype model is a characteristic for other terrestrial globular maps, such as the woodcut ones discussed in this article. But in supplement they also stirred the ones (for a c. $11 \mathrm{~cm}$ globe gore) attributed to Apian (c. 1528). Even more than a 100 years later, the very uncommon French copper engraved globular map "Recens et integ orbis description 1610" made by Nicolvs SPIRINX (Dijon) kept at the Newberry Library (Novacco 2F 10) keeps this form, scale and size $(17.6 \mathrm{~cm} \times 35.5 \mathrm{~cm}$ ), style and layout for a $11.3 \mathrm{~cm}$ globe (12 gores) of the prototype mentioned. For the layout of the cathedral of Albi: http://upload.wikimedia.org/wikipedia/commons/9/9b/Plan.cathedrale.Alby.png?uselang=fr

${ }^{92}$ Occidentalis and Occide have the same Latin root. "Occide" means to slaughter or to kill. "Thou shalt not kill", as in the Ten Commandments (Exodus 20:13), the symbolic meaning of the perennial Sin.
} 
the same time when the cathedral was fully completed. This was during the period of the above mentioned all powerful Cardinal Louis d'Amboise II.

The catholic religion at the time of the Italian Renaissance which had arrived in France clearly influenced the design of the copper engraved plates. Particularly the architectural design of the cathedral, and the double row of chapels influenced the design of the world map. The two other prints show a rich flamboyant gothic impression, characteristic for the splendid and unique artwork of the interior of the cathedral of Albi.

The style of the globular woodcut maps omits any kind of elaborate flamboyant decoration, as if a certain type of protestant impression was intended, thereby probably confirming the later timing of their printing. Even the duplication of the nomenclature was selectively fashioned on the woodcuts.

As stated by Dr. P. Meurer, the influence of the "reformed thinking" on contemporary map making in Germany and the changed attitude e.g. the tool for educational purposes was enormous (Meurer, 2007: p. 1208).

But that leads to the question: What do a Motus none Spere, an Astrolabium Physicum and a globular map have in common?

\section{Transcription and Strong Evidence Leading to the Oldest Copper Engraved Globular World Map c. 1507 and America's Original Birth Certificate and a Certain Key Phrase}

\subsection{Transcription of the Nomenclature: Applied Stemmatics}

Table 4 depicts the transcription of the globular map (CEGG) which has a rich nomenclature with a total of 95 geographical place names including Ptolemaic, ancient tribes and other connotations. Although the nomenclature is far richer, the first impression is that the ones on this more detailed globular map perfectly match with the woodcut ones as Gallois noticed in 1892.

In view of the richness of the nomenclature, the copyist did not add any additional geographical toponym to "his compilation". In cartography this "matching of the same place on a map" is a unusual phenomenon, as cartographic names are usually relocated based on more recent and sometimes "new" available source of information.

Based on the Textual Criticism Method (stemmatics) developed by Karl Lachmann (1793-1851) and the ex-

Table 4. Textual comparative analysis: yellow means failing nomenclatura, green means accordance, red means misspelling.

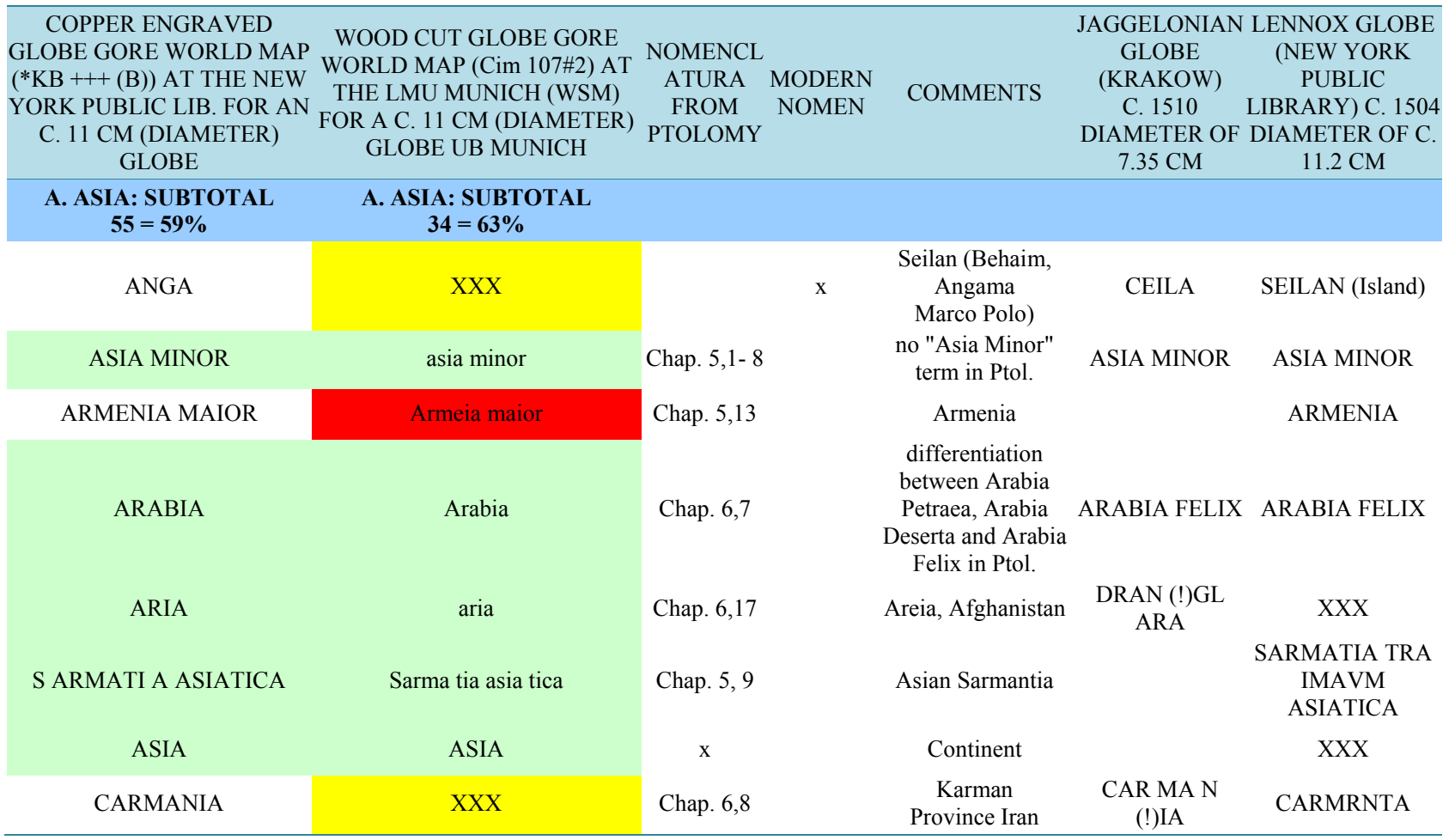




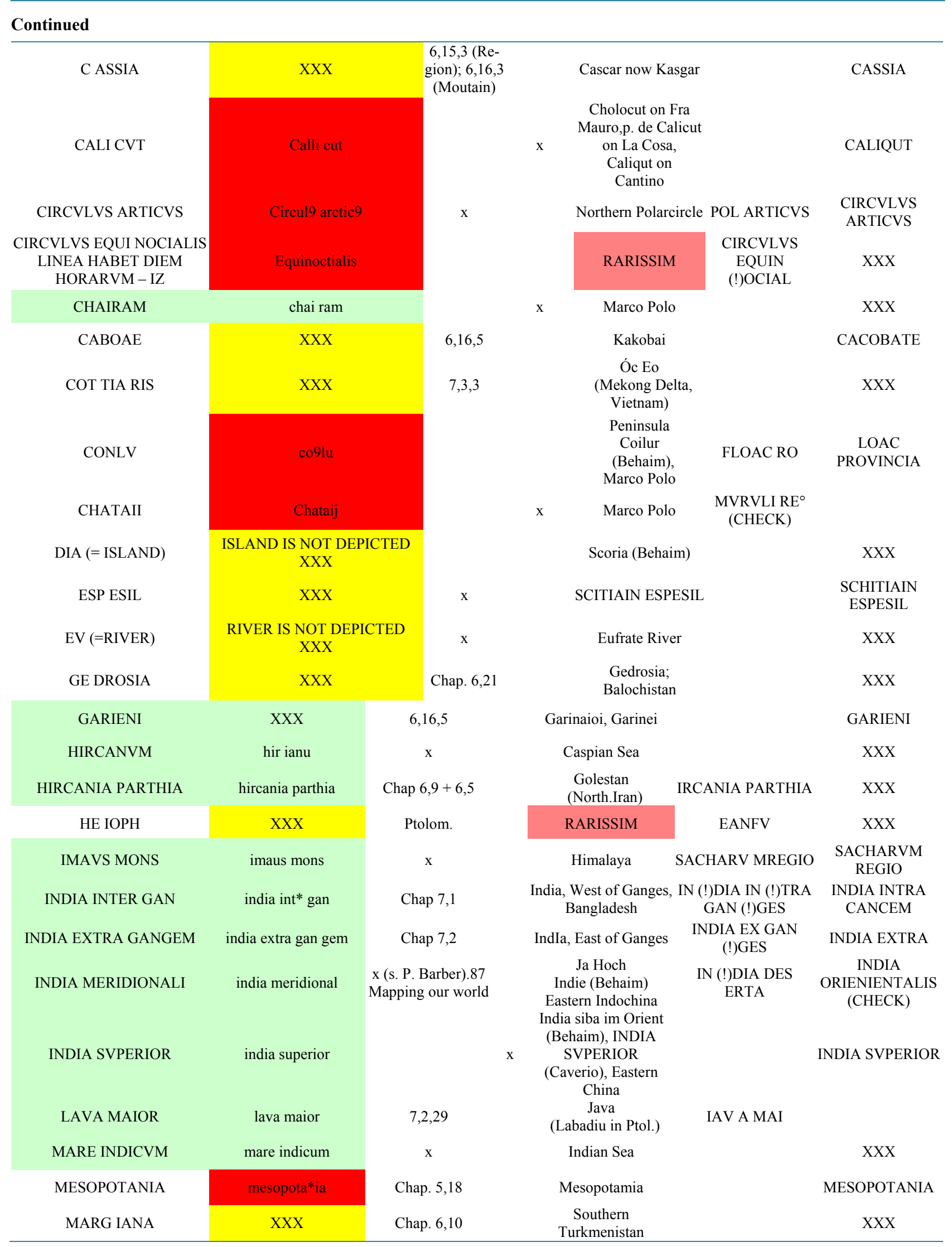




\begin{tabular}{|c|c|c|c|c|c|c|}
\hline \multicolumn{7}{|l|}{ Continued } \\
\hline MO ABAR & inoabar & & $\mathrm{x}$ & Maabar (Behaim) & MOA BAR & MOABIA REGNO \\
\hline MANGI & mangi & & $\mathrm{x}$ & Ciangli (Behaim) & CIANGI & $\mathrm{XXX}$ \\
\hline OCCEANVS ORIE NTALIS & Occean9 Orien talis & & $\mathrm{x}$ & $\begin{array}{l}\text { Oceanus Orientis } \\
\text { Indies (Behaim) }\end{array}$ & $\begin{array}{l}\text { OCEANVS IN DICVS } \\
\text { MERIDIONALIS }\end{array}$ & $\mathrm{XXX}$ \\
\hline PERSICVM & persi c. & $\mathrm{x}$ & & $\begin{array}{l}\text { Sinus Persicus } \\
\text { (Persian Gulf) }\end{array}$ & $\mathrm{XXX}$ & XXX \\
\hline PEVTA & $\mathrm{XXX}$ & & $\mathrm{x}$ & Java Minor (Behaim) & PEVTA & $\mathrm{XXX}$ \\
\hline SABA & $\mathrm{XXX}$ & $6,7,42$ & & Myanmar & & $\mathrm{XXX}$ \\
\hline SCHITIA INTRA IMAUM & Schitia intra imaum & Chap. 6,14 & & Part of Kasachstan & SITHIA & $\mathrm{XXX}$ \\
\hline SACCE & $\mathrm{XXX}$ & Chap. 6,13 & & $\begin{array}{c}\text { Saka } \\
\text { (Old Persia) }\end{array}$ & PERSIA & PERSIA \\
\hline SCHITIA EXTRA IMA VM & Schi tia ex tra imaum & Chap. 6,15 & & Scythia & SCHITIA EX IMAV & $\begin{array}{l}\text { SCHITIA EXTRA } \\
\text { LAMVM }\end{array}$ \\
\hline SERICA REGIO & Seri ca regio & Chap. 6,16 & & $\begin{array}{l}\text { Xinjiang } \\
\text { (China) }\end{array}$ & $?$ & SERICA REGIO \\
\hline SINARVM REGIO & Sina rum regio & Chap. 7,3 & & China & SINA RVM RE ${ }^{\circ}$ & SINARVM REGIO \\
\hline SEMANTI & $\mathrm{XXX}$ & $7,3,4$ & & in China & & \\
\hline SEVLA & $\mathrm{XXX}$ & & $\mathrm{x}$ & $\begin{array}{l}\text { Marco Polo, Angaman } \\
\text { Insula (Behaim) }\end{array}$ & & $\mathrm{XXX}$ \\
\hline SINVS MAG & $\sin 9 \operatorname{mag}$ & Chap. 7,2-3 & & Bay of Bengal & & $\mathrm{XXX}$ \\
\hline SORAE & $\mathrm{XXX}$ & $\mathrm{x}$ & & Sora Arati Regia & & $\mathrm{XXX}$ \\
\hline SPIORAE & $\mathrm{XXX}$ & $\mathrm{x}$ & & $\begin{array}{l}\text { Murfoli Region } \\
\text { (Behaim) }\end{array}$ & & $\mathrm{XXX}$ \\
\hline TAPR OB ANA & tapro bana & Chap. 7,4 & & Sri Lanka & TA PRO BAN & TAPROBANA \\
\hline TROPICVS CANCRI & Tropicvs cancri & $\mathrm{x}$ & & Northern Polar Circle & TROPIC CANCRI & $\begin{array}{l}\text { TROPICVS } \\
\text { CANCRI }\end{array}$ \\
\hline TROPICVS CAPRICO RNI & Tro pic9 capricor ni & & & Southern Polar Circle & $\begin{array}{l}\text { CIRCVLVS } \\
\text { CAPRICORNI }\end{array}$ & XXX \\
\hline TIG & $\begin{array}{l}\text { RIVER IS NOT DEPICTED } \\
\text { XXX }\end{array}$ & $\mathrm{x}$ & & Tigris & & $\mathrm{XXX}$ \\
\hline ZIPA GRI & zipa gri & & $\mathrm{x}$ & Japan & ZIPAG RI & ZIPANCRI \\
\hline \multirow{4}{*}{ SYMBOL OF JERUSALEM } & & & & & MNCA (=island) & $\mathrm{XXX}$ \\
\hline & & & & & ARBET (=ISLAND) & $\mathrm{XXX}$ \\
\hline & $\mathrm{XXX}$ & $\mathrm{x}$ & & & $\mathrm{XXX}$ & $\mathrm{XXX}$ \\
\hline & & & & & & $\begin{array}{c}\text { RARISSIM: HIC } \\
\text { SUNT } \\
\text { DRAGONES } \\
\text { ALBANIA; } \\
\text { BABVLONIA; } \\
\text { BACTRIANA; } \\
\text { CIRTENA; } \\
\text { IVDEA; VARP R; } \\
\text { INDVS; PARTHIA; } \\
\text { GENGEM } \\
\text { FLVVIVM; SIRIA; } \\
\text { SIMARVM SIT } \\
\text { (VS); } \\
\text { TRALMAVM }\end{array}$ \\
\hline $\begin{array}{l}\text { B. AMERICA SUBTOTAL } 4 \\
=\mathbf{4} \% \\
\text { COD }\end{array}$ & $\begin{array}{l}\text { B. AMERICA: } \\
\text { SUBTOTAL } 2=4 \% \\
\text { ISLAND IS NOT } \\
\text { DEPICTED XXX }\end{array}$ & & $\mathrm{x}$ & RARISSIM & & $\mathrm{XXX}$ \\
\hline NOVA & $\mathbf{X X X}$ & & $\mathrm{x}$ & Terra Nova & & $\mathrm{XXX}$ \\
\hline $\begin{array}{l}\text { AMERICA NOVITER } \\
\text { REPERTA }\end{array}$ & America & & $\mathrm{x}$ & South America & $\begin{array}{l}\text { AMERICA NOVITER } \\
\text { REPERTA }\end{array}$ & $\mathrm{XXX}$ \\
\hline
\end{tabular}




\begin{tabular}{|c|c|c|c|c|c|c|}
\hline \multicolumn{7}{|l|}{ Continued } \\
\hline \multirow[t]{6}{*}{ OCCEANVS OCCIDENTAL } & Occenus Occidental & & $\mathrm{x}$ & $\begin{array}{l}\text { EAST.PACIFIC } \\
\text { OCEAN }\end{array}$ & & $\mathrm{XXX}$ \\
\hline & & & & & TERRA DE BR AZIL & $\begin{array}{l}\text { TERRA DE } \\
\text { BRAZIL }\end{array}$ \\
\hline & & & & & MONDVS NOVVS & MVNDVS NOVVS \\
\hline & & & & & $\begin{array}{l}\text { TERRA SAN CTAE } \\
\text { CR VCIS }\end{array}$ & $\begin{array}{c}\text { TERRA SANCTAE } \\
\text { CRVSIS }\end{array}$ \\
\hline & & & & & ISABELLA & ISABEL \\
\hline & & & & & SPAN & SPAGNOLLA \\
\hline $\begin{array}{c}\text { C. AFRICA: } \\
(\text { TOTAL 27) }=29 \%\end{array}$ & $\begin{array}{c}\text { C. AFRICA: SUBTOTAL } 10 \\
=18 \%\end{array}$ & & & & & \\
\hline AFFRICA SVPERIOR & AFFRICA & & $\mathrm{x}$ & $\begin{array}{l}\text { RARISSIM: } \\
\text { SVPERIOR }\end{array}$ & AFFRICA & AFERICA \\
\hline AFRICA MINOR & Affrica minor & Chap. 4,3 & & $\begin{array}{l}\text { Only called } \\
\text { "Africa" province } \\
\text { in Ptol. }\end{array}$ & & $\mathrm{XXX}$ \\
\hline AEGIPTVS & $\mathrm{XXX}$ & Chap. 4,5 & & Egypt & AEGIPTA & EGYPVTS (check) \\
\hline AZANIA & $\mathrm{XXX}$ & $4,7,28$ & & Somalia & & $\mathrm{XXX}$ \\
\hline CIRENE & $\mathrm{XXX}$ & $4,4,11$ & & $\begin{array}{c}\text { Cyrenaica } \\
\text { (Eastern Lybia) }\end{array}$ & & $\mathrm{XXX}$ \\
\hline CO LOBI & $\mathrm{XXX}$ & $4,7,28$ & & $\begin{array}{l}\text { Kolober } \\
\text { (Ethiopia) }\end{array}$ & & $\mathrm{XXX}$ \\
\hline CINNA MIFERA & $\mathrm{XXX}$ & $4,7,34$ & & $\begin{array}{l}\text { Cinnamon } \\
\text { Region } \\
\text { (NE Somalia) }\end{array}$ & & $\mathrm{XXX}$ \\
\hline ETHIOPIA SUB EGITO & Ethiopia sub egipto & Chap. 4,7 & & East Africa & & $\mathrm{XXX}$ \\
\hline ETHIOPIA INTERIOR & ethiopia interior & Chap. 4,8 & & Central Africa & & $\mathrm{XXX}$ \\
\hline G & $\begin{array}{l}\text { ISLAND IS NOT DEPICTED } \\
\text { XXX }\end{array}$ & & $\mathrm{x}$ & $\begin{array}{l}\text { Gamaa } \\
\text { (Cantino) }\end{array}$ & & $\mathrm{XXX}$ \\
\hline GETVLIA, & $\mathrm{XXX}$ & $\begin{array}{c}4,2,13 ; 4,3,15 \\
4,6,15\end{array}$ & & Central Sahara & & $\mathrm{XXX}$ \\
\hline GARADVRI & $\mathrm{XXX}$ & & & RARISSIM & & $\mathrm{XXX}$ \\
\hline LIBIA INFERIOR & libia inferio $r$ & Chap. 4,6 & & Libia Interior & LIBIA INTERIOR & LIBIA INTEROIR \\
\hline LIBIA & libia & $\mathrm{x}$ & & Africa: Continent & LIBIA & LIBIA DESERTA \\
\hline M & $\begin{array}{l}\text { ISLAND IS NOT DEPICTED } \\
\text { XXX }\end{array}$ & & $\mathrm{x}$ & $\begin{array}{l}\text { Marfia } \\
\text { (Behaim) }\end{array}$ & & $\mathrm{XXX}$ \\
\hline MADAGAS & madigas. & & $\mathrm{x}$ & $\begin{array}{l}\text { Marco Polo, } \\
\text { Madagascar } \\
\text { (Cantino) }\end{array}$ & MA DA GASCAR & MADAGASCAR \\
\hline MAVRITANIA & mauritania & Chap. 4,1-2 & & Mauretania & MAURITA & $\begin{array}{c}\text { MACVSI (Ma- } \\
\text { chusier in Maurita- } \\
\text { nia) }\end{array}$ \\
\hline MACIAE & XXX & & & $\begin{array}{l}\text { Terra d'Malaget? } \\
\text { (Behaim) }\end{array}$ & & XXX \\
\hline MO SILI & $\mathrm{XXX}$ & $4,7,27$ & & $\begin{array}{l}\text { Cape Gulf of } \\
\text { Aden } \\
\text { (Mosyl) }\end{array}$ & & $\mathrm{XXX}$ \\
\hline NIL & $\begin{array}{l}\text { RIVER IS NOT DEPICTED } \\
\text { XXX }\end{array}$ & $\mathrm{x}$ & & Nile River & PALVDES NILLVS & PALVDES NILI \\
\hline NVBAE & $\mathrm{xxX}$ & $4,6,16$ & & $\begin{array}{l}\text { Tribe from Nubia } \\
\text { (Niger) }\end{array}$ & & $\mathrm{XXX}$ \\
\hline PEROR SI & $\mathrm{XXX}$ & $4,6,16$ & & $\begin{array}{l}\text { Tribe of Perorsi } \\
\text { (Nigeria) }\end{array}$ & & $\mathrm{XXX}$ \\
\hline RHEPSIL & $\mathrm{XXX}$ & $4,7,12$ \&. $4,8,3$ & & Rhapta, Rhapsier & & $\mathrm{XXX}$ \\
\hline $\begin{array}{l}\text { REGIO MAG NAIN QVA } \\
\text { ELEPHANTI ALBI }\end{array}$ & XXX & $4,8,4$ & & $\begin{array}{l}\text { Southern Africa, } \\
\text { White Elephant }\end{array}$ & & $\mathrm{XXX}$ \\
\hline
\end{tabular}




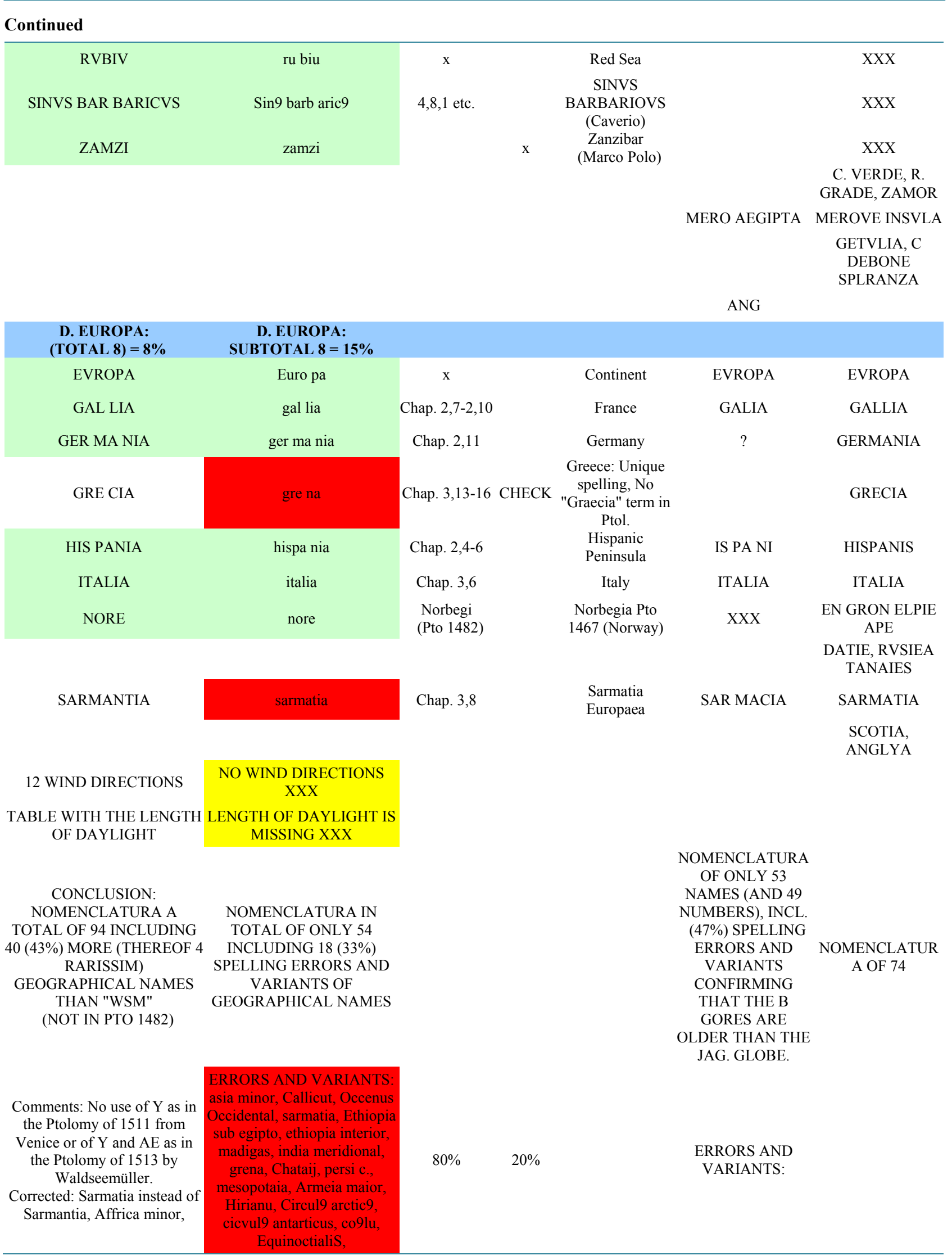


perience that incorrect spellings tend to accumulate the younger the manuscript, and the evidence that the globular map woodcuts accumulated numerous incorrect spellings and variants, allows for the preliminary conclusion that the woodcut is an abridged replica of the copper engraving, and not the reverse. To substantiate this statement I refer to the results as shown in Table 4.

The geographical distribution of the nomenclature on this globular map is: 55 (58\%) for/on Asia, 4 (4\%) for/on the New World/ America, 28 (30\%) for/on Africa and 8 (8\%) for/on Europe.

In comparison, the woodcut globular map of the UB Munich has in total 54 geographical place names include geographical definitions which are $42 \%$ less in total amount than this copper engraved globular map.

Their comparative distribution on the world map is: 34 (62\%) for/on Asia, 2 (4\%) for/on America, 11 (20\%) for/on Africa and 8 (15\%) for/on Europe.

Not only are $56 \%$ of the nomenclature replicated (the remaining $44 \%$ being omitted), but also their positioning do not vary. This can be easily compared taking the 8 identical names and locations on the European continent (see Compilation File 1).

The most crucial evidence are the numerous misspellings, distortions, discrepancies and variants incl. the different use of capital letters extant ONLY on the woodcut globular maps and not on this copper engraved globular map.

The result of the "spot the difference" test, which is shown at the bottom of Table 4, and which is the most significant Table of this paper, is this list of names which include all errata, variants and misspellings on the woodcut globular maps:

"asia minor; Callicut; Occenus Occidental; sarmatia; Ethiopia sub egipto; ethiopia interior; madigas; india meridional; grena; Chataij; persi c.; mesopotaia; Armeia maior; Hirianu; Circul9 arctic9; cicvul9 antarcticus; co9lu; Equinoctialis.”

To put it distinctly: if this globular map were to be a reprint from the woodcut version, as has been repeated over and over, why then are none of the above so numerous misspellings from the woodcut version reproduced on this globular map?

The above evidence refutes a theory based on assumptions and speculations which held for the past 133 years.

To further underline the above statement that the woodcut globular maps are copies of the 1 sample of this globular map, I investigate the content of the unique sample of this globular map compared to the ones of the UB Munich. All 5 aspects mentioned where I tested the "spot the difference" technique are repeated. Extra features are:

-The latitude notation is highly detailed and even includes the length of the hours of sun during a day, is in the interval line 280-290 degrees East between ZIPAGRI and AMERICA.

-The globe segments are uniquely, didactically numbered (reversed) in the double engraved line for the equator.

-The city of Jerusalem is identified with an orb with a cross on it, which is a crucial mark for a catholic connotation. It has been confirmed that Germanus was a Benedictine Monk ${ }^{93}$.

The facts that the size and shape and the location of Madagascar is identical with Madagascar on the UB Munich, the location of Calicut is to the West of Taprobana, the location of which was known prior to the arrival of Vasco da Gama in Calicut in $1488^{94}$, and Japan is spelled Zipagri, with the letter "N" missing as in the UB Munich, is the further confirmation that the woodcut globular map of UB Munich and subsequently the later 4 known ones, are made simple reprints of this copper engraved globular map that is the prototype.

\subsection{A Phrase Referring to "Other Printed Globes" in the CI Edited by Boulengier}

The woodcut globular maps do not mention the duration of the day and night, a "missing" detail which will prove to be rather meaningful in the course of this research.

In the CI, thought to be printed in Lyon in c. $1510^{95}$, L. Boulengier prints this didactic phrase "Ad Lectorem:

\footnotetext{
${ }^{93}$ I thank Dr. P. Meurer for his mail dated November 23rd 2013 and the reference to footnote ix from his Article in the Neue Deutsche Biographie O.2.1. Nicolaus Germanus.

${ }^{94}$ On the Frau Mauro map c. 1450, kept in Venice, Calicut is called Cholocut. I thank Dir. Dott. P. Falchetti for his personal mail 27.12.2013. I also thank Dr. F. Mittenhuber for his comments in his mail of 4.1.2014. As CALICUT is only known since the $13^{\text {th }}$ century, it is not depicted on Ptolemaic maps such as the Ulmer and others.

${ }^{95}$ Apparently, the prime source of this erroneous date was Brunet (1860-78) and his Manuel du librairie et de l'amateur de livres, 6 vols et supplément (Paris, 1860-78), vol. I., p. 318. Although he used the conditional "must have been printed in 1510", this was copied by all as "was printed in 1510" https://archive.org/stream/cosmographiaeint00wald_1\#page/n23/mode/2up
} 
Habies candide lector tabellam preinsculptam tibi latitudinem graduum regionum: orarum quantitatem existentem quodlibet in paralello ostendentem, in globo vero diei quantitatem et noctis...sic comprendere potes omni de regione tam per globum quam per sexagenarium" "96 (Figure 6).

The Sexagenarium which is a extraordinary medical instrument is mentioned a second time at the bottom of the second but last page.

The English translation:

"Dear reader, you have before you a small engraved plate on which are inscribed the degree of latitudes of the countries... and on the globe you see the duration of the day and night. Thereby you will be able to ascertain the position of every country by the globe as well as by the sexennium" (Stevenson, 1921: footnote 178). Page "C". For one reason or another, I could not locate any such world map printed in any of the CI's at all. A possible reason was perhaps secrecy.

The length of the day and night were not only imperative to define the degree of latitude, but were an essential tool, even prerequisite for astrologers, and medical astrologers in particular.

No other than this globular copper engraved map has the hours of the day inscribed on them.

The author of this text may conceivably be the Medical Doctor of J. Robertet named Capella or more likely the Medical Professor Symphorien Champier ${ }^{97}$.

Henry Harisse mentions the above paragraph in his personal handwriting in the preface of the CI Lyon version, with his personal ex libris "Nov Eborac". He purchased this edition in September 1909 in a store of B. Hernandez in Toledo, Spain.

He refers to "ten extremely curious lines" without commenting them, and specifies that the Paris Arsenal ver$\operatorname{sion}^{98}$ does not contain this remarkable page" AD LECTOREM" with the " $\mathrm{C}$ ",99. I detected that the Library of the City of Lyon owns one complete volume (https://app.box.com/s/ldsrm6bqu994e1lw33s4) and a watermark could be identified. It is Briquet 8015, Angoulême: date $1505^{100}$ (Figure 7).

The similarity was confirmed by the director of the Printing Museum from Lyon $^{101}$. Harisse fails to mention that the editor refers on the second page to a globe which he, Boulengier, has identified in printed form. It was possible to locate and identify in total 10 copies in public libraries: Paris BN (1), Paris Bibl. Arsenal (2) Lyon (1), London (2), NY (2), Providence (1) and Indiana (1).

The research of these copies, (see Appendix 2: Comparative Analysis and focused collation of the extant Cosmographiae Introductio printed in Lyon), led to the conclusion that there are at least 2 different editions of the CI printed in Lyon.

These are characterised by a horizontal versus a vertical printing of the "Ad Lectorem" page 2 different kinds of paper and 2 different watermarks, but only one could be identified. The second watermark constitutes also a

\footnotetext{
${ }^{96}$ Of this unique instrument, which originates from the Spanish Peninsula (Valencia), I was able to identify, with the help of the President and Expert Jan de Graeve (mail dated November $2^{\text {nd }} 2014$ ), one single instrument in a public institution: it is the St. John's college Sinecal and Quadrant and Sexagenarium c. 1500 (Inv. Nr. 16856) kept at the Museum of Science in Oxford. I presume that the Medical Doctor and Historian active in Lyon in the early XVIth Century, Symphorien Champier may have known about this instrument: He was c. 1506 the publisher of a bibliographical history of medicine in which he still esteemed Avicenna as the noblest medical doctor. Further research will be needed to make this conjecture. I refer to Siraici (1987), Avicenna in Renaissance Italy, The Canon and Medical Teaching in Italian Universities after 1500, Princeton Legacy University, Princeton, 1987, p. 72.

${ }^{98}$ I controlled this statement and the Arsenal Library confirmed by mail dated 18.12.2014 that the copy with the signature 4-H-33 is the one that Harisse looked at. At the NYPL, the signature for the 2 different copies, one which has the "AD LECTOREM" vertically instead of horizontally is: *KB1517. http://catalog.nypl.org/record=b14353394 S1.The copy at the Bibliothèque Mazarin has the Sig. Quarto 15680-3 (res). The British Library has one copy 6568.e.26 which also lacks the "AD LECTOREM" page, and one incomplete one. G 6536 (C.20.b.16). I thank P. Barber for his communication by mail dated Nov. $28^{\text {th }} 2014$. The University Library of Indiana has 1 copy: E125.V6 W15 1517VAULT. (Formerly Bernardo Mendel Collection) which has the identical watermark Briquet 8015 as the Lyon CI copy. More importantly, the Arsenal Library in Paris has 2 copies (both of which have the identical partial watermark of the 2 copies at the NYPL). In addition 4 H 32 surprisingly has the Ex Libris of Guillaume de Cambrais (1430-1505). The fact that the ex libris is still used shortly, such as 1507, after the decease of the owner of the library (example Nicolas Fouquet) is not unusual according to the Librarian Martine Lefèvre from the Arsenal. Mail dated 17.12.2014.

http://babel.hathitrust.org/cgi/pt?num=150\&u=1\&seq=99\&view=1up\&size=100\&id=hvd.32044058255795\#view=1up;seq=159, son of the very rich Geoffrette Coeur and Jean de Cambrais, officer and bread baker of King Charles VII th). Cachet Seminaire Saint Sulpice. Ad Lectorem printed vertically) and $4 \mathrm{H}$ 33. (The "Ad Lectorem" page is missing) Mails from Mm. M. Lefevre dated: 16th and 18th 12.2014. For a summary, which does not pertain to be complete, I refer to Appendix 2 according to M. Lefèvre, the ex Libris could also have belonged to a relative with the same name, somewhat later.

${ }^{99}$ JCB Digital Version Online www.josiah.brown.edu Cosmographiae Introductio Signature R J 517.W168c.

${ }^{100}$ Mail by Dir. Pierre-Antoine Lebel dated from December $2^{\text {nd }} 2014$.

http://www.ksbm.oeaw.ac.at/_scripts/php/loadRepWmarkImgPDF.php?rep=BR\&refnr=8015\&lang=fr

${ }^{101}$ I thank Dir. Pierre Antoine Lebel for his kind assistance. The Catalogue Number in Lyon is Rés 357275.
} 


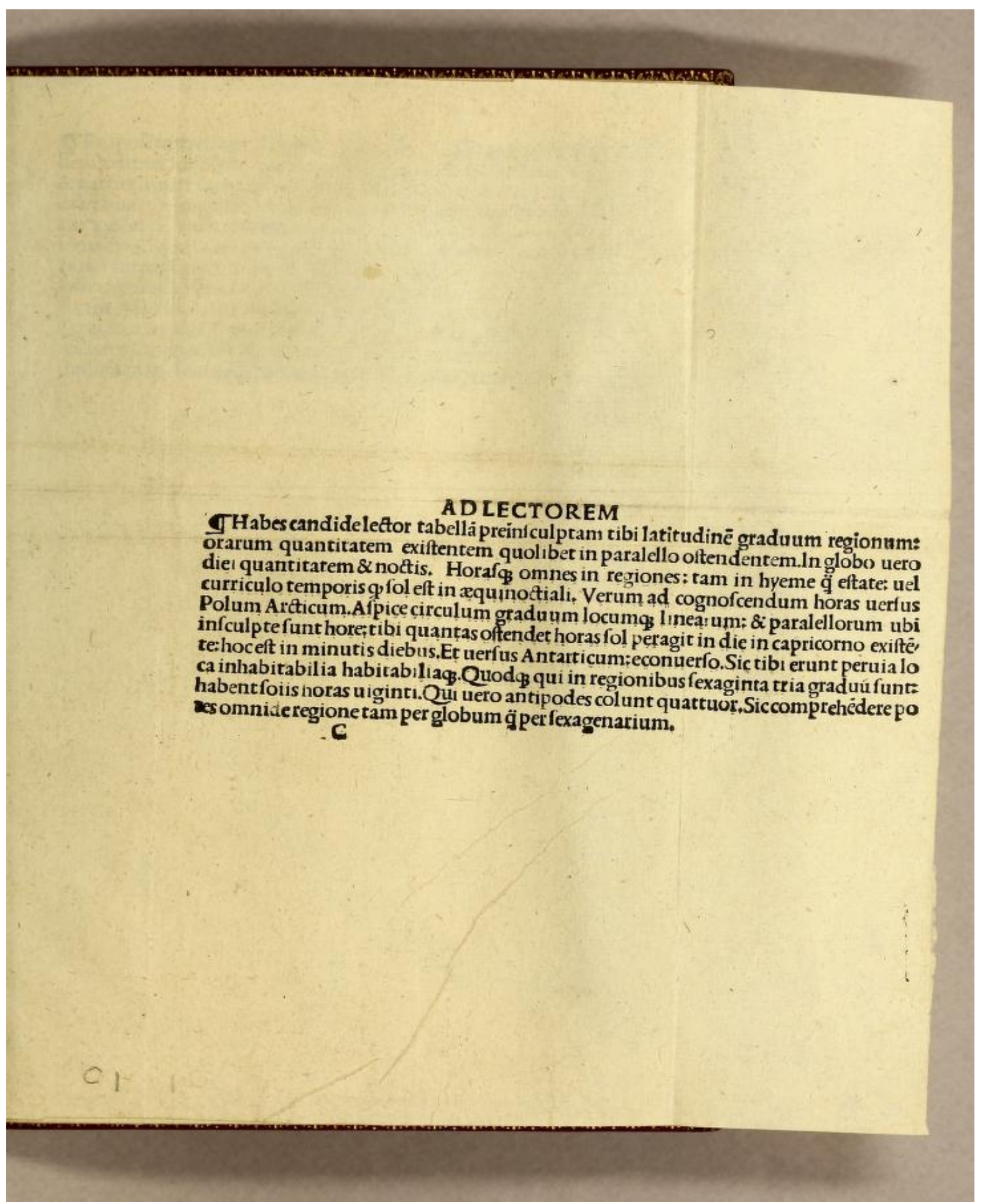

Figure 6. Ad lectorem (Source: JC Brown library volume of the CI of Lyon).

letter B, but could only partially be exposed. The version 4-H-32 at the Arsenal Library has according to the Librarian Monique Pelletier the Ex Libris of the Bishop of Bourges, Guillaume de Cambrais, who died in 1505! This is possibly a decisive piece of direct evidence that the CI of Lyon was not printed as late as 1517. One theory is that it was not uncommon that an Ex Libris was continued some time after the deceasing of the owner of 


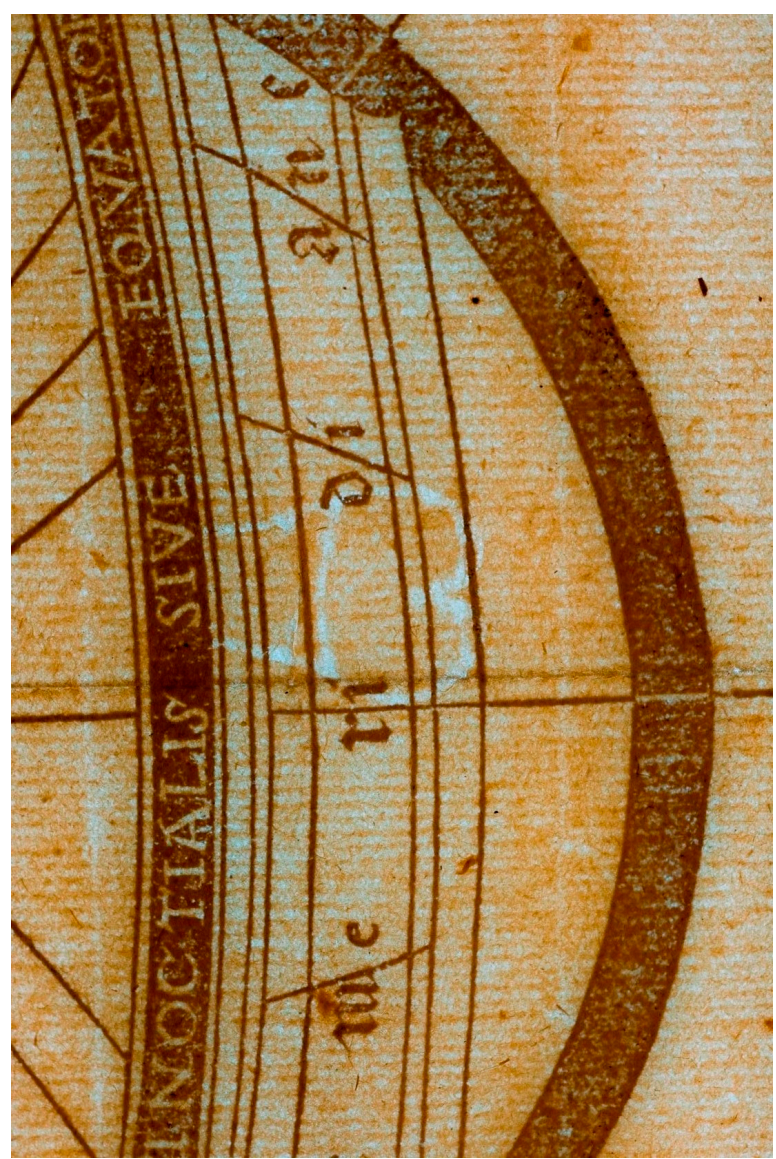

Figure 7. Watermark CI of Lyon.

an important library, but it is impossible that this Ex Libris would have been continued until 1517 or asmuch as 12 years after his death.

Worth knowing, it was not possible to identify any edition of the Lyon printed version of the CI in any, Austrian, Belgian, Italian or in a German Library ${ }^{102}$. I estimate that in public libraries worldwide there are maybe up to c. 70 volumes of the four original Waldseemüller editions printed in 1507 in St. Dié ${ }^{103}$. A number of libraries have all four original Waldseemüller editions of 1507 such as the NYPL.

On the codiform projected map of Contarini/Rosselli of 1506, a copper engraving, the only extant copy is at the British Library; CALICUT is spelled and located to the West of Taprobana as on the c. 1502 Portolan map named King Hamy (Huntington Library) ${ }^{104}$. The above arguments provide the final evidence that the attribution of the small globular maps to Waldseemüller is erroneous. At the same time, one questions if Waldseemüller knew about the existence of the small globular map.

\section{Any Proof of a Relationship between Waldseemüller and This Globular Map?}

Every cartographer knows that it takes great financial resources, know-how and geographical skill to prepare for a detailed woodcut print, even if it is small. Miniaturisation requires expertise.

Harisse dated this globular map c. 1510, because he had read that it was the year that Jean de la Place started his printing business. This argument by Harisse lacks any kind of substantiation as he erroneously puts his dating on the mere matter of the loose insertion in a CI printed by Jean de la Place. His date would be one year after the printing of the phrase "America Noviter Reperta" in the Globus Mundi, but in this case it is the reverse e.g. this globular map encouraged the printing of the Globus Mundi, mainly because the level of "precision" of this

\footnotetext{
${ }^{102}$ This was confirmed by Dr. Hogrefe, Wolfenbüttel Library, by Mail 8.12.2014

${ }^{103}$ This rough estimate is based on the online research of the KVK and the World cat data base. Accessed: 21.12.2014.

${ }^{104}$ For the King Hamy Map I refer to: http://upload.wikimedia.org/wikipedia/commons/b/be/King-Hamy map.jpg.
} 
globular map is much higher than the woodcut map of the world in the Globus Mundi.

Another variant which is conceivable is that both were made totally independent from each other.

The large world map of Waldseemüller does not have a deep gulf and the extension of the coast southward goes as far as the $18^{\text {th }}$ latitude North.

Only two archetypes are known where the North-western continental land ends at approximately the same parallel. It is the Cantino and this globular world map.

No other globular map in the world has numbered gores which Harisse failed to notice as he did not have the original to look at. No woodcut or other globular map in the world has the sentence "America Noviter Reperta". No other globular maps have the detailed numbered latitude notation on the interval line between 280-290 degrees east.

Is this location of the interval line, which is so characteristic for this globular map and which is not shown in the small insert map, as part of the big Waldseemüller world map, there is proof that this globular map was developed independently from Waldseemüller. And there is supplementary proof in how the complete hemisphere of the New World is depicted, in addition to the 1504 Caverio Portulan Map on which this interval so characteristically ends (Stevenson, 1908: p. 82)?

Hessler makes notice of the issue that "it is probable that Waldseemüller had geographic information that is no longer extant or has yet to be discovered for his 1507 portrayal of the new world" (Hessler, 2006: pp. 101113). I believe that Waldseemüller did not have access to this copper engraved globular map. A crucial question for many readers maybe what the reasons were that for the last 181 years or so nobody noticed this "inaccuracy"? That is what I look at in the next paragraph.

\section{What Were the Most Decisive Arguments Which Led to the XIX Century Erroneous Attribution and Dating Until Now?}

Some of these flaws were the result of c. 181 years of "Blinded Research" (beginning by Alexander von Humboldt (1769-1859) in 1831) or some analysis based on maps at a time that it was thought they existed, but were only exposed at the beginning of the 20th century. This was the case of the large hidden world map by Waldseemüller found in 1901 in the "Wolfegg Codex" (Maruska, 2008: p. 155) owned by J. Schöner in 1901 and the woodcut globular map disclosed in 2012 in Munich.

Here I summarize and show a chain list of flaws and former reasons and explanations from 1-25, some of which resulting from this $19^{\text {th }}$ and $20^{\text {th }}$ blinded century research, and give explanatory comments, for what reason they may have been accumulating.

\subsection{The Volume in Which This Globular Map Was Detected}

The "Corpus Delicti" so to speak, was the Lyon version of the CI edited by Louis Boulengier. This was reason sufficient to attribute this globular map to this person, although he was only the Commercial Publisher and Decorator. This globular map and the other 2 copper engravings could have been inserted in any other kind of volume.

So, c. 1514 and 1517-1518 were used as a date and the attribution to "this completely unknown French cartographer Boulengier" (Marcel, 1889: p. 166), who worked and lived in Albi and subsequently in Lyon was made. What surely added to the confusion was the evidence that only one exemplar of this globular map was found and it was inserted in a so rapidly defined "counterfeit" reprint (Marcel, 1889: p. 171) of the Waldseemüller $\mathrm{CI}^{105}$.

The Lyon version of the CI includes the naming of America, one woodcut diagram of a "globe" and one woodcut from a sphere. It is not at all a mere reprint or even a plagiate reprint. Copyright was only "invented" later.

The above is an adapted and enlarged version in which astrological, geographical ("latitudinem, longitudinem") and contemporary meaningful medical aspects ${ }^{106}$ ("parti medicine, medicamenta") were somewhat prophylactically added. H. Harisse stated in his handwriting that these additional aspects are difficult to capture.

\footnotetext{
${ }^{105}$ Not to be confounded with J.C. Boulengier, a Jesuit Priest, depicted with a Globe, Clermont College, Paris, 1588, BNF, Latin 10822 , fol. $261 \mathrm{v}$.

${ }^{106}$ The edition of the CI which is part of the J.C. Brown University Library has faded hand written side reference at the bottom of the Recto page F. This phrase was deciphered by Dr. Armin Schlechter: "dende a j Mirandu Comperies". It may mean "(you will be) astonished to find that". It may refer to "Miranda praestare comperies lac asinium", which also appears in the "De Febre Maligna" (bad fever) as part of Thomas Longas "Enchiridion novae \& antiquae medicinae dogmaticae..." by Tomás Longas (c. 1620-1690) who is known to have reproduced the clinical history of fever, including Galen, and one of the first to have administered intravenous injections.

http://thebiography.us/en/longas-tomas I thank Med. Doctor Maurits Biesbrouck for his explanatory mail dated 19.12.2014.
} 
The difference in the typography and typesetting between the first part of the text regarding the cosmography and the latter part that copies the letters of Amerigo Vespucci is another proof that this edition is not just a servatile replica.

A further quotation in the CI of Lyon is made to the Persian polymath and medical doctor, author of the Canon of Medicine (Arabian), Avicenna (980-1037) and the Greek Physician and Father of the Western medicine, Hippocrates of Cos (BC c. 460-c. 370) (Avezac, 1867: p. 118). In Waldseemüller's CI there is no reference quotation or allusion to Medicine in general and to Avicenna or to Hippocrates in specific ${ }^{107}$.

\subsection{Not Taking into Account the Reality of the Competitive Printing Business}

Rather essential, I found Waldseemüller complaining about an unauthorised edition of his work. He noticed this "plagiate" of his work while travelling in France on his way to Germany to participate in Carnival ${ }^{108}$.

It is in the first quarter of 1508 , when Waldseemüller complains about others who falsely attributed his work to themselves: "meo potissimum ductu et labore licet plerique alii falso sibi passim ascribant Cosmographiam vl'em tam salidam quam planam non sine Gloria et laude per orbem disseminatam nuper composuimus, depinximus et impressimus..."109.

He writes a letter to warn his working colleague and poet Mathias Ringmann (Philesius). This letter is printed, and until now, was interpreted that he was complaining about others from his team in St. Dié.

This historical argumentation no longer holds because Waldseemüller himself writes this to his colleague, member of the "Gymnasium Vosagense" while travelling and even more essential, being the only one who has his name printed explicitly as "MARTINUS ILACOMILUS" on the second page of the first and fourth edition "GYMNASIUM VOSAGENSE", on the back page of remaining 3 editions, all prior to 1508 (Wieser, 1907: pp. 8-24).

No extant plagiate edition by any of his other colleagues like Walter Ludd (secretary of the duke René II), or the translator and elegant poet Johann Basinus Sendacurius is known to exist. Ipso Facto, Waldseemüller refers to a copy by a third party, i.e. the one printed in Lyon prior to the End of Carnival 1508 !

Only a limited number of the adapted version of the CI have survived the ages in libraries but a French Edition of the large Waldseemüller World Map which possibly accompanied the CI of Lyon still needs to be ascertained. In the 1513 version of the Margarita Philosophica Nova the aforementioned Latin paragraph is shortened and only "Cosmographiam" is used (Laubenberger, 1959: p. 169). This is a mere indicator Waldseemüller only referred to his Cosmographiae Introductio and not to this large map.

The letter of Waldseemüller is a crucial contemporary piece of evidence and precedes due to its undisputed authorship secondary sources from third parties like Trithemus to which I come back later to this.

The letter is printed by Johannes Grüninger (1455-1532) in the first "new" edition of the unauthorised ${ }^{110}$ Margarita Philosophica Nova in Strasbourg dated March 31 1508 (Avezac, 1867: p. 107). This is approximately only one year after the first of 5 different CI editions were published in 1507 with Ringmann in St. Dié.

In other words Boulengier had a time span of 10 months to print, including proof reading, for his adapted Lyon version of the CI between April $25^{\text {th }} 1507$ and Cinerum, in English Ash Wednesday, which in the year 1508 fell on March $8^{\text {th }}$, while Easter was on April the $23^{\text {rd }} 1508$.

It is known that the rewriting and partial reproduction of printed material in this case a quarto sized (c. $24 \mathrm{~cm}$ $\mathrm{x} 13.8 \mathrm{~cm}$ ) booklet, with little artwork, only took a few months. The more printing presses a print shop had, the faster the production for the market could be accomplished ${ }^{111}$. As Jean de la Place who already started his business in 1498, and had survived the competitive printing business for numerous years, I may assume that he had several printing presses at his disposal.

It is relevant to acknowledge that the CI of Lyon is printed using the Roman characters, typical for that epoch. The typography is meticulous and proves evidence of spotless work and conscientious typographic setting.

As researched by Alexander von Humboldt (1769-1859), this letter from Waldseemüller explains why Wald-

\footnotetext{
${ }^{107}$ One CI Lyon version (quarto 15680-3) is kept at the Library Mazarine in Paris, but is incomplete. The NYPL has one copy in which the 3 loose copper engravings were found (* KB 1517) and the JC Brown UL in Providence Rhode Island has another copy which can be viewed online.

${ }^{108}$ I refer to the French translation on:https://archive.org/stream/martinhylacomyl00dgoog\#page/n120/mode/2up

${ }^{109}$ I thank the Vesalius Expert Dr. Maurits Biesbrouck for his transcription and mail dated 28.10.2014. http://bildsuche.digitale-sammlungen.de/index.html? $\mathrm{c}=$ viewer\&bandnummer $=\mathrm{bsb} 00007953 \&$ pimage $=305 \& \mathrm{v}=100 \&$ nav $=\& \mathrm{l}=\mathrm{en}$

${ }^{110}$ It is striking that Waldseemüller uses an unauthorised edition of the work of his teacher G. Reisch to print his letter complaining about others using his hard earned literary work. This is of interest, particularly as Boulengier his reputation as an editor is tarnished by accusations of plagiarism for "his" edition of the CI of Waldseemüller, specifically by Gallois.

${ }^{111}$ I thank Bibliophile Expert Jan de Graeve, President of the Belgian Bibliophile and Iconophile Society for his mail dated 24.11.2014
} 
seemüller in 1509 decides to assure that his name is put on subsequent printed material including the $1509 \mathrm{CI}$ Edition printed in Strasbourg and corrected by J. Adelphus ${ }^{12}$ and the subsequent Margarita Philosophica Nova 1513 (Humboldt, 1837: pp. 112-113) ${ }^{113}$.

It may also explain why Waldseemüller puts his name in very large letters on his large Map of Europe, dated $1511^{114}$ and even decides to turn the map upside down, making it more difficult to read (and reedit with the North at the bottom and the South on top).

The 1508 date of his complaint (Figure 8) puts a completely different light on the quick "reprint" of the French edition of the CI edited by Boulengier, and where he "left" the month less date of $1507^{115}$.

Why this is so relevant someone might ask?

As Boulengier acknowledges in his introduction of the CI to have identified "other globes printed earlier", this, as only the French edition(s) of the CI is (are) known to have been printed, offers evidence for the terminus post quem or earliest time of the event of Boulengier having detected this globular map prior to March 8th 1508 .

\subsection{Erroneous Interpretation of the Time of a Bishopric}

As if it was not enough to have the misguided attribution, also the date was conjectured on the unsound basis. The cathedral of Albi was a very symbolic French cathedral as it is the emblem of the victory against the Cathar Crusade.

The dedication of the Lyon version of the $\mathrm{CI}$ is to Jacques Robertet: "AD DOMINUM JACOBUM ROBERTETUM" who became canon of Albi and Vicar-General of his brother Charles (Heale, 2014). This dedi-

\section{Tltchitecture}

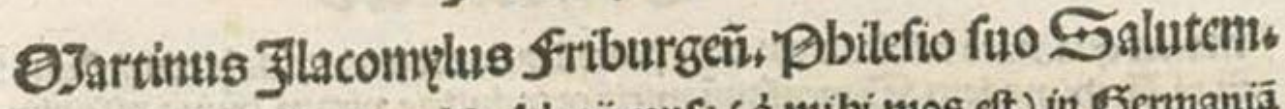

Lum bis oieb) IBacbanalibs folatü caufa ( (q mibi mos eft) in Eermania

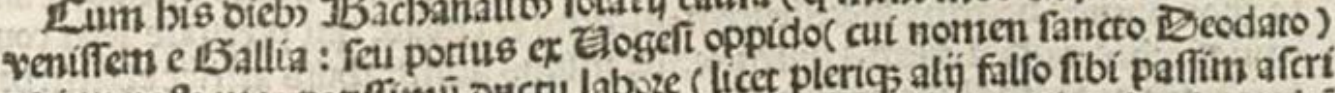

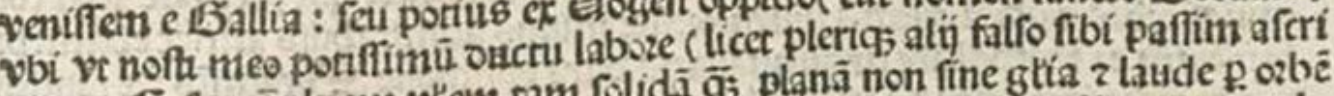

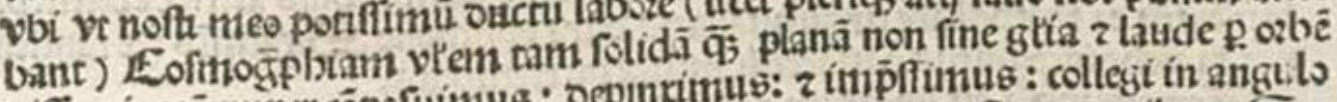

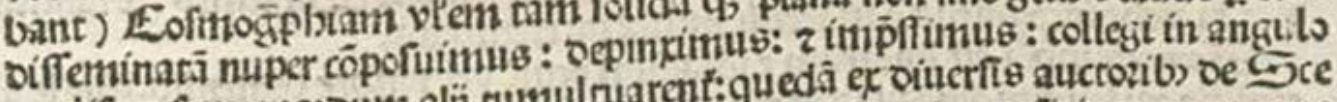

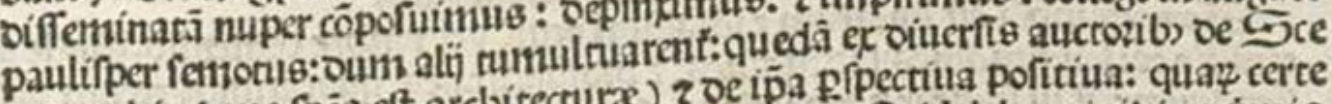
nograpbia (quę fpēs eft arclyitecturx) 2 oe īpa ef́pectiula pofitiua: quą certe

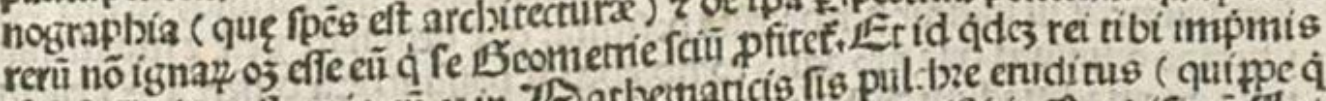

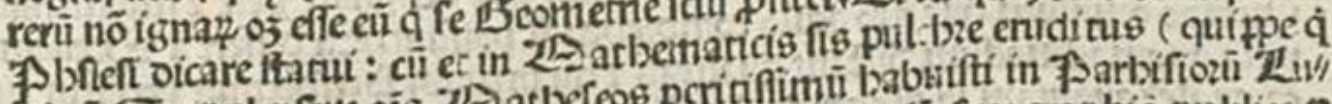

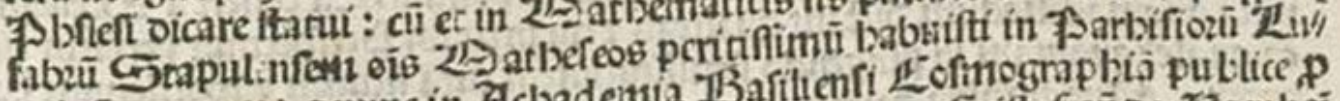

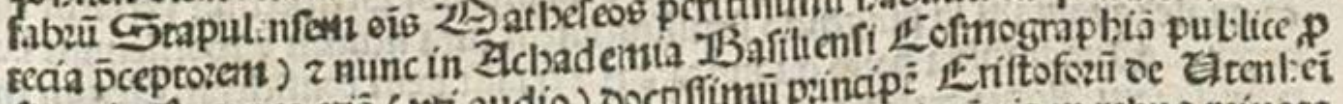

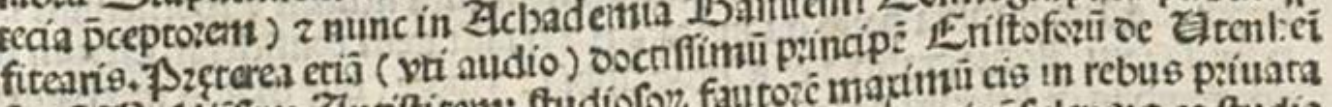
facrü IB zf́liçen Zintiftitem: ftudiofoy fautozé maximui cis in rebus paíuara lectione inftruxcris, ZGale mi Pbilefi: bęc äliacunq; boni cófuleng: $z$ en ftudia

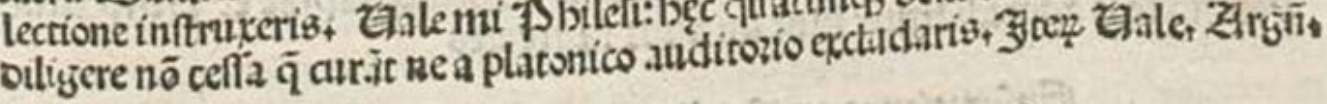

Figure 8. WSM Complaint of the French Copy of his work March 1508.

cation in the Lyon CI lacks the printed prerequisite i.e. the honorific title (Duclos, 1806: p. 19) ${ }^{116}$ of the catholic

\footnotetext{
${ }^{112}$ http://daten.digitale-sammlungen.de/ db/0001/bsb00011246/images/index.html?id=00011246\&fip=eayaxsqrseayayztseneayaeayaeayaeay asdas $x$ dsyd\&no $=36 \&$ seite $=7$

${ }^{113}$ Page 112 and page 113 refer to a Margarita Philosphica edition printed in 1513, but it is thanks to this research by the famous Humboldt and with the help of Dr. M. Lehmann (mail dated the $27^{\text {th }}$ of October 2014) it was possible to identify the 1508 printed version with Waldseemüller his earlier complaint.

${ }^{114}$ Of this magnificent cartographic treasure only one edition c. 1520 is extant. It is kept rather unobtrusively at a local museum in Innsbruck, Austria.

${ }^{115}$ In light of the many differences between the Lyon version and the St. Dié version the date of 1507 can be seen in another light, particularly as there is no date in the colophon. Nevertheless, José Alberto Amaro considers this date fictitious in his work on Amerigo Vespucci, Ensayo de bibliographía critica, Madrid, 1962. in Jean le pin op cit p. 116
} 
bishop or of the Archbishop which would be "EPISCOPUS or ARCHIEPISCOPUS"117.

It is relevant to draw attention to the fact that he was prothonotary, i.e. a prelate of the Holy Sea and that only this particular aspect is commemorated on the Epitaph of his tomb ${ }^{118}$. He was son of the French poet Jean Robertet of Montbrison and a former senator in the parliament of Grenoble (1466-1500).

This younger brother of the very influential Florimond I de Robertet is identical with Jean-Jacques who became provost of Grenoble; in 1500 he was already chancellor of the church of Lyon and prior of Saint-Rambert in Lyon, Canon of the Holy Chapel in Paris, Archdeacon of Bourges, Head of Orléans and Tournai, Canon of Paris and $\mathrm{Albi}^{119} \ldots$ and not to forget Prelate of the Vatican.

It is ascertained from a personally signed Ex Libris and his letter regarding a present including medical treaties from the Medical Doctor and Historian of Medicine Symphorien Champier (c. 1471-c. 1538) (20 $^{12}$ and J. Robertet his personal Medical Doctor "Maitre Michel de la Chapelle"121, that Jacques Robertet was in Lyon "Lugdunum...Anno 1508 in mense Martio". This means in March of 1508 (Pins, 2007: p. 116). Coincidentally Symphorien Champier, who approved the use of Astronomy, was befriended with Jacques Robertet. In addition, he was the first Physician i.e. Medical Doctor of the son of René II (Benefactor of Waldseemüller until December 1508), Duke Antoine de Lorraine (1489-1544) known as "The Good" as of c. 1509 (Pins, 2007: p. 83).

So, already, prior to c. 1510 Jacques Robertet was in Albi as Canon and Vicar-General. In 1512, while being Canon and Vicar-General, i.e. being a "High Person or Leader" to which the title "Presuli" as in the CI certainly applies, he participated twice at the royal court as a provincial delegate of the Languedoc to the Estates General. Albi is in the Languedoc (Pins, 2007: p. 116). To substantiate the above, I make reference to another author namely the Professor in Canon and Civil Law (Toulouse and Bourges) Jean Montaigne. In c. 1512 he uses a preparatory epistle in a booklet about "Si vendam tibi rem aliquam" addressed also to Jacques Robertet, prior of Saint Rambert in Lyon and Vice-General Vicar of Albi (Pins, 2007: p. 186).

In 1517, upon the request of the French King Francis I, he officially succeeded his brother, after being nominated in 1515 and became Bishop in Albi which he was until his death, sometime prior to May $26^{\text {th }} 1519$ (Pins, 2007: p. 116).

So even though without any substantiation because of the lacking of the bishopric title, the date for this globular map was erroneously based on a CI from Lyon when Jacques Robertet finally became Bishop of Albi.

\subsection{Limited Access to Information}

Another reason may have been that French historians and cartographers only had indirect access to a very small sample of woodcut globular maps. Avezac published his volume on Waldseemüller and his editions only in 1867 (Avezac, 1867) so he could not have known the 3 copper engraved plates which were only described in 1882 in NY.

\subsection{General Lack of Interest in Small Maps}

In 1998, the world map expert R. Shirley dryly puts it this way "the provenance, actual date of publication and details of the supposed author are still uncertain" (Shirley, 1998: p. 43).

\footnotetext{
${ }^{116}$ With the example of Episcopus in a procès-verbal at the time of King Louis I.

${ }^{117}$ I thank Dr. Armin Schlechter for his explanatory mail dated November 21, 2014.

${ }^{118}$ The epitaph on the tombstone, in the Chapel of Jacques Robertet which was built in 1510, contains the reference to the Holy Sea: "ISTA ROBERTETI CINERES TEGIT URNA JACOBI/QUEM VIGILEM EXPERTA ET ALBIA PONTIFICEM/CORPORIS AC ANIMI PRAECLARIS DOTIBUS AUCTUM/ANTE SUUM RAPUIT SORS TRICULENTA DIEM". In English: “This urn holds the ashes of Jacobus Robertet, the Albian papal defender and watchful man with great spiritual and talents which the gruesome destiny and fate wrested him to early for his age (days) from life. Source. $8^{\text {th }}$ Chapel Montbrison. Renon, Francois (Dom). Chronique de Notre-Dame d'Espérance de Montbrison, ou étude historique et archéologique sur cette église, depuis son origine (1212) jusqu'à nos jours, Roanne, Imprimerie de A. Farine, 1847, pp. 187-190.

${ }^{119}$ Hugues du Tems, Le Clergé de France, ou tableau historique et chronologique des archevêques, Tome premier, Paris, MDCCLXXIV, p. 147.

${ }^{120}$ I refer to P. Allut, Étude biographique et bibliographique sur Symphorien, Champier, Lyon, 1859. I thank Dr. Maurits Biesbrouck for his personal mail dated 22.11.2014.

${ }^{121}$ I refer to the Medical Doctor Michel de la Chapelle from Doornik/Tournai in Belgium who practised medicine in Lyon. He published a number of medical treaties including one on Avicenna in 1514.

https://books.google.at/books?id=inlmGzmRmycC\&pg=PA551\&lpg=PA551\&dq=maitre+\%22michel+de+capella\%22\&source=bl\&ots=U4 FZ4NsUfy\&sig=Nks2vNhXGdFASqIMvz6nf60A9A4\&hl=de\&sa=X\&ei=SxK6VNb-Hsv0UqjNgKgG\&ved=0CBMQ6AEwAA\#v=onepage $\& \mathrm{q}=\% 22 \mathrm{de} \% 20$ capella $\% 22 \& \mathrm{f}=$ false
} 


\subsection{A Strong Preconceived Perception}

The French cartographic expert L. Gallois puts in 1904 that there is no doubt that the Hauslab globular map was copied on a board which accompanied a later publication made in Lyon and this board even used a title directly inspired by the $1507 \mathrm{CI}$ (Gallois, 1904: p. 30). The evidence that there is no honorific title engraved on this globular map making reference to a bishop in Albi from that time is evidence of the contrary of the statement of L. Gallois. The common practise of the bishops and cardinals to be non-resident is neglected by Gallois.

\section{7. "Careless Science", Namedropping and Erroneous Conclusions from Avezac, Gallois, Marcel, Harisse etc. Not Having Payed Attention to the Original (Marcel, 1889: p. 164)}

In 1890 L. Gallois notices in his $\mathrm{PhD}$ thesis "the material disposition of the Globe of Lyon (= this globular map (CEGG) is identical to the globe by Waldseemüller: the same number of gores, the same division of degrees, the same drawing to the contours, the same special Waldseemüller type of manner of putting the African continent with regard to the Equator".

He continues in stating that "the author of the Lyon globe was an ignorant who embellished the sea at random with islands, particularly near the Eastern Coast of America as on the coast of Africa" (Gallois, 1904: p. 30). He identifies the 1513 World map by Waldseemüller printed in Strasbourg by J. Schott (Pastoureau, 1984: p. 375) as the source for the words on this globular map.

He concedes that the Globe of Lyon has a few (sic) more names than on the globe by Waldseemüller, and that the identical spelling of "Affrica" with $2 \mathrm{f}$ is an added proof of the "similarity" (Gallois, 1904: p. 51). In 1892 Gallois draws attention to the matter that the same spelling mistake like "SCHITIA INTA IMAUM" is reproduced from the pseudo Waldseemüller onto this globular map (Gallois, 1892: p. 107). He fails to notice the lapse "ZIPAGRI", which Waldseemüller spells "ZIPANGRI" on his large map and he fails to find the remaining numerous errata, misspellings and variants.

\subsection{Erroneous Interpretation of the Nomenclature and Timing}

The engraver uses Latin nomenclature and hydronomy omitting any type of Portuguese or Spanish or German toponyms, which is as shown in Table 4, exceptionally rich. The nomenclature on the 1513 woodcut world map by Waldseemüller is in Latin, but "Schytia intra imaum" is spelled correctly. Subsequent to a "second glance" of the 1513 World map with the nomenclature of this globular map there are so many differences to contradict Gallois' earlier statement. Africa is spelled with one F. "Affrica Svperior" and "Chataii" are wanting not on the map.

The quotation of "Albi" Elephant ${ }^{122}$ in Southern Africa, Caliqut and the Island of Cipangri are non existent. Gallois forgets that the several editions of the Ptolemy Atlas for example the one from 1482 were available to many cartographers and engravers.

The detailed Table 4 is the synopsis of the evidence that the inventor of this globular map selected Ptolemaic sources for c. $80 \%$ his nomenclature. The remaining c. $20 \%$ of his sources came from Marco Polo, de la Casa, Cantino and the layout for Behaim's globe whereby a few of them are unaccounted for such as "COD", "GARADVRI", "OCCENVS OCCIDENTAL" to the West of South America and "AFFRICA SVPERIOR".

The East coast of China reminds us of Behaim, and therefore of the Planisphere of H. Martellus (Beinecke Library at Yale University), with some exceptions including the huge island named Iava Maior and its parallel neighbour Candin. As to timing, 6 out of 7 CI (1507) were printed in the course of 2 years.

So why would the French, at the high time of the discovery of new territories "wait" 10 years until 1517 to have another version of the CI, printed, at a time when the growing amount of readership were demanding extra editions? Why would the power hungry French leave the spice market and the so expected gold to be explored by the Habsburgs (Spanish), or by the Medici's and by the Portuguese Kings etc...?

\subsection{Erroneous Belief. There Is No Evidence That the Large World Map by Waldseemüller Exhibited at the LoC Is a Geographical Source for This Globular Map!}

In other words, neither the world map by Waldseemüller nor its small insert map were an outline for this globu-

\footnotetext{
${ }^{122}$ According to O. Cabayé the name of Albi has no link with the Latin word "Alba" for the color white. Mail dated 2.1.2015.
} 
lar map. Both maps were made independently.

\subsection{The Word America}

As to the word America and as substantiated, it seems logical to state that the decorator of this globular map read the second April edition of the 1507 CI which forms the basis for the Lyon printed version. If this is the reason for the yet to prove but quite likely use of the phrase "America Noviter Reperta" on this globular map it is not certain. It would mean he had a layout of a composed and compiled World map by GERMANUS without the name of AMERICA, and subsequently, in late 1507, added the name.

\subsection{Some "Negligence" of Critical Sources with Regard to the French Military Presence in Italy}

Gallois adds an argument why Boulengier must have been a fantast. It is related to the way the Northern part of America is separated from the South American continent, and the way he depicts waves, capes and rivers on the West coast of the South American Continent. He ends by... "no way did Boulengier have access to any document to support this" (Gallois, 1892: p. 109).

\subsection{Indifferent Analysis of the Copper Material Used to Print the Globe Map}

Engravers in Italy were known for using the technique of copper engravings or intaglio. In France and Germany, copper engravings of maps were the big exception rather than the rule. The CI in which the gore map was found was not a copper engraving but a woodcut. I conclude that the CI and the inserted engravings must have different sources.

\subsection{Incomplete Research. Gallois Makes No Note Whatsoever of the Intended Size of the Globe for Which the Globular Map May Have Been Constructed}

Neither does he notice the printed numbering of the gores nor their artistic aspect. He fails to explain why the nomenclature differs between both examples. This is also the case for J. Fischer and Fr. Von Wieser, who were unsuccessful to see the importance of the differences between the hemispheric insert maps and the large world map and made use of the apparent differences of the Hauslab globular map with the large world map as a justification for the woodcut globular map to having being made by Waldseemüller.

\subsection{Preconceived "Opinions" and Wishful Thinking}

In the CI, by Matthias Ringmann who, as mentioned before, is credited for having invented the name "America", describing allegedly amongst others the world map of Waldseemüller, there is one phrase in Latin which is presented to argument that Waldseemüller produced a large map, a globe and therefore printed a small woodcut globular map.

This Latin phrase is "tam in solido quam in plano". The English translation of the Renaissance Latin is "both in solid and on a plane." This was interpreted erroneously. The word "solido" does not refer to a globe. The phrase refers to a spacious but zoom-like partial and sub-spherical flat or hemispheric projection. It is an attempt to represent a spherical surface on a sheet of paper or a plane (Snyder, 2003: p. 376).

In short, a flat sphere (planisphere) or plani-globe as the German Map Historian Dr. H. Wolff named it. In the case of the insert map, it is lacking 74 degrees of the North (omitting 24 degrees)-South (omitting 50 degrees), and shows 180 of specified longitude. The Austrian Jesuit and Cartographer Joseph Fischer (1858-1944) wrote in 1905 that "'solido quam plano' has been variously interpreted by scholars studying Waldseemüller's works"... ${ }^{123}$

The preparatory work for the polar stereographic depiction was created by Walter Lud ${ }^{124}$, in St. Dié prior to

\footnotetext{
${ }^{123} \mathrm{~J}$. Fischer came to the wrong conclusion! The difference in the indications of the degrees of latitude between the large map and the two insert maps, and the discovery of the Hauslab globe gores, which do differ from the large world map, is not a justification for the Waldseemüller to have made small globular maps nor a globe, or the insert maps being a globe. In: The cosmographical introduction of M. Waldseemüller (Hylacomylus) in facsimile.; followed by the four voyages of Am. Vespucci, with their translation into English, to which are added Waldseemüllers two world maps of 1507, with an introduction by Jos. Fischer and Fr. Von Wieser. Ed by Ch. G. Habermann, US Cath. Soc. Monogramm, $7+131 \mathrm{p}$

${ }^{124}$ See Footnote 11 in John P. Snyder, op cit p. 367. The first to have experimented with these projections and world section views was Leonardo da Vinci, in c. 1490 as personally discovered in 2013.
} 
the publishing of the CI. This was only fully tested by H. Glarean (1488-1563) in his c. 1510 manuscript (Heawood, 1905: p. 652).

\subsection{The Lack of Quotation in the 1507 CI}

To underscore the aforementioned argument the 1507 CI printed in St. Dié does not, in contradiction to the CI from Lyon, refer to any printed globular map (Stuart, 2000: p. 19).

The spacious projections are not a globe but are 2 small supplementary maps, all on the same single sheet of paper, characterised by the lack of the North and South poles! In the dedication to Emperor Maximilian it is stated "..."I have prepared for the general use of scholars " $A$ " map of the whole world, like an introduction, so to speak, both in solid and on a plane": A map on one single sheet of paper.

The interpretation of the word "both" has led to the confusion of 2 maps meaning two sheets of paper.

Ringmann defines "solido" as corpus measured by a length, a breadth and a height ${ }^{125}$. In summary, a globe has none of these, and only has a diameter and a circumference. Ringmann refers to a certain Theodosius, which must be the Greek Astronomer and Mathematician Theodosius of Bithynia (c. 160 BC-c. 100 BC), author of the volume "Sphaerics", for a clear definition of a sphere but fails to refer to any kind of a globular map necessary to construct a globe $e^{126}$.

Now the connotation becomes clear. He does not say he made two maps, but only "A" (=one single) map. In what follows he describes what his purpose of the little volume is namely to write a description of THE world map.

Again, he does not refer to two maps, or to exemplars, or two variations. There is no description of a globe! The first to publicly state that the Latin Interpretation of the 1507 CI was erroneous was Prof. Dr. A. Elter (Elter, 1896: pp. 23-36) in 1896 in his lecture presented in Latin for the Bonn University with the title "De Henrico Glareano geographo et antiquissima forma "America" commentatio (Heawood, 1905: pp. 647-654). One key part of his Argument was the use of the wording "Globulo roduntro comparati ut spera solida" in the 1509 Edition of Globus Mundi printed by J. Grüninger in Strasbourg, instead of "tam in solido quam plano" in the CI 1507 version $^{127}$.

\subsection{Characteristics of Waldseemüller: His Cartographic Productions}

Waldseemüller was not the type of cartographer interested in making a small c. $800 \mathrm{sq} \mathrm{cm} \mathrm{map,} \mathrm{but} \mathrm{to} \mathrm{be} \mathrm{influ-}$ ential, and so he therefore made a huge map, for a huge Empire. No interest in a tiny even unassembled globe. The Globes for Popes and Emperors were adapted to their status. The globes were either big and mighty or small but expensive looking and they would have a stand and a dedication to the emperor on the globe, which this globular map and its woodcut copies lack!

\subsection{There Is No Reference}

There is no reference to any kind of woodcut globular maps in the "Globii Mundi" or its German Translation printed by J. Grüninger in 1509. Furthermore, neither H. Glarean nor S. Münster (1489-1552) draw any manuscript edition of woodcut globular map, or make any allusion to their presence in their elaborate manuscript writings (Bonn, Munich, J.C.Brown University Lib) of c. 1510 and c. 1515 (see Table 1 (A) and Table 1 (B)).

This is also the case for Johannes Schöner (1477-1547) (Holst, 1999), Lutheran as of 1525-1526 (Schmeidler, 2007: pp. 405-406), who fails to make any remark to Waldseemüller and any kind of earlier woodcut globular maps in his "Luculentissima..." printed in 1515 to accompany his terrestrial globe for which he copies Waldseemüllers world map as a layout (Maruska, 2008: p. 145). The historic event on October $31^{\text {st }} 1517$ of Martin Luther posting his 95 theses on the church door of Wittenberg had a key effect on the content of map making ${ }^{128}$.

\footnotetext{
${ }^{125}$ The phrase is "Solidus est corpus longitudine/latitudine/altitudine et dimensum" (Wieser \& Fischer, 1907: p. 38).

${ }^{126}$ The phrase is „Igitur sphaera (ut Theodosius in libro suo de spheris definit) est solida.” In English: "A Sphere, as Theodosius defines it in his book on spheres, is a solid and material figure bounded by a convex surface..." Fischer op cit. p. 39. I thank Dr. M. Lehmann for his mail dated 29.10.2014.

${ }^{127}$ I thank the expert Dr. Martin Lehmann for his kind mail dated 21.09,2014 for his reference to use of "globulus" instead of "solida" in the Globus Mundi.

${ }^{128}$ The name of Santiago de Compostella on the 1528 woodcut globular map attributed to the catholic Peter Apian excludes a Lutheran cartographer like P. Schöner.
} 
It may have speeded up the printing of small abridged woodcut globular maps.

\subsection{Erroneous Justification by Gallois Using a Dubious Source and Erroneous Citation}

The contemporary source, dated August $12^{\text {th }} 1507$ is a letter (Cod. Vat. Pal. Lat. 730) by Johannes Trithemius ${ }^{129}$ to this friend Wilhemus Veldicus Monapius.

It contains an allusion about a large plani globe map recently printed in Strasbourg. The aforementioned refers to a defined city for the printing "nuper Argentinae impressam" and therefore in contradiction, which Gallois admits, with Waldseemüller's definition of St. Dié as the printing place ${ }^{130}$.

In addition it refers to a beautiful small terrestrial globe, but fails to make a referral to any kind of accompanying explanatory booklet in the form of the signed Cosmographiae Introductio, which is a missing intrinsic element.

Therefore the description does not match the cartographic material described by Waldseemüller ${ }^{131}$. Basic elements such as a cartouche and a mounting, that the globe likely may have adorned are lacking in its content (Gallois, 1890: p. 49).

Interesting is that nobody commented on the very rough estimate of the grade mentioned in that particular letter: "Actually I purchased, however, a few days since at a low price, a beautiful small terrestrial globe ("modico sphaeram orbis pulchram"), and also a large scale planiglobe ("globum terrae in plano expansum") presented on a flat surface with the islands and areas that the Spaniard Amerigo Vespucci recently discovered in the Western Ocean down at about the tenth parallel"132.

This document fails to list the crucial names such Waldseemüller or Ringmann. Furthermore the description of, "islands and areas... about the tenth parallel" is not at all in accordance with the portrayal of the "islands and areas" as on the large Waldseemüller world map which has a much bigger land area. Finally, none of the above as described is listed in the detailed inventory of the Monastery. Instead, a globe with an explanatory booklet purchased July $8^{\text {th }} 1515$ is in the inventory ${ }^{133}$.

E.L. Stevenson notes that it has been thought by some that the beautiful globe referred to as having been purchased in Strasbourg was the globe of Waldseemüller (Stevenson, 1921: p. 67). This argument is based on wishful thinking by Avezac ${ }^{134}$ who is erroneously cited by Gallois ${ }^{135}$. This was particularly the case subsequent to the discovery of woodcut globular maps in the second half of the XIX century. It has been assumed that Italians such as the Tuscan Francesco Rosselli (1445-c. 1513) produced globes of different sizes prior to 1507 so it could well have been a beautiful Italian globe. The "epistolary evidence" (Ragnow, 2013: p. 6) is circumstantial, imprecise, in lack of substantiation and is surpassed by the evidence as presented above.

\subsection{The Lack of a Didactical Guide}

If Waldseemüller, who is an expert in mathematics and geodesy, is known for his big size maps, including the c. 1520 map edition of Europe, would have made globular maps, there would have been a didactical guideline for

\footnotetext{
${ }^{129} \mathrm{Just}$ as an example of another far reaching but erroneous conclusion based on this particular letter of Trithemius, I refer to Monike Pelletier who attributed the painted green globe in Paris to Martin Waldseemüller. I rebute this attribution as Waldseemüller only used "America" one time on his large map, and certainly never used it 4 times on painted globe. Second, on the base of the nomenclatura of the green globe that is characterised by Italian endings (on the Italian Peninsula). Third based on aspects of style and content such as the large circular terra incognita, the large unknown landmass on the north pole and the multiple passage ways between the northern and southern American continent. Last but not least, the diameter of $24 \mathrm{~cm}$ may reflect 5 Grazia (5/12) of the Italian Renaissance measurement of the Florentine Braccio reflecting an Italian (Tuscan) provenance of the Globe.

${ }^{130}$ See the Colophon on the H. Harisses examplar (Ex Libris: Nov. Eborac) from his library now kept at the LoC. http://www.loc.gov/resource/rbc.2008thacher16176/\#seq-113

${ }^{131}$ Galleries (1950), The World renowned Hauslab-Liechtenstein World Global Map of 1507 by M. Waldseemüller, Indiana University, 1950 p. 16.

${ }^{132}$ Van der Krogt, 1993, chapter 1.2 and Klaus Arnold, Johannes Trithemius (1462-1516), Würzburg Kommissionsverlag Ferdinand Schöningh, 1991.

${ }^{133}$ Würzburg, UB M.ch. f. 340, Wieland, Schottenkloster, p. 74. Nachlass des Abtes Mathias 1535 in Heinz Ludwig Arnold, Literatur Lexikon, Stuttgart, 2009, p. 215-216. I thank Dr. A. Schlechter for his mail dated 30.5.2014.

${ }^{134}$ What speaks in defence of Avezac was that he at the time of his publication in 1862 could not have viewed the large world map of Waldseemüller as it had not been discovered yet.

${ }^{135}$ L.Gallois cites Avezac on p. 49. He refers to p. 107 of Avezac, but "forgets" p. 110 and "forgets" in particular the fact that by the time that he wrote his PhD in 1892 that the copper engraved globular map had been discovered and there was mentioning in the CI printed in Lyon of printed globe having been seen by Boulengier.
} 
its use. Importantly a dedication on the globular map to the Emperor would have been added. As there is no bibliographical reference whatsoever, I am convinced that Waldseemüller's name was thankfully, but erroneously, used to fill a gap, with rather far reaching consequences in the history of cartography.

\subsection{Some "Forced" Argumentation}

Dr. Martin Lehmann, who concentrated more on the Latin translation of the work of Waldseemüller rather than on the geography of the world map, argues that the "Der Welt Kugel" printed by Johannes Grüninger (1455-1532) in Strasbourg in 1509 is written by Waldseemüller, and is a first "forced proof of the successive rejection of the giving of the name of America for the newly discovered continent by Ringmann" (Lehmann, 2008-2010: p. 160).

The poor quality, and the simplified depicted geography and erroneous "grading" of the gores (18 degrees instead of 15 degrees) of the world globe, which I analysed in greater detail, is a paramount argument against Waldseemüller's authorship. Waldseemüller was a geographer avant la lettre and the creation of major literary editions was not his primary concern.

\subsection{1. "Der Welt Kugel” (The World Globe)}

The authorship of "Der Welt Kugel" instead is in favour of a highly talented businessman named J. Grüninger, and the Medical Doctor J. Adelphus (c. 1480-1523), who may have identified a market niche for their readership.

The precision and advanced design of Waldseemüller's masterpiece map "Carta Itineraria Evropea", Map of Europe, was demonstrated by Dr. Kurt Guckelsberger, and proofs that Waldseemüller his standard of cartography was the highest among his contemporaries (Guckelsberger, 2013: p. 8).

\subsection{The Language Barrier and the Lack of Easy Accessibility}

German, Latin, French, Dutch, Portuguese, Spanish, Italian and English were required to be able to compare all the necessary sources for this research. In the XIXth century it was essentially only a combination of two or three languages.

\subsection{Mapreading}

The concentrating of map historians who date a map solely on the basis of locational accuracy in the mapping, thereby they omit the semiology of graphics and cartographic symbolization to understand these maps. Harisse acknowledges in his personal letter written on the first inside page of the binding of the CI of Lyon which he analysed, now kept at the JC Brown University Library that the content of the CI contains aspects of medicine and astrology which he does not understand ${ }^{136}$. One other example is the unnoticeable engraving of a fly just below the name of and to the right of the hat of Amerigo Vespucci on the large world map of Waldseemüller at the LoC. The fly is the symbol of Beelzebub (2 Kings 1:2-3). Knowing that the Worldmap was planned for engraving at a religious site at St. Dié, most certainly the engraver must have been impressed by the "demonious" cartographical discoveries and exotic passages regarding the intimate life and habits of the native population by Amerigo Vespucci as printed on the world map and in the Cosmographiae Introductio ${ }^{137}$.

\subsection{The Difference in Approach to Globes and Flat Maps}

Some only treat maps, others only work on globes. Both forget that they are basically the same, only the dimension differs.

\footnotetext{
${ }^{136}$ Henri Harisse, Handwritten note in the CI Copy of the J.C. Brown University bearing the H.H. Ex Libris.

${ }^{137}$ More recently, 2 Italian researchers have creatively discovered that the name of A.M.E.R.I.C.A. was perhaps based on the Acronym: “Ave Maria Eden Regina Ianua Caeli Ave” s. Diego Baratone, Claudio Piani, A.M.E.R.I.C.A 1507. La genesi del Nuovo Mondo, Monaco, LiberFaber, 2014. http://www.academia.edu/9400470/LA_POTENZA_DIMENTICATA_DEL_SACRO_NOME_AMERICA Partially they base their findings on a Painting of the Holy Mary by Domenico Ghirlandaio (1449-1494), from c. $147 \overline{2}$ in the now Franciscan Ognissanti (All-Saints) Church in Florence. In that fresco in the Vespucci Burial Family Chapel the young Amerigo Vespucci is depicted as a child with the rest of his family below the protective mantle, after the style of Andrea del Verrocchio (1435-1488), of the Madonna della Misericordia http://upload.wikimedia.org/wikipedia/commons/4/4b/Domenico ghirlandaio $\% 2 \mathrm{C}$ madonna della misericordia $\% 2 \mathrm{C}$ ognissanti\% $2 \mathrm{C}$ Firen ze.jpg They may have forgotten the fact that Martellus, whose world map design was copied by Waldseemüller, created his world map prior to the discovery of the new world and that he was influenced by the projection of Ptolemy.
} 


\subsection{The Lack of Both an Interdisciplinary Approach and of Applied Mathematics}

The other 2 copper engravings were as relevant as the globular map, but until now nobody even inspected these. The string of samples of globular maps, small maps and globes all intended for a c. $11 \mathrm{~cm}$ globe, must have rung a cartographic bell, which it did not.

\subsection{Stemmatics}

The use of a methodological approach as in the theory of K. Lachmann is rarely practised in detail and was replaced by a superficial approach leading to erroneous conclusions.

In short, a long chain (1-25) length of flaws, misinterpretations and repetitions which for years have filled numerous volumes on the history of cartography.

Preceding, the final conclusion, the above findings lead us to a few remaining questions:

Why does the powerful Robertet, who had a famous collection of medical volumes in his private library finance a Motus none Spere which basically is a horoscope and the Astrolabium Physicum, which is an iatromathematic astrolabe ${ }^{138}$ ? A subsequent question is:

Did he in the name of King Louis XIIth also order the making of the Astrolabium Physicum and the World Map in a globular map format? What did he want to know?

Did he want to know the particular future of the younger son of the Duke of Lorraine René II (1451-1508), Louis de Lorraine, Count of Vaudémont, born in Bar-Le-Duc (48 ${ }^{\text {th }}$ degree) on April $27^{\text {th }} 1500$, who as his father attempted to secure his hereditary claim to the throne of the Kingdom of Naples (Duclot 1806, 266). His father had been "surpassed" in this claim of Naples by the French King Charles VIII (1470-1498).

Or did he want to have a false horoscope cast, in order to eliminate a competitor, as the Lord of Croy had fixed up for Duke Charles the Bold in Bruges in 1468 (Vaughan, 2004: p. 248).

I believe it was none of the above, but a simple other reason, to which I come at the end. First I continue with an analysis of the other 2 copper engraving which may have been too high a hurdle for many map historians in the past.

\section{The Astrolabium Physicum, Guillaume G. de Wissekerke, His Endeavors, the Discovery of America and the Role of Astrology}

\subsection{The Medical Astrolabe}

The work on Astronomy by Ptolemy, who acknowledged that the predictive power of astronomy for the motion of the planets and other celestial bodies is to be ranked above astrological predictions, was energized by the wish, like all astronomers, to be able to easily calculate the movements of the planets (Hoskin, 1999).

The ancient Greek concepts of Macrocosm and Microcosm were the basis for the operating of early western astronomy. Medical astrology (Brosseder, 2014: pp. 406-426) related the movement and situation of the planets and other objects in the celestial sphere to medical operations. This in turn allowed for the study of astronomy. (Evans, 1998) ${ }^{139}$.

In order to treat a patient, the physician needed to cast the nativity of his patient. He could do it the long way using computational tables or the short way by using an astrolabe, supplemented by astronomical tables. A prerequisite to correctly check on the transit of the planets was the correct rectification of the above specified tables in accordance to the meridian of the location of the patient. A major source of inaccuracy was the timing based on unreliable clocks. As early as 1260 weight driven clocks were more reliable than water driven ones (White, 1978: p. 334).

The only person that published during the Renaissance about an Astrolabium Physicum was Guillaume Gilliszoon de Wissekerke (Figure 4: Astrolabium Physicum). A medical astrolabe is a computational instrument to determine optimum times for medications and bleedings. It is about a method to be able to easily calculate the movements of the planets and to associate it to medicine. As stated by the late Prof. Dr. Emmanuel Poulle (Poulle, 1961: p. 224) ${ }^{140}$, it was Guillaume Gilliszoon de Wissekerke, originating from Zealand, from the county of Flanders, now part of the Netherlands, who published about this instrument. I now have a closer look at it.

\footnotetext{
${ }^{138}$ I am grateful to Univ. Dr. Helmuth Grössing for his personal mail dated November 15th 2014.

${ }^{139}$ I refer to Evans (1998), James. The History and Practice of ancient astronomy. New York, Oxford Univ. Press, 1998.

${ }^{140}$ For the Motus Spere see also MS Latin 7276B in the French National Library.
} 


\subsection{Guillaume Gilliszoon de Wissekerke and His Endeavors}

The trace in this research with regard to the Astrolabium Physicum unmistakenly leads to this Wissekerke, a Medical Doctor, highly talented in mathematics. Many of the greatest Medical Doctors were attracted to work at courts, as was Wissekerke from Zeeland. Medical astrology exerted great influence (White, 1978: pp. 311-312).

As reported by Dr. Monica Azzolini, medical astrology progressively rose during the 1490s and 1490s to higher prominence within the courtly medicine but also as a political discipline, for example at the court of Ludovico Sforza. The aforementioned was miraculously saved from death by the physician-astrologer Ambrogio Varesi da Rosate (Azzolini, 2013: pp. 17-18).

Wissekerke's name has many variants. The Library of Congress lists seven ${ }^{141}$. He is also known as Guillaume de Carpentras (Wickersheimer, 1979: p. 103), or Willem Gilliszoon, or Willem Gillisz Van Wissekerke, or Aegidii, Guilielmus de Wissekerc or Gulielmus Zelandinus. Coincidentally, there is also an old castle named Wissekerke near Rupelmonde (birthplace of Mercator) in Flanders.

As so many, he is rather forgotten in the history of science and even more in the history of Cartography. But this paper may even change this.

One variant of his name is Guillermu Egidii de Wisselrerc ex Zelandia, in the Colophon of the work with the title "Equatorii celestis motus siue calculo canonu. Expositio Guillermi Egidii de Wisselrec Zelandi Ni feliciter incipit". The colophon reads: "Equatorii celestis motus expositio" and is dated Lyon, 1511. Wissekerke wrote this booklet on the topic for which he was known namely the easier calculation ${ }^{142}$ of the celestial movements.

A small printed volume, of which the cost of printing is paid for by non other than the above specified "Ludovici Bolengier albian ciuis. Lugdini impressi” (Marcel, 1889: pp. 171-172). In English: Louis Boulengier, citizen of Albi, printed in Lyon.

Wissekerke is known to have been the author ${ }^{143}$ of "Liber Desideratuss" ${ }^{144}$ published in Cremona in 1494 with the colophon "Liber desideratus Guil De Carpentras Astrol."

\subsection{Wissekerke and the Discovery of America}

Wissekerke is one of the first known to mention among a long list of geographical names and their degree of parallel, a single one which refers to" vulgo hyspanico dicta laguinea". This citation is printed only one year after Columbus return to Spain in 1493. This signifies that the author was very well informed and that Wissekerke's typesetting work was updated shortly prior to its printing.

There is no evidence that Wissekerke is the author of the phrasing "America noviter reperta", prior to its printing in Globii Mundi in Strasbourg in 1509, and on the mounted brass Jagellonian Globe (King, 2014: pp. 16-32) c. 1510 (see also Table 4 for the transcription) as part of an armillary sphere instrument of French origin, kept in University Library of Krakow.

Columbus his letter on the first voyage, the recent discoveries of unknown islands...named Spanish "GUNEA" (https://archive.org/stream/ita-bnc-in2-00002280-001\#page/n36/mode/2up).

This reflects "Isla Juana" the first name of Cuba, after the Spanish Infantin Juana ${ }^{145}$.

Wissekerke as Galileo were influenced by the scheme to make horoscopes developed by Julius Firmicus Maternus, $4^{\text {th }}$ century, in Matheseos Libri VIII on Astrology ${ }^{146}$.

Wissekerke, his French name was Guillaume de Carpentras, constructed astrological spheres from which horoscopes were drawn. The name and location of Carpentras are relevant.

It was the place where the Bishops of Carpentras, amongst them, Giuliano della Rovere (1471-1472), the later Pope Julius II, as mentioned earlier, were protectors of the arts and scientists. What about Wissekerke and As-

\footnotetext{
${ }^{141}$ An Egidio de Wissekerke is listed in 1412/1415 among the German Students in Bologna. In 1440 an Egidius de Wissekerke is accepted as a professor in law at the University of Louvain. Dr. P. Meurer (mail dated 1.7.2013) thinks the latter may be the father of the Medical Doctor and Author Guilielmus de Wissekerke. See. Deutsche Studenten in Bologna (1289-1562) Biographischer Index zu den Acta nationis germanicae Universitatis bononienses. Bearbeitet von Gustav C. Knod, 1899, p. 639.

${ }^{142}$ Antother contemporary work, including the $13^{\text {th }}$ century horoscopes or so called "figure celi" by Pietro d'Abano, was by Johannes Angelus (1463-1512), Professor in Vienna and Ingolstadt, who in 1502 published his Astrolabium planum in tabulis ascedens..... in Venice (Newberry Library Wing ZP 535. G 43).

${ }^{143}$ Guilelmus \& Gilliszoon de Wissekerke (1494). Super caelestium motuum indagatione sine calculo, Carolus de Darlerius, Cremono $1494 / 1495$

${ }^{144}$ Van Wissekerke (1965). Liber Desideratus, 1494, Reprint in Dutch Classics on history of Science, Publ. P. De Graaf with an Introduc. By D.J. Struik, 1965

${ }^{145}$ I thank Dr. Peter Meurer for this solution. Personal mail dated 15.07.2013.

${ }^{146}$ I thank Prof. Dr. Vanni Gorni for this mentioning. Personal mail dated 22.07.2013.
} 
trology? This is answered in the next paragraph.

\subsection{Wissekerke and the role of Astrology}

I found Wissekerke as an astrologer and maker of clocks, in the form of a round apple, in Aix en Provence. He was in Lyon in 1476. In 1477 he was back in Aix en Provence where he worked for the René of Anjou, Duke of Lorraine (1409-1480) and titular King of Naples. René of Anjou, father of René II from Lorraine, later benefactor of Martin Waldseemüller, bought from Wissekerke in 1479 a highly decorative square "cadran" or a type of sundial made for all climates ${ }^{147}$. In 1488 Wissekerke was in Milan where he demonstrated and "left" a planetarium to the Duke of Milan Gian Galeazzo Sforza (1469-1494).

In 1492 Wissekerke presented a "spera regalis", which contained many parts and was designed so that all the movements of all the planets, at any hour of the day or night, could be observed with it, to the French King Charles VIII (1470-1498).

The latter had just, upon turning 21 years old, become the French King in 1491. The next trace is the above cited when his printing costs of a volume are being paid for by his benefactor Louis Boulengier in 1511 .

The famous Belgian Cartographer Gerhard Mercator (1512-1594) from the County of Flanders quotes Wissekerke (Ceradini, 1894: p. 50) ${ }^{148}$. Castle Wissekerke is adjacent to Rupelmonde, birth place of Mercator.

Foremost there exist only one Astrolabe Physicum (see Appendix 3) made by Wissekerke (Severino, 1997: p. $47)^{149}$, with the exact coordinates (48 gra (duum) et 38 minutorum) for Fontainebleau and it is kept in Paris in the National Library. Of interest is the binding (Planche VI) of King Henry II (1519-1559) whose father was Francis I of France (1494-1547) from the house Valois-Angoulême. In other words, this is clear evidence that there is a link between Wissekerke and the founder of the Royal French House of the Valois-Angoulême.

King Francis I his favourite residence was the castle at Fontainebleau, leaving no doubt for the coordinates. The latter succeeded his cousin and father in law Louis XII, from the house Valois-Orléans, who, as I quoted earlier, died without a male heir (Laffitte, 2003: pp. 221-230).

The Astrolabium Physicum at the NYPL has in the middle the sentence "DOMUS CELI PRO 45. GRADIBVS FABRICATE". The Number 4 is inverted and has an emblematic signification. It means: that the printing is executed in accordance with the best working practice. Other similar cases are the Printing Symbol of Guillaume Balsaria, Librairie Imprimeur Lyon 1493-1630 and Librairie Droz.

\section{The Horoscope for the $45^{\text {th }}$ Degree parallel 150 , the French King Francis I and the Arrival of Leonardo da Vinci in France in 1516}

Lyon was by all means a very large and significant printing centre. It had a reputation for making unauthorised copies. The fact is that the date of c. 1510 as the erroneous beginning of the printing practice of Jean de La Place as a justification for the date of the printing of this globular map, as already mentioned lacks any substantiation. Jean de la Place who is also Johannes de Plateae was known as a printer in Lyon as early as $1498^{151}$.

More relevant is the evidence that the Astrolabe is constructed for it to be applied on the $45^{\text {th }}$ degree and it was found together with the Motus none Spere. To cast a horoscope the knowledge of the place and hour of birth is a prerequisite.

A few crucial cities are located on that parallel. They include Lyon, Puyen Vallais, Certosa di Pavia (near Milan), Montbrison and Venice, but also the city of Cognac, which was the birth place of the French King Francis I (September 12 $\left.2^{\text {th }} 1494\right)$.

I believe the two copper engravings were constructed on behalf of Florimond de Robertet, powerful secretary of the French King Louis XII. The order for the horoscope was likely influenced by the superstitious attitude of Louise of Savoy (1476-1531), mother of Francis I52.

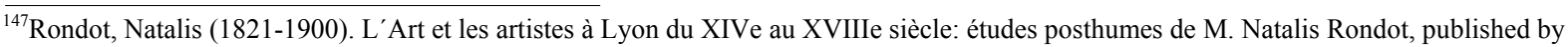
Alfred Cartier and Léon Galle, 1902. Footnotes 2-5.

${ }^{148}$ In addition: Silvio A. Bedini and Francis A. Maddison, Mechanical Universe, The Astrarium of Giovanni de Dondi

${ }^{149}$ This was confirmed by the Director of Research of the C.N.R.S., Dr. Jean-Pierre Luminet in a personal mail dated 14.07.2013.

${ }^{150}$ The Motus none Spere is set for the year AD 1500. Around 1500 trepidation was reaching a maximum effect, which according to Prof. Dr. Owen Gingerich from Harvard means that the system was near collapse and was no longer making the total precession approximately correct. Mail received dated 9.05.2014. A coarse volvelle indicates 1500 (on a total duration of 7.000 years)

${ }^{151}$ I thank the director of the printing museum in Lyon, Pierre-Antoine Lebel, for his explanatory mail dated

24.11.2014.https://archive.org/stream/histoiredelimpri00vinguoft\#page/134/mode/2up/search/johannes

I discovered the Grammatica by Jurenalis Gvido, printed by J.de la Place 6.VII.1509 in the Ukrainian National Libary.
} 
The horoscope may have been important in order to know the future of the new foreseeable "boss" and his future career as the successor of Louis XIIth.

One of the prerequisites of becoming a King in France, other than the heritor proof, was the minimum age of being 21. The House of Valois-Angoulême was not expected to inherit the throne as Charles VIII was still a young king, until when he died childless in 1498, and was succeeded by Louis XII.

At this moment, Florimond de Robertet knew that unless Louis XIIth had a male heir, the next king, at the latest (taking into account a period of regency), at the age of 21, one year after 1514, would be Francis from the House of Angoulême. This is the logic why the date of 1514 is printed 3 times on the Horoscope, so specifically planned for the year 1514 .

In light of the probable change of course, after the early death of Charles VIII, from a House of Valois-Orléans to the House of Valois-Angoulême and a very young and inexperienced king, this seems quite natural.

The horoscope was therefore not made constructed for the "old" King Louis XII, who was not successful in fulfilling his dynastic mission i.e. to have a male heir. Louis XII was suffering heavily of gout, a medical condition known for the recurrence of acute inflammatory arthritis.

The latter illness could be treated by using the Astrolabium Physicum, i.e. Medical Astrolabe which had a blood letting ${ }^{153}$ schedule. Symptoms of the exceptional hereditary and "royal" illness Porphyria have often been misdiagnosed as "gout" (Bos 2005, Footnote 6). The CI version Nr. 2 (KB+++1517) which had, as we have seen, the three copper engravings loosely inserted in it, has a compelling contemporary four word phrase in faint writing "Ad usum Porphyrii rufinii" (red urine was a symptom of Porphyria) penned on top of the edge of the title page (Figure 9) on it $^{154}$.

And this may be why the second engraving was intended for Florimond de Robertet himself, turning 55 in 1514. He was born in Montbrinson which is on the $45^{\text {th }}$ parallel, a prerequisite to apply the Astrolabium Physicum.

But King Louis XII was not born on the $45^{\text {th }}$ parallel degree. Neither was he born around c. 1500 for which the mater of the astrolabium physicum was constructed. In addition, the royal insignia of a ruling king would not be missing if it were constructed for a ruling monarch.

As the Cosmographiae Introductio printed in Lyon has a clear medical connotation, I propose this interlude to include this relevant aspect.

I believe that the "praef. Descolis"155 mentioned in the CI edited by L. Boulengier, could be the "maitre

\footnotetext{
${ }^{152}$ While Louise of Savoy was Regent of France (1525-1526) in the absence of King Francis I who was at war in Italy at the battle of Pavia, she asked in 1525 one of her medical doctors, the famous astrologer of German origin, H.C. Agrippa, to continuously make a horoscope of her son King Francis I. Instead of doing so, he foresaw that the King Francis I would lose the war in Italy, which did occur. In Orsier (1911) Henri Cornélius Agrippa: sa vie et son oeuvre d'après sa correspondance (1486-1535), Bibliothéque Charcornac, Paris, 1911, p. 24.

${ }^{153}$ I thank the Vesalius Expert Dr. M. Biesbrouck for his mail dated 30.11.2014 and his reference to the Encyclopaedia Britannica, 1973, vol 18 , pp. $250-251$.

${ }^{154}$ I thank librarian Ms. Meridith Mann from the Rare Books Division of the NYPL for her mail dated December $5^{\text {th }} 2014$ and the pictures of the faint message of Copy 2. Curiously, Copy 1 of the NYPL has on its last page a glued on woodcut print of an onomatic medical disk. Johannes de Mirfeld is known to have developed this method of forseeing the future of a patient. In short: The number of the letters of the name of the patient, the number of the letters of the messenger who summoned the physician and the number of the letters of the day upon which the messengers first came to the physician, taken all these added up and if a even number results, the patient will not die, if uneven he would perish. See: Sir Percival Horton-Smith \& Aldridge (2013), Johannes de Mirfeld of St. Bartholemew's. Smithfield: His life and works, Cambridge University Press. 2013, p.71. This medical prognostication was discussed by Agrippa in his "De Occulta Philosophica", the manuscript of which was completed by Agrippa in 1511. The first edition was printed in Basle in 1535. In 1578 Georg Pictorius partially copied Agrippa and published a onomatic medical disk, which is identical with the cut-out glueed in Copy 1 of the CI Lyon Version in the NYPL, under the heading "Epitome"'’De Onomantia. Cap.XIIII" on p. 593. Thanks to Prof. Dott. Vanni Gorni, mail dated 9 and 10.12 .2014 it was possible to identify the source of the cut out of the disc on the CI Copy 1. (ZV 263. ULB Sachsen-Anhalt and Nb 359a in Berlin)

${ }^{155}$ There is a certain Medical Doctor named Jean Delecouls, who apparent from his letters is very educated and uses a ciseronian Latin. He exerts the function as a consul in Albi between 1514 and 1515. He belongs to a consular and well respected bourgeois family. But he is neither a professor, nor a praefect, and the type of Latin used in the CI is not ciseronian (which is also conceded by O. Cabayé op. cit. p. 27 who cites Pierre Mason, Sur quelques notes manuscrites d'un éphéméride, Revue du Tarn, Albi 1904, p. 209), as it is more or a modern type of Latin including the S.P.D. (Salutem Plurimam Dicit). Furthermore, the difference in spelling between "DESCOLIS" to "DELECOULS" is rather significant, the medical concepts expressed in this paragraph and the one at the ending of the CI are typical for a humanities professor as they include didactical aspects, in general and aspects typical from the medical treatise such as De Medicina by the Roman A. C. Celcus. (first printed Edition, Florence 1478).
} 


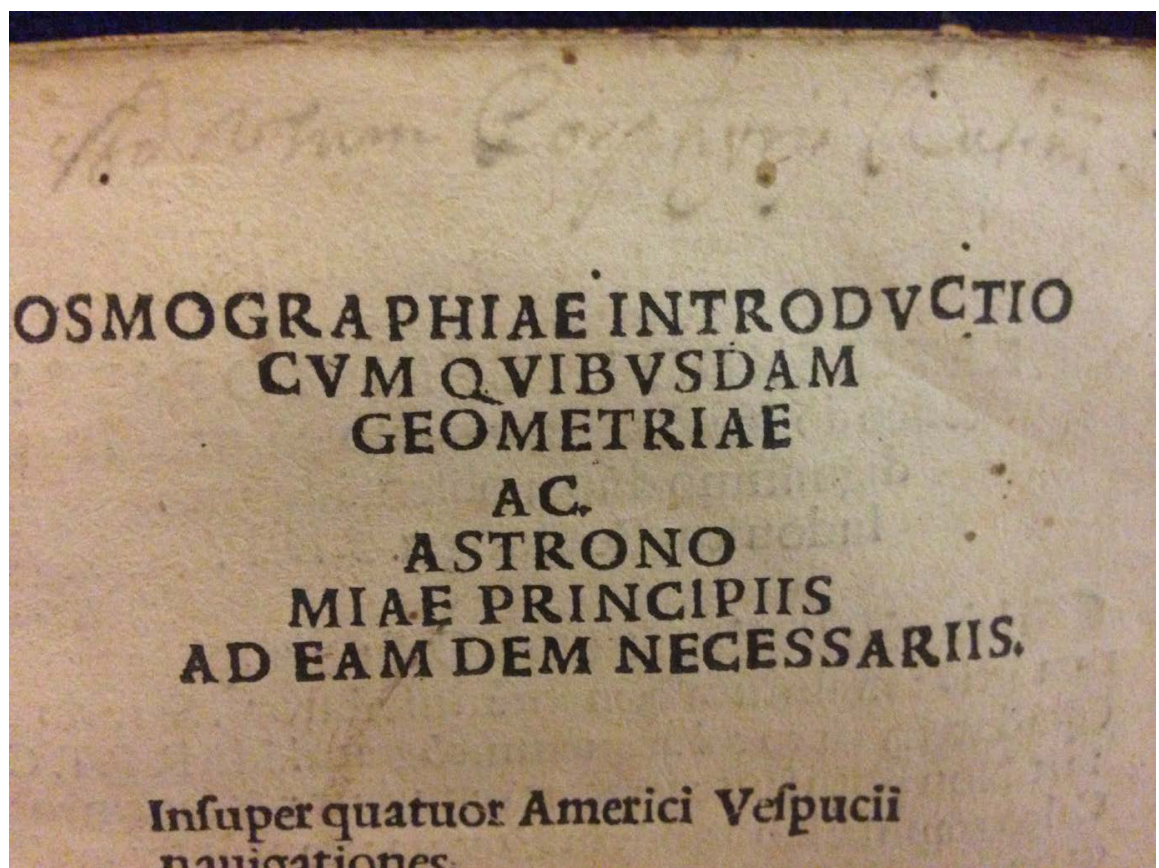

Figure 9. Copy 2 of the CI at the NYPL with the hand written inscription of “Ad usum Porphyrii Rufini” above.

Descolis", Prelate, Humanist and Latin teacher, in analogy to the Italian born Humanist and Cartographer Peter Martyr (1457-1526) tutor to the children of the King Ferdinand and Queen Isabella of Spain (Schwartz, 2007: pp. 51, 129). In none of the bibliographical references and sources that were consulted it was possible to identify a medical doctor or professor with the name Descolis ${ }^{156}$.

In contrast, I perceived that "Descolis" might be a kind of professional title such as used for Francois de Moulins de Rochefort (c. 1465-1526) underestimated and humble Franciscan teacher of humanities ${ }^{157}$, since 1501, of the young Francis (Tilley, 1994: pp. 5-7), Count of Angoulême, prior to becoming French King ${ }^{158}$. In this case the globular map could have been a teacher's didactical tool ${ }^{159}$ for a youngster ${ }^{160}$ which inspired the adventurous Humanist Renaissance King of France.

Apparently, Franciscan influence including by Pope Sixtus IV, the Franciscan Grand Almoner Francois de Moulins de Rochefort and others played a key role during the age of discoveries. One may recall that Columbus was accompanied on his second voyage to the New World by Jean de la Deule and Jean de Tessin, two Franciscan Lay Brothers from Belgium ${ }^{161}$.

As to the 1505 watermark ${ }^{162}$ found on the volume of the CI from the city Library of Lyon (and on the volume at the CI Lilly Library in Indiana) it is a contemporary element and factual piece of evidence. The discovery of a hand written phrase below the Colophon "impressam 1507" on the CI volume of the Lilly Library in Indiana is

\footnotetext{
${ }^{156}$ I thank Dir. Pierre-Antoine Lebel who amongst others checked the bibliographical Reference Book by the Brothers Baudier. Mail dated 24.12.2014. No reference was found in Ernest Wickersheimer Dictionaire.

${ }^{157}$ I refer to the PhD by Charlotte Bonnet:http://www.cesr.cnrs.fr/masters_doctorat/doctorat/theses-en-cours/charlotte-bonnet. She mentioned that Francois de Moulins de Rochefort referred to himself as the "the poor Socrates", but mostly used Desmoulins, Demoulins De Moulins and Rochefort. It is not known that he published on Medicine. Mail from 14.01.2015. The humility and the likely use of a pseudonym was confirmed by the author of Gratien by mail, dated 12.1.2015.

${ }^{158}$ Gilles Polizzi, dans Bibliographie d'histoire de l'éducation francaise,, Titres au cours de l'année 1993 et suppléments des années antérieures, par Isabelle d'Avelange, INRP, Paris, 1003, parut Education, apprentisage, initiation au Moyen Age. Acte du premier colloque international de Montpellier, Université Paul-Valéry, t.2, pp. 369-395// Les "Hiéroglypes" de Francois Demoulins: le Poliphile, modèle de l'éducation du prince, Traité sur les virtues cardinals” (BNF ms fr 12247) datant de 1509,, attribué à Francois Demoulins, „,maistre descole" du futur Francois 1er. Hypnerotomachia Poliphili or in English Poliphilo's strife of courtly love in a dream was first published in Venice in 1499 by Aldus Manutius. Athough its genre is romance, it makes, by way of comparison frequent references to classical geography and mythology. See also: Lefaivre (2005: p. 257).

${ }^{159}$ I refer to the volume by J. Hessler with the appropriate title “A Renaissance Globemaker's Toolbox”, Loc, D. Giles Ltd., London, 2013.

${ }^{160}$ I refer to one other example i.e. by A.E. Burkhard von Birkenstein, Erz-Herzögliche Handschrift des Circuls und Lineals, Wien, 1686. This educational aspect of a young king is underlined and supported by Univ. Prof. Dr. Koenraad van Cleempoel (Personal meeting in Antwerp on 28.12.2014).
} 
supplementary aspect which has been overseen ${ }^{163}$.

The most conclusive is the imprint of the year 1507 in the content of the Cosmographiae Introductio (Figure 10).

It was this King, Francis I full of youthful love of adventure and a desire for military glory (Setton, 1994: p. 159), who, with the assistance of youth friend the French Grand Admiral Guillaume Gouffier de Bonnivet (c. 1482-1525) had convinced Leonardo da Vinci to finally come to France in 1516.

Leonardo da Vinci's involvement with the principle of the construction of ports including the one in Le Havre has been proven. ${ }^{164}$ It was this young French King who recognised the importance of the times and built the Port of Le Havre in 1517, initially named "Franciscopolis", and in 1524 helped, with a royal guarantee (Hamon

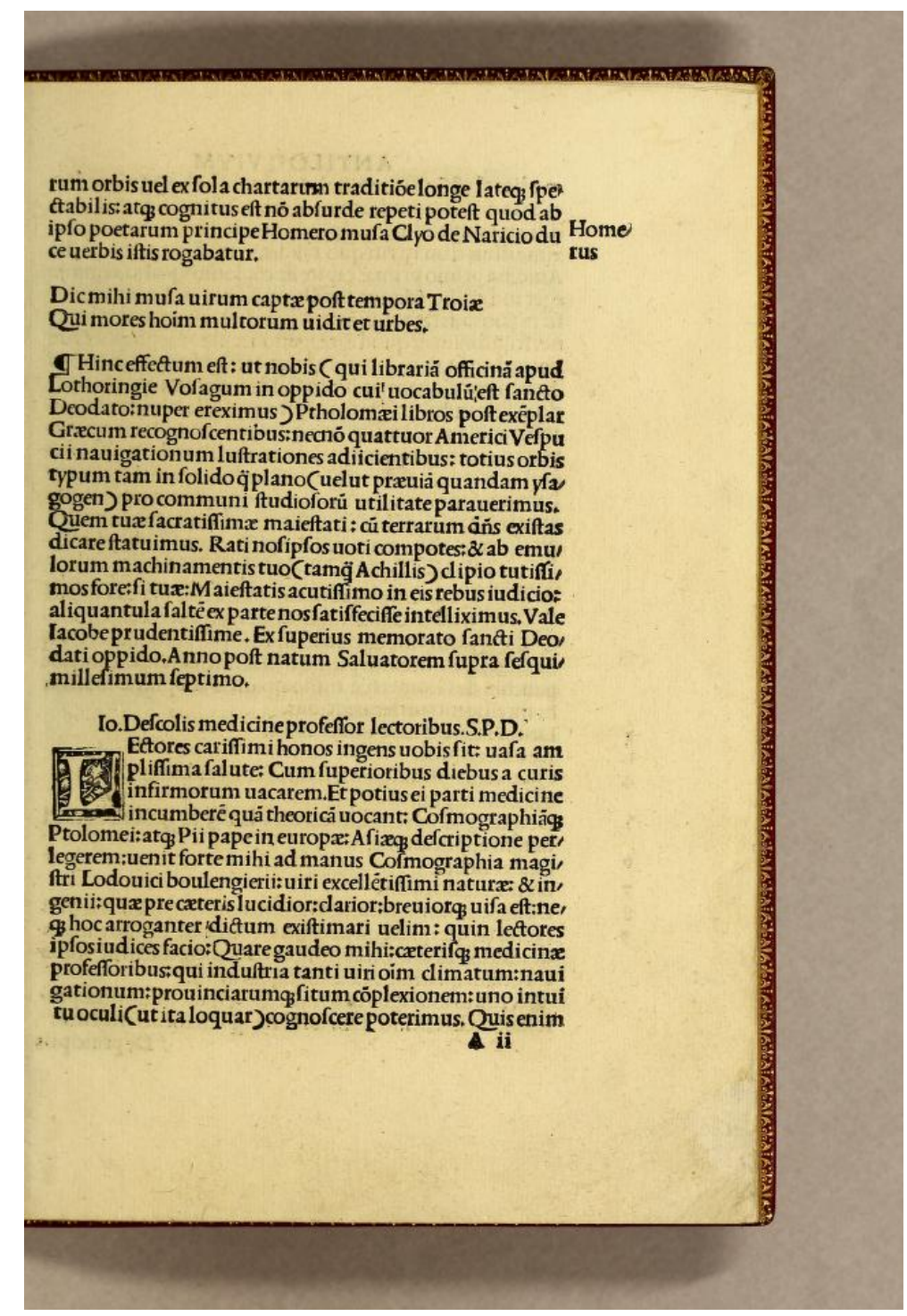

Figure 10. "Salvatorem supra sesquimillesimum septimo": The date of 1507.

\footnotetext{
${ }^{161}$ I refer to http://www.christusrex.org/www1/ofm/fra/FRAmis03.html

${ }^{162}$ According to Denis Peaucelle who consulted other experts like Benoit Du Fournier and Mrs Josette Telford, the major source of paper for Lyon, due to its high cost of production and transport, came from the Auvergne region. Finding paper with a paper mark Angouleme does not mean it was actually made in an Angoumois paper mill. According these sources no paper mark with a letter B as on the CI of the Lilly Lib and the Lyon version with a date of 1516 or 1517 was found! I thank AFHEPP-President D. Peaucelle for his mail dated 11.01.2015.

${ }^{163}$ I thank the librarian Sarah Mc Elroy Mitchell from the Lilly Library, Indiana University, for her kind mail and picture as evidence dated 2.1.2015.

${ }^{164}$ Pascal Brioist, Romano Nanni, Leonardo's French Canal Projects, Vinci-Closluce, Footnote 9, page 98.

http://www.vinci-closluce.com/fichier/s_paragraphe/8729/paragraphe file_1_en_canal_projects.p.brioist_r.nanni.pdf
} 
1994: Footnote 31) the Italian and in particular the Florentine merchants and money lenders, expatriates in LYON, to finance the expenses of the expedition of G. de Verrazzano (1485-1528) to the Americas (Thrower, 1979: pp. 59-65).

It was during this expedition intended to find a sea passage to the Pacific and to China (Bruscoli, 2013: p. 128), as is depicted unequivocally on this globular map, that the location of the future city of New York on the Hudson River was explored. The anchor was dropped in the New York Bay on April $17^{\text {th }} 1524$ (Shauger, 2008, $1)^{165}$ by the Florentine, expatriate in Dieppe, Giovanni de Verrazzano. He sailed the ship named "La Dauphine" (named after the young child Francis III born in 1518). The French Captain of the Carrack which could hold 50 people was Antoine de Conflans ${ }^{166}$. New York was then baptised New Angoulême ${ }^{167}$, after the patron King Francis $\mathrm{I}^{168}$ his title of Duke of Angoulême, prior to becoming King. And it is precisely in New York ${ }^{169}$, thanks to H.C. Kalbfleisch from Brooklyn that the birth certificate of America, some 490 years later is stored in a small inconspicuous box, in the Rare Book Division of the New York Public Library.

As if Henry Harisse, who selected "Nov. Eborac" (New York) for his personal Ex Libris, had known all from the beginning. His Ex Libris forms part of the Latin quotation on the Seal and in the middle of the Flag of the City of New York: "SIGILLUM CIVITATES NOVI EBORACI".

\section{Conclusions}

The first conclusion is linked to the evidence that the only surviving reprint of the big Waldseemüller Map on display in the Library of Congress lacks a firmly accepted date. It is now widely accepted to be a later than 1516 galley proof. Even though the original woodblocks may have been worn, the age of the woodblocks is not relevant as they are not extant and therefore the large formerly unassembled map no longer bears the title of "the birth certificate of America". A birth certificate mandates the inclusion of a name and a date. Therefore, this small globular map at the NYPL with the name "AMERICA NOVITER REPERTA" and with the "terminus ante quem" (limit before which) of March $8^{\text {th }} 1508$ "has taken over" this status as being America's birth certificate.

A second conclusion is the validation of the hypothesis that this globular map is the Editio Princeps. The so called pseudo Waldseemüller woodcut globular maps were first copied much later as an overly simplified spin off from this copper engraved globular map. The transcription of the recently exposed woodcut globular map at the UB Munich, as an intermediary, allowed for the verifiable evidence and this conclusion.

The next hypothesis which was tested was the issue of the coincidence of the sizes of the 2 extant globes and the 6 ( 1 copper engraved globular map and 5 woodcut globular maps). This hypothesis could be statistically confirmed. This test also adds credence to the evidence of the c. 11-c. $11.5 \mathrm{~cm}$ Tuscan origin and the Ostrich Egg prototype globe.

There is no doubt that the Italian Renaissance is a source for transfer of knowledge to France in general and to Albi, Lyon, Amboise and Lorraine in particular in the field of architecture, arts, but also in the field of scientifica including large maps, like the Martellus as a layout for the geographical work of Waldseemüller but also for small ones, as proven from the genre history shown on the copper engraved world map and the other 2 copper engraved prints.

Directly following the aforementioned third conclusion is the verification of the hypothesis that there is no evidence that Waldseemüller is known to have made any globular maps.

He is known for his big size maps instead. As the evidence is conclusive, this means to have a historic prototype, now kept at the NYPL.

The next conclusion is that Germanus can be attributed as having drawn the layout of the globe gore map. In contrast Wissekerke, the inventor of the Astrolabium Physicum can now be attributed to have prepared the astrolabium physicum and apparently the Motus none Spere for the Commercial Publisher Louis Boulengier. There is no evidence that Wissekerke meets with Donnus Nicolaus Germanus. Political astrology, astronomy

\footnotetext{
${ }^{165}$ http://www.newyorkmapsociety.org/FEATURES/SHAUGER2.HTM

${ }^{166} \mathrm{http}: / /$ histoirededieppe.chez.com/relati00.htm

${ }^{167}$ Verrazzano's brother named Girolamo Verrazzano who formed part of this expedition was a cartographer. He made a planisphere, dated 1529, kept at the Library of the Vatican. Code Borgiano I.

${ }^{168}$ Charpin-Feugerolles (1893), Les Florentins à Lyon, Librairie ancienne, Lyon, 1893, p. 194.

${ }^{169}$ Subsequently New York was named New Amsterdam. This was followed by the name giving in the honor Duke of York, later King James II. I refer to my article on the royal silver and gold gilt Cyborium of the last English Catholic King James II-VII of c. 1695 in the Portolan, Spring Issue (2012) nr. 83.
} 
and cosmography ("geography") were not viewed separately in Renaissance.

Lastly, it is not a coincidence that the 3 copper prints are found loosely inserted in the CI Lyon Edition. This volume has the intact monthless date on page Aii intentionally left untouched. It reads "Anno post natum Salvatorem supra sesquimillesimum septimo" ( $A C$ 1507) from the same year in which the CI was printed in St. Dié namely 1507.

The CI from Lyon, of which I can locate at least two different editions, is not from as late as c. 1518 but, as the contemporary evidence in the form of the printed letter by M. Waldseemüller making an unmistakeable quotation to his Cosmography being copied, proves, from c. 1507. This is endorsed by the printed reference in this French Edition to the Duration of the length of the day and night as engraved on this singular globular copper engraved known map worldwide.

The author attributes the globular world map, found inserted in a surprisingly censored but dated $1507 \mathrm{CI}$ printed in Lyon, to Donnus Nicolaus Germanus. He was the most influential globe maker, astrologist and geographer of the Italian Renaissance. Last but not least, conclusive evidence was presented that the Lenox Globe, kept at the NYPL, and the Ostrich Egg globe played a key role in the early history of cartography as their scale and diameter, as calculated by Leonardo da Vinci, were being applied to print globular world maps from Italian sources to France and later to Germany.

The oldest and unique historical treasure in the form of a birth certificate of America is not a big assembled map in Washington, but a small sized copper engraving in NY. It is stored but not displayed at the New York Public Library ${ }^{170}$ only about $1 / 4$ mile away from the big river discovered and mapped in 1524 and now called the Hudson River. After finally getting back home by C.H. Kalbfleisch, so many years ago, this American treasure map is now reappraised.

\section{Acknowledgements}

I would like to thank the following people who have assisted in making this research possible, either by providing long forgotten literature, or proofreading, or suggestions, or just support. These include:

Univ. Assist. Dr. Petra Svatek, Research Expert Chet Van Duzer, Portolan Expert Richard Pflederer, Dr. Georg Zotti, Astrolabe Expert President Jan De Graeve, Lafreri Expert Pierre Dumolin, Librarian Kyle R. Triplett from the NYPL, Ancient Clock Expert Marisa Addomine, Dr. Kurt Guckelsberger, Dr. O. Cabayé, Dr. Maurits Biesbrouck, Expert Gregory McIntosch, Dr. Daniel Brownstein, Dr. Hans Wolff, Expert Univ. Prof. Dr. Owen Gingrich from Harvard, Dr. Armin Schlechter, late Prof. Rudolf Schmid, Dir. Dr. Patrick Gautier-Dalché, Dr. Elly Decker, Dr. Marcin Banás, Dir. Filippo Camerota, Univ. Prof. Dr. Robert J. King, Isabelle Baland, Dr. Günther Oestmann, Univ. Prof. Dr. L. Rombai, Dr. Taborska, Curator Dr. Kazimierz Kosica, Univ. Prof. Dr. Folker Reichert, Dr. Rüdiger Finsterwalder, Tina-Maria Seyfried, Dir. Dr. Jean-Pierre Luminet, Paula Gestel van het Schip, Univ. Prof. Dr. Koenraad van Cleempoel, Dr. William B. Ginsberg, Univ.Prof. Dr. David King, Mag. Andrea Missinne, Map Expert Dr. Frederik Muller, Dir. Dr. Pietro Falchetta, Dr. Leif Isaksen, Univ. Prof. Dr. Armin Wolf, Dr. Florian Mittenhuber, Prof. Dott. Vanni Gorni, Dr. M. Lehmann, Dr. Robert Karrow, Univ. Prof. Dr. C. Pedretti, Isabelle Balland, Mag. Gerhard Holzer, Univ. Prof Jean-Michel Delire, Dott. Simone Bartolini, Monica Taddei, Mme Séverine Lepape, Dr. William B. Ginsberg, Dott. Francesco Mezzalira, Autor Thomas Suárez, Mathilde Bauer, Autor Jean-Louis Biget, Francois Guibilato, Dir. Dr. Thomas Eser, Marie-Eve Cortés, Pascal Cotte, Dr. Geoff Wade, Dr. Joaquim Alves Gaspar, Prof. Dr. Augustin Hernando Rica, Univ. Prof. Dr. Alfred Stückelberger, Univ. Prof. Dr. Augustin Hernando Rica, Univ. Prof. Dr. Cédric Villani, Dr. Lorenzo Bagnoli, Dr. Monica Azzolini, Dir. Pierre-Antoine Lebel, Bernadette Moglia, Dr. Estelle Leutrat, Univ. Prof. Dr. Richard W. Clement, Prof. Dr. Nick Campion, Mestna Knjiznica Piran, Dr. Nadja Tercon, Dr. Johan Ickx,, Dr. Giorgio Marini, ConDoc Claudia Gaggetta Dalaimo, Dir. Dr. Piero Falchetta, Prof. Enrico Gamba, Don Jason Hubbard, Pierre-Antoine Lebel, Univ.Prof. Dr. Thomas Hockey, Univ. Prof. Dr. Robert J. King, Univ. Prof. Dr Toscano Gennaro, Dr. Leif Isaksen, David Missinne, Univ. Prof. Dr. Darril Rutkin, Dr. Fabio Seller, Dr. Frank Berger, CEO Richard Stenning, Curator Margaret Borg, Dr. Alida C. Metcalf, Dr. Franz-Graf Stuhlhofer, Univ. Prof. Pr. Dr. Helmuth Grössing, Dr. Aurélien Ruellet, Sibylle Reiff, Univ Prof. Dr. Norbert Kössinger, Robin

\footnotetext{
${ }^{170}$ The size of birth certificates in the US differs from state to state. The one in Maryland has the size of $17 \mathrm{~cm} \mathrm{x} 24 \mathrm{~cm}$ or $63 \%$ of the size of the globe gore map. A curious feature...the proportion of the paper size birth certificate of Maryland of 0.71 follows the ancient Renaissance paper proportion...
} 
Kinross, Univ. Prof. Dr. Darin Hayton, Univ. Prof. Dr. Nick Kanas, Heike Birkenmaier, Dr. Daniel Mosser, Nicolas Champion, Dott Silvio Leydi, Univ. Prof. Dott. Andrea Cantile, Dir. Christophe Vellet, Dr. Jérome Sirdey, Bernard Desprats, Cédric Trouche, Dr. Orest Rarum. Dr. Cédric Michon. Anne-Bénédicte Levollant. Mme Elonore Buffler, David K. Frasier, AFHEPP President Denis Peaucelle, Peter Galezowsky, Sarah McElroy Mitchell, Meredith Mann, Jacqueline Vons, Univ. Prof. DDr. Heinz Schilling, Univ. Prof. L. Missotten, Josette Telford,Dir. Joel Silver, Kimberly Nusco, Paul Riffault, Marine Lefèvre, Roberta LeMieux, Dipl. Librarian Christian Hogrefe, Editorial Assistant Yaqin Yan, Chief Editor Prof. Dr. Raffaele Pisano.

\section{References}

Aiton, E. J. (1987). Peurbach's Theoricae Novae Planetarum: A Translation with Commentary. Osiris, 2/3, 5-44. http://dx.doi.org/10.1086/368660

Almagià, R. (1951). On the Cartographic Work of Francesco Rosselli. Imago Mundi, 8, 27-34. http://dx.doi.org/10.1080/03085695108591976

Avezac (1867). Martin Hylacomylus Waltzemüller ses ouvrages et ses collaborateurs, Challamel Ainé. Paris: LibrairieÉditeur.

Azzini, E. (2012). UT VIGINTI SEX TABULAE AENEAE DILIGENTER EXCULPERENTUR. Domizio Calderini e l'Edizione della Cosmographia Tolemaica (Roma, 1478). Camenae No 10, Février 2012.

Azzolini, M. (2013). The Duke and the Stars: Astrology and politics in Renaissance Milan, President and Fellows of Harvard College, Harvard: Harvard University Press.

Babics, J. (1987). The Celestial and Terrestrial Globes of the Vatican Library Dating from 1477 and Their Maker Donnus Nicolaus Germanus. Der Globusfreund, 35-37, 155-168.

Bacquet, J., \& de Ferriére, C. (1744) Les oeuvres de Me Jean Bacquet, Avocat du Roy en Chambre du Tresor. In C.-J. de Ferriére (Ed.), Tome Premier, Chap. XXI. Lyon: MDCCXLIV.

Biget, J. L. (1994). Sainte-Cécile d'Albi: Peintures. Toulouse: Éditions Odyssée.

Borgioli, C., \& Rombai, L. (2013). Amerigo Vespucci e i Mercanti Viaggiatori Fiorentini del Cinquecento a cura di Margherita Azzari e Leonardo Rombai. Firenze: University Press.

Brosseder, C. (2014). A Companion to Astrology in Renaissance. Leiden: Brill.

Brunet, J. C. (1860-78). Manuel du librairie et de l'amateur de livres, 6 vols et supplement. Paris: Destombes, Marcel, ed.

Bruscoli, F. G. (2013). Giovanni da Verrazzano in Amerigo Vespucci e i Mercanti Viaggiatori Fiorentini del Cinquecento, a cura di Margherita Azzari e Leonardo Rombai. Firenze: Firenze University Press.

Buck, A., Klaniczay, T., \& Németh S. K. (1989). Geschichtsbewustsein und Geschichtsbeschreibung in der Renaissance. Budapest: Akadémiai Kiadó és Nyomeda Vállalat.

Cabayé, O. (2001). Un humaniste méconnu: Loys Boulengier d'Albi, mathématicien, cosmographe et géographe. Revue Historique 2001/3 (n. 691), 671-693. http://dx.doi.org/10.3917/rhis.013.0671

Campbell, T. (1978). The Romweg-Map as a Physical Object. Imago Mundi, Nr. 30, 79-91. http://dx.doi.org/10.1080/03085697808592470

Campbell, T. (1987). The Earliest Printed Maps, 1472-1500. London: The British Library.

Cantile, A. (2003). Leonardo the Genius and the Cartographer. Firenze: Istituto Geografico Militare.

Carpetto, G. (2001). Fractured Renaissance Tales of Old: The Population Plague. Lincoln: Writers Club Press.

Ceradini, G. (1894). A proposito dei due Globi Mercatoriani 1541-1551. Pubblicazione interrotta per la morte dell'Autore.

Charpin-Feugerolles, \& Hyppolyte André Suzanne de (1893). Les Florentins à Lyon, Librairie ancienne. Lyon: Librarie Ancienne Louis Brun.

Cohen, J. (1988). The Naming of America: A Fragment We've Shored against Ourselves. The American Voice, 56-72.

Crozes, M. H. (1873). Monographie de la cathédrale de Sainte-Cécile d'Albi. Paris: Victor Didron.

Duclos, C. P. (1806). Oeuvres complètes de Duclos, Tome Troisième. Paris: Chez Delaunay.

Durand, D. B. (1952). The Vienna-Klosterneuburg Map Corpus of the Fifteenth Century. Leiden: Brill.

Elter, A. (1896). P.P.O de Henrico Glareano geographo et antiquissima forma, Americae commentatio. Bonnae: Georg.

Evans, J. (1998). The History and Practice of ancient astronomy. New York, Oxford: Univ. Press.

Finsterwalder, R. (1998). Peter Apian als Autor der sogenannten, Ingolstädter Globusstreifen? Der Globusfreund, 45-46, 177-186. 
Fiorino, M. (1899). Sfere terrestri e celesti di autore italiano oppure fatte o conservate in Italia. Roma: Società Geografica Italiana.

Fumagalli, G. (1893). Pietro AMAT di S. Filippo, Raccolta di Documenti e Studi publicati dalla R. Commissione Colombiana per Quarto Centenario dalla Scoperta dell'America Parte VI-Volume Unico. Roma: Della Geografia di America.

Gaggetta, C. (2013). Louis II d'Amboise et les fresques de la cathédrale Sainte-Cécile d'Albi, in Le Duché de Milan et les commanditaires francais, (1499-1521) (pp. 287-321). Paper of a Colloquium, 30-21./3.2012, Geneva, Ed. Viella Roma.

Galezwoski, P. (2013). The Quest for Ptolomy in Alexandria and Warshaw, in History and Cartography. BIMCC Newsletter, 46, 20-23.

Galleries, P.-B. (1950). The World renowned Hauslab-Liechtenstein World Global Map of 1507 by M. Waldseemüller. New York: Parke-Bernet Galleries.

Gallois, L. (1890). Les Géographes Allemands de la Renaissance. Thése pour le Doctorat. Paris: E. Leroux.

Gallois, L. (1892). Lyon et la découverte de l'Amérique. Bulletin de la Société de Géographie de Lyon, 11, 93-114.

Gallois, L. (1904). Le nom d'Amérique et les grandes Mappemondes de Waldseemüller de 1507 et 1516 . Annales de Géographie, 67/13, 29-36. http://dx.doi.org/10.3406/geo.1904.6639

Gautier Dalché, P. (2007). The Reception of Ptolomy Cartography (End of the Fourteenth to Beginning of the Sixteenth Century). In: The History of Renaissance Cartography. Chicago: University of Chicago Press.

Guckelsberger, K. (2013). Das moderne Kartenbild von Europa auf der Carta Itineraria Waldsemüllers von 1511/1520. Cartographica Helvetica, 48, 34-48.

Guilelmus, \& de Wissekerke, G. (1494). Super caelestium motuum indagatione sine calculo. Cremona: Carolus de Darlerius.

Guilhiermoz, P. (1913). De l'Équivalence des anciennes mesures. A propos d'une publication récente. Bibliothéque de l'école de Chartres, 74, 267-328. http://dx.doi.org/10.3406/bec.1913.448498

Hamon, P. (1994). L'argent du Roi, Les Finances sous François Premier. Paris: Ed. IGPDE.

Harisse, H. (1892). The Discovery of North America, London: H. Stevens.

Harris, E. (1985). The Waldseemüller World Map. A Typographical Appraisal. Imago Mundi, 37, 30-53. http://dx.doi.org/10.1080/03085698508592586

Heale, M. (2014). The Prelate in England and Europe, 1300-1560. York: York Medieval Press.

Heawood, E. (1905). Glareanus: His Geography and Maps. The Geographical Journal, 25/6, 647-654. http://dx.doi.org/10.2307/1776451

Hessler, J. (2007). The Naming of America: Martin Waldseemüller's 1507 World Map and the Cosmographiae Introductio. Washington: Library of Congress.

Hessler, J. W. (2006). Warping Waldseemüller: A Phenomenological and Computational Study of the 1507 World Map. Cartographica, 41/2, 101-113. http://dx.doi.org/10.3138/N328-6721-3282-122N

Holst, N. (1999). Mundus, Mirabilia, Mentalität, Weltbild und Quelle des Kartographen J. Schöner. Frankfurt/Oder: Scripvaz.

Hoskin, M. (1999). The Cambridge Concise History of Astronomy. Cambridge: Cambridge Univ. Press.

Humboldt, A. (1837). Examen critique de l'histoire de la géographie nouveau, Tome Quatrième, Section Deuxième. Paris: Librairie de Gide.

King, R. J. (2014). Tadeusz Estreicher and the Jagiellonian Globe. The Globe, Journal of the Australian and New Zealand Map Society Inc., 75, 16-28.

Knutsen, T. R. (1999). The Rise and Fall of World Orders. Manchester: Manchester University Press.

Koeman, C. (1980). The Astrolabium Catholicum. Revista da Universidade de Coimbra, XXVIII, 67-76.

Kuttner, S. (2013). The Worldfocus on Munich. Munich: Bibliotheksforum Bayern, 7, 112-115.

Laffitte, M.-P. (2003). Les reliures executés pour Henri II, conservées á la Bibliotèque nationale de France. Henri II et les Arts. Paris: Ecole du Louvre.

Laubenbeger, F. (1959). Ringmann oder Waldseemüller. Eine kritische Analyse über den Urheber des Namens Amerika. Erdkunde, XIII/3, 163-179.

Lefaivre, L. (2005). Leon Battista Alberti's Hypnerotomachia Poliphili: Recognizing the Architectural Body in the Early Italian Renaissance. Caimbridge (Mass.): First MIT Press.

Lehmann, M. (2008-2010). Die „Der Welt Kugel” - Der Nachweis der Autorschaft Martin Waldseemüllers. Wolfenbüttler Renaissancemitteilungen. Vol. 32, 153-162.

Lynam, E. (1960). Ornament, Writing and Symbols on Maps, 1250-1800. Edinburgh: The Geographical Magazine.

Mano, J. M. (1980). Water Symbolization in Fifteenth and Sixteenth Century Maps, Research Paper (pp. 21-29). New York: Department of Geography. S.U.N.Y. College at the New Paltz. 
Marcel, M. G. (1889). Louis Boulengier d'Albi, Astronome, Géomètre et Géographe. Bulletin de géographie historique et descriptive, 1, 164-166.

Martin, P. (2012). Une Renaissance Lorraine, 1508-1608. Metz: Éditions Serpenoise.

Maruska, M. (2008). Johannes Schöner, Homo est nescio qualis Leben und Werk eines fränkischen Wissenschafters an der Wende vom 15. zum 16. Jahrhundert. Ph.D. Thesis.

McIntosh, G. C. (2012). The Johann Ruysch and Martin Waldseemüller World Maps. The Interplay and Merging of Early Sixteenth Century New World Cartographies. Long Beach, CA: Plus Ultra Publishing Co.

Meurer, P. (2007). State Context of Renaissance Mapping, Cartography in the German Lands, 1450-1650. Chicago: Univ. Chicago Press.

Missinne, S. (2013). A Newly Discovered Early Sixteenth-Century Globe Engraved on an Ostrich Egg: The Earliest Surviving Globe Showing the New World. The Portulan. Journal of the Washington Map Society, 87, 8-24.

Nordenskiöld, A. E. (1973). Facsimile Atlas to the Early History of Cartography with Reproductions of the Most Important Maps Printed in the XV and XVI Centuries. Reprint, New York: Dover.

Olcottt G. N. (1904). Thesaurus Linguae Latinae Epigraphicae. A Dictionary of the Latin inscriptions. Rome: Loescher \& Co.

Orsier, J. (1911). Henri Cornélius Agrippa: Sa vie et son oeuvre d'après sa correspondance (1486-1535). Paris: Bibliothéque Charcornac.

Pastoureau, M. (1984). Les Atlas Francais XVIe-XVIIe siécles. Paris: Bibliothèque Nationale.

Peckham, J. (1504/1510). Jo. Archiepiscopi Cantuariensis Perspectiua communis. Venetiis: Sessa.

Pendergrass, J. N. (2007). Letters and Fragments von Jean de Pins. Geneva: Librairie Droz.

Percival Horton-Smith, H., \& Harold, R. A. (2013). Johannes de Mirfeld of St. Bartholemew's Smithfield: His Life and Works. Cambridge: Cambridge University Press.

Peyrat, N. (1870). Histoire des Albigeois, II. Vol. Paris: Librairie Internationale.

Pins, J. (2007). Letters and Letter Fragments. Genéve: Libr. Droz.

Poulle, E. (1961). L'Equatoire de Guillaume Gilliszoon de Wissekerke. Physis, Rivista di Storia della Scienza, 3/3, $223-251$.

Ragnow, M. (2013). The Waldseemüller Globe Gores: Some Challenges and Observations. Paper Presented for the Philips Society Spring Meeting, Loc, 17 May 2013.

Ruge, S. (1892). Die Entwicklung der Kartographie von Amerika bis 1570. Gotha: Perthes.

Sabin, J. (1885). Dictionary of Books Relating to America from Its Discovery to Its Present Time. Vol. XV, Office LoC, NY.

Schmeidler, F. (2007). Schöner Johannes. Neue Deutsche Biographie, 23, 405-407.

Schwartz, S. I. (2007). Putting America on the Map. New York: Prometheus Books.

Setton, K. M. (1994). The Papacy and the Levant, 1204-1571, Vol. III, 161. Philadelphia: The American Philosophical Society.

Severino, N., \& Aked, C. K. (1997). International Bibliography of Gnomonica. West Drayton: Roccasecca.

Shauger, F. (2008). Angouleme, the European Name for the City of New York. NY Map Society.

Shirley, R. W. (1998). The Mapping of the World. Early Printed World Maps 1472-1700. London: New Holland Publishers Ltd.

Sider, S. (2005). Handbook to Life in Renaissance Europe. Oxford: Oxford University Press.

Siraici, N. G. (1987). Avicenna in Renaissance Italy, the Canon and Medical Teaching in Italian Universities after 1500. Princeton: Princeton Legacy University.

Snyder, J. P. (2003). Map Projections in the Renaissance, History of Cartography, the History of Renaissance Cartography: Interpretive Essays (Vol. 3, Part 1, pp. 365-381). Chicago: University of Chicago Press.

Stevenson, E. L. (1908). Marine World Chart of Nicolo De Canerio Januensis 1502 (Circa) a Critical Study. New York: De Vinne Press.

Stevenson, E. L. (1921). Terrestrial and Celestial Globes. New Haven: Yale University Press.

Stuart, D. M. (2000). Early Globes at the Stewart Museum, Sphaera Mundi. By EH Dahl and J.F. Gauvin. Duke (D.W.): Mc Gill Queen University Press.

Tewes, G., \& Rohmann, M. (2002). Der Medici-Papst Leo X und Frankreich: Politik, Kultur und. In: Spätmittelalter und Reformation, neue Reihe, 19. Tübingen: Mohr Siebeck.

Thrower, N. J. W. (1979). Terrae Incognitae, New Light on the 1524 Voyage of Verrazzano. Terrae Incognitae, 11/1, 59-65. 
http://dx.doi.org/10.1179/tin.1979.11.1.59

Tilley, A. (1994). The Literature of the French Renaissance (Vol. I). Cambridge: Cambridge University Press.

Tilly, A. (1918). The Dawn of Renaissance. Cambridge: Cambridge University Press.

Uhden, R. (1939). The Oldest Portuguese Original Chart of the Indian Ocean, A.D. 1509. Imago Mundi, 3, 7-11. http://dx.doi.org/10.1080/03085693908591858

Unger, M. J. (2008). Magnifico, the Brilliant life and violent times of Lorenzo de'Medici. New York: Simon \& Schuster.

Van Duzer, C. (2002). The Cartography, Geography, and Hydrography of the Southern Ring Continent, 1515-1763. Orbis Terrarum, 8, 115-158.

Van Duzer, C. (2012a). Details, Date, and Significance of the Fifth Set of Waldseemüller's Globe Gores Recently Discovered in the Munich University Library. Translated by David Palacios. Terra Brasilis, 1, 1-16.

Van Duzer, C. (2012b). Waldseemüller's World Maps of 1507 and 1516: Sources and Development of his Cartographical Thought. The Portulan. Journal of the WMS, 85, 21-34.

Van Wissekerke, W. G. (1965). Liber Desideratus, 1494, Reprint in Dutch Classics on History of Science. Nieuwkoop: B. De Graaf.

Vaughan, R. (2004). Charles the Bold: The Last Valois Duke of Burgundy, Vol 4. Woodbridge: Boydell Press.

Vignaud, H. (1912). Americ Vespuce, L'attribution de son nom au nouveau-monde. Extrait du journal de la societé des Américanistes de Paris. Nouvelle Série, Tome IX, 239-299.

White, L. T. (1978). Medieval Religion and Technology. Collected Essays, UCLA.

Wickersheimer, E. (1979). Danielle Jacquart, Supplément au Dictionnaire biographique des médecins en France au Moyen age. Genève: Droz.

Wieser, F. (1907). Die Cosmographiae Introductio des Martin Waldseemüller. Strasbourg: J. Heitz.

Winsor, J. (1884). Narrative and Critical History of America. Boston and New York: Houghton, Mifflin and Company.

Woodward, D. (2001). Il ritratto della Terra. Nel segno di Masaccio: L'invenzione della prospettiva, ed. Filippo Camerota, Florence, Giunti, 259-261.

Webpages: accessed prior to January $21^{\text {st }} 2015$.

http://www.christies.com/lotfinder/LargeImage.aspx?image=http://www.christies.com/lotfinderimages/d45160/d4516 015x.jpg

https://archive.org/stream/bulletinnewyork12librgoog\#page/n26/mode/2up/search/lyons

http://www.ksbm.oeaw.ac.at/ scripts/php/PPO.php?vol=4

http://epub.ub.uni-muenchen.de/13138/1/Cim. 107-2.pdf

http://umedia.lib.umn.edu/node/88357? mode=basic

http://www.christies.com/lotfinder/lot details.aspx?intObjectID=4516015

http://www.piccard-online.de/bilder/einleitungen/002.pdf

http://www.newadvent.org/cathen/11068a.htm

http://www.mapthematics.com/ProjectionsList.php?Projection=203\#Baconglobular

http://upload.wikimedia.org/wikipedia/commons/3/3c/1482 Cosmographia Germanus.JPG

www.paris-sorbonne.fr

http://dl.ub.unifreiburg.de/diglit/apian1521/0004/image?sid=91a48a80b8fb925da849a51a2b793565\#current page

http://www.graphpad.com/quickcales/ttest2/

http://www.leonardodigitale.com/

http://www.ciuhct.com/online/docs/thesis joaquim gaspar 2010-v2.pdf

http://www.persee.fr/web/revues/home/prescript/article/bec 037362371913 num 741 448498? Prescripts Search $\underline{\text { tabs1 } 1=\text { standard \& }}$

http://www.royalcollection.org.uk/collection/912496/a-political-allegory

http://gallica.bnf.fr/ark:/12148/btv1b550004419/f166.image.r=Cosmographia.langDE

http://bildsuche.digitalesammlungen.de/index.html?c=viewer \& l=de \& bandnummer=bsb00032959 \& pimage=00191 $\underline{\&} \mathbf{v}=100 \&$ nav $=$

http://bildsuche.digitalesammlungen.de/index.html?c=viewer $\&$ l=de \& bandnummer=bsb00032959 \& pimage=00192 
$\underline{\&} \mathbf{v}=100 \&$ nav $=$

\begin{tabular}{ccccccc} 
https://books.google.at/books?id=2WuMyEzani8C & & $\&$ & pg=PA134 & \& & lpg=PA134 & $\&$ \\
\hline dq=concordat+Francis+I+and+Pope+Leo $+X$ & $\&$ & source=bl & \& & ots=KyUfPNIMH3 & \& \\
\hline
\end{tabular}

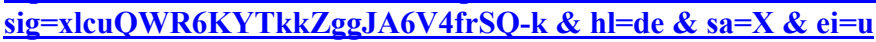

http://upload.wikimedia.org/wikipedia/commons/e/e4/Ptolemaios 1467 CBN Polona Scandinavia.jpeg

http://www.cairn.info/zen.php?ID ARTICLE=RHIS 013 0671\#re50no50

http://racineshistoire.free.fr/LGN/PDF/Robertet.pdf

www.catholique-tarn.cef.fr

www.catholic-hierarchy.org/diocese/dalbi.htlm

https://www.academia.edu/5411676/ Louis II d Amboise et les fresques de Sainte-C\%C3\%A9cile \%C3\%A0 Al bi https://www.academia.edu/5411676/ Louis II d Amboise et les fresques de Sainte-C\%C3\%A9cile \%C3\%

A0 Albi

http://upload.wikimedia.org/wikipedia/commons/3/33/Nave of the Ste Cécile Cathedral - 2014-02-22.jpg?uselang= $\underline{\text { fr }}$

http://upload.wikimedia.org/wikipedia/commons/3/3c/1482 Cosmographia Germanus.JPG?uselang=de

www.ksbm.oeaw.ac.at/ scripts/php/loadRepWmark.php?rep=briquet \& refnr=13452 \& lang=fr

www.cite-episcopale-albi.fr

http://upload.wikimedia.org/wikipedia/commons/9/9b/Plan.cathedrale.Alby.png?uselang=fr

https://archive.org/stream/cosmographiaeint00wald 1\#page/n23/mode/2up

http://catalog.nypl.org/record=b14353394 S1

http://babel.hathitrust.org/cgi/pt?num $=150 \quad \& \quad u=1 \quad \& \quad$ seq $=99 \quad$ \& $\quad$ view $=1$ up $\quad \& \quad$ size $=100 \quad \&$ id=hvd.32044058255795\#view=1 up;seq=159

https://app.box.com/s/ldsrm6bqu994e1lw33s4

http://www.ksbm.oeaw.ac.at/ scripts/php/loadRepWmarkImgPDF.php?rep=BR \& refnr=8015 \& lang=fr

http://upload.wikimedia.org/wikipedia/commons/b/be/King-Hamy map.jpg

http://thebiography.us/en/longas-tomas

https://archive.org/stream/martinhylacomyl00dgoog\#page/n120/mode/2up

http://bildsuche.digitale-sammlungen.de/index.html?c=viewer \& bandnummer=bsb00007953 \& pimage=305 \& v=100

$\underline{\text { \& nav }=\& \mathrm{l}=\mathrm{en}}$

https://archive.org/stream/diecosmographiae00wald\#page/n9/mode/2up

http://daten.digitale-sammlungen.de/ db/0001/bsb00011246/images/index.html?id=00011246 fip=eayaxsqrseayayztseneayaeayaeayaeayasdasxdsyd \& no=36 \& seite $=7$

https://books.google.at/books?id=inlmGzmRmycC $\quad \& \quad$ pg=PA551 $\quad \& \quad 1 \quad$ Ipg=PA551

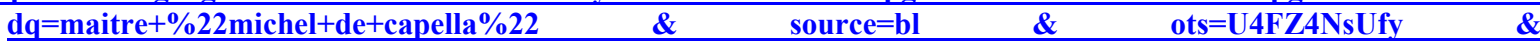
sig=Nks2vNhXGdFASqIMvz6nf60A9A4 $\quad \& \quad h \mathrm{l}=$ de $\quad \& \quad$ sa=X $\quad \& \quad$ ei=SxK6VNb-Hsv0UqiNgKgG \& ved $=0$ CBMQ6AEwAA\#v $=$ onepage $\&$ q $=\% 22$ de $\% 20$ capella $\% 22 \& \mathrm{f}=$ false

http://othes.univie.ac.at/1354/1/2008-08-07 8001863.pdf

http://www.loc.gov/resource/rbc.2008thacher16176/\#seq-113

http://reader.digitale-sammlungen.de/de/fs1/object/display/bsb10165700 $00320 . h t m l$

https://archive.org/stream/ita-bnc-in2-00002280-001\#page/n36/mode/2up

https://archive.org/stream/histoiredelimpri00vinguoft\#page/134/mode/2up/search/johannes

http://madmonarchs.guusbeltman.nl/madmonarchs/charles6/charles6 bio.htm

http://www.christusrex.org/www1/ofm/fra/FRAmis03.html

http://www.vinciclosluce.com/fichier/s paragraphe/8729/paragraphe file 1 en canal projects.p.brioist r.nanni.pdf

http://histoirededieppe.chez.com/relati00.htm

https://archive.org/stream/lesgographesall00gallgoog\#page/n81/mode/2up

http://www.newyorkmapsociety.org/FEATURES/SHAUGER2.HTM

https://razoncartografica.files.wordpress.com/2012/07/van-duzer-waldseemuller-globe-gores-munich-english.pdf. 


\section{Appendixes}

\section{LIST OF USED ABBREVIATIONS AND ACRONYMS}

CEGG: Copper engraved globe gores (= globular map)

CI: Cosmographiae Introductio

Cim: Cimilie

Div.: Division

W: Woodcut

MS: Manuscript

NYPL: New York Public Library

UB: University Library

UCLA: University of California Los Angeles

\section{Appendix 1: Transcription}

Title: MOTVS NONE SPERE ET TREPVDACIONIS OCTAVE SPERE 1514

Upper Left Corner:

EVRVS TEMPESTATES TOLIT, OCCIDENTALIS NATVRA FRIGIDVS \& HVMIDVS

AQVILO FRI GORA MA CI MA GI GVIT

VVLTVRNVS AERE PV RIFICAT COLA

Upper Right Corner:

BOREAS CVNCTA FLORIDA NEC AT SEPTEMTRIONALI NATVRA FRIGI DVS SICVS

CIRCIVS TEMPESTA INFERT CO

FAVONIVS PLVVIAS CO DVXIT CO

Lower Left Corner:

AVSTER CALORES GENERAT MERIDI ONALIS NATVRA CALIDVS \& HVMIDVS SVBSOLANVS ABSEINDIT PLVVAS CO

AFRICVS PESTEM CONSTAT COL

Lower Right Corner:

ZEFFIRVS FLORIDA PRODVCIT ORIEMTALIS NATVRA CALIDVS \& SICCVS

NOTHVS CRANDINES AFFERT COLA

C H ORVS GRADINES TOLIT CO.

INNER CIRCLE.

Depicted: A Windstar.

Days of the lunar calender circle: 1, 2, 3, 4, 5, 6, 7, 8, 9, 10, 11, 12, 13, 14, 15, 16, 17, 18, 19, 20, 21, 22, 23, 24, 25, 26, 27, 28.

TOTAL: c. 94 STARS IN DIFFERENT POSTIONS.

SYMBOLS OF SATURNUS (2 times), JUPITER (4 times), MARS (11 times), VENUS (6 times), MERCURIUS(5 times), MOON (1 time), CAPUT or LAUDA (1 time).

ALDEBARA

HIRCVS 
RIGIL

LVPVS

AVDAX

CANIMAIOR

CANIMINOR

MARE

DVBHE

CORLEONIS (The so called Regularis directs to 0 )

VRCEMAOIR

CAVDALEONI

CAPVT CORVI

SPICA

BOETES

LIBRA

CORONA SEPTE

LVPVS

COR SCORPI

SERPTENTARI

TESTVDO

AQVILA

DELPHIN

CAVDAGALI

CAVDACIGNI

EQVS

AQVARIVS

PEGASVS

CASOPIA

ANDROMADA

VENTER CETE

TRIANGVLV

CAPVTALGOL

PERSEVS

PLIADES

And the astrological symbols for the moon 5 and the planets (Mercury, Venus, Sun, Mars, Jupiter and Saturn).

Text: IN QVA LI TA TI BVZ CRISI VM IN HAC PTE MAGIS NE CESA RIS STELIS FIXIS AC IQ SARVM NA TVR IS.

SECOND CIRCLE FROM THE MIDDLE:

ARIES

THAVRVS

GEMINI

CANCER

LEO

VIRGO

LIBRA

SCORPIO

SAGITARI

CAPRICOR

AQVARIV

PICES 
Circle: Repetitive: $0(=5) 100(=15) 200(=25) 30$

THIRD CIRCLE FROM THE MIDDLE:

CIRCVLVS AVGIVM PLENETARVM

OCTAVE SPERE

AVX SOLIS ET VENERIS

AVX MARTIS

AVX IOVIS

AVX MERCVRI

AVX SATVRNI

FOURTH CIRCLE FROM THE MIDDLE:

NONE SPERE DESCRIPTIO MOTVS NONE SPERE AC TREPVDATI OIS OCTAVE SPERE PER ALIA VIA AVETARVM AC QV ORV MD AM MOD ERNORV IMAGINACIONE DISTINCTAM 1514.

Inserted: 2 small spheres.

Armillary Sphere.

One Volvelle with in the middle a wind rose. One circle with the months of the year 1,2,3,4,5,6,7,8,9,10,11,12. and one circle with 1000, 2000, 3000, 4000, 5000, 6000, 7000 .

The needle shows precisely to: $3-3 / 6$ and 1.500 (=year)! (March 15 th 1500 ?)

FIFTH CIRCLE FROM THE MIDDLE:

ARIES, THAVRVS, GEMINI, CANCER, LEO, VIRGO, LIBRA, SCORPIO, SAGITARIV, CAPRICORNV, AQVARIVS, PICES

CIFFRES: Repetitive: $0(=5) 100(=15) 200(=25) 30$

CIFFRES: 1 , 2, 3, 4, 5, 6, 7000, 8,9.10,11, 12, 13, 14000, 15, 16,17,18, 19, 20, 21000, 22, 23, 24, 25, 26, 27000, $28,29,30,31,32,33,34,35000,36,37,38,39,40,41,42000,43,44,45,46,47,48,49000$. (= years of the trepudations)

SIXTH CIRCLE FROM THE MIDDLE:

ARIES PRIMO MOBILE THORVS, GEMINI, CANCER, LEO, VIRGO, LIBRA, SCORPIO, SAGITARIVS, CAPRICORNVS, AQVARIVS, PICES.

DEDICATION TEXT AT THE BOTTOM:

AD TE CANDENTIS TERRE DIADEMATE FVLTVM

ROBERTET NOSTRE MITTITVR ARTIS OPVS

INVENIES ISTIC CVRSVS QV OS SIDERA SERVENT

ZODIACI: FIXVS QVIDVE PLANETA IVVET

NONA VALET SPHERA QVID: COELVM QVOD FERAT ORBES

HINC LVNE AC PHEBI PER SVA SIGNA GIROS

VALE.

ARTIFICIO LVDOVICI BOVLENGIER ALLEBIE 1514. 
Appendix 2: Comparative Analysis and Focused Collation of the ci* Printed in lyon

\begin{tabular}{|c|c|c|c|}
\hline $\begin{array}{l}\text { LOCATIONS AND } \\
\text { IDENFIFICATION }\end{array}$ & $\begin{array}{l}\text { AD } \\
\text { LECTOREM }\end{array}$ & $\begin{array}{c}\text { AD } \\
\text { LECTORM }\end{array}$ & $\begin{array}{l}\text { COMMENTS AND } \\
\text { WATERMARKS }\end{array}$ \\
\hline & \multicolumn{2}{|c|}{$\begin{array}{l}\text { HORIZONTA } \\
\text { L }\end{array}$} & \\
\hline & PRINT & PRINT & \\
\hline $\begin{array}{l}\text { LYON, City Lib (Rés 357275) } \\
\text { (ancien 20961) }\end{array}$ & NO & YES & $\begin{array}{l}\text { Watermark Letter B Briquet 8015, } \\
\text { Angoulême } 1505\end{array}$ \\
\hline BNF PARIS G 3482 & & YES & $\begin{array}{l}\text { Imcomplete edition } \\
\text { (only first } 6 \text { chapters) }\end{array}$ \\
\hline $\begin{array}{l}\text { BN PARIS (MAZARINE) Quarto } \\
\text { 15680-3(res) }\end{array}$ & & YES & $\begin{array}{l}\text { Partial Watermark like in the } 2 \text { copies of the CI at the } \\
\text { NYPL }\end{array}$ \\
\hline ARSENAL PARIS 4-H-33 & & $\begin{array}{l}\text { page miss- } \\
\text { ing }\end{array}$ & $\begin{array}{l}\text { Partial Watermark like in the } 2 \text { copies of the CI at the } \\
\text { NYPL }\end{array}$ \\
\hline \multirow[t]{2}{*}{ ARSENAL PARIS 4-H-32 } & \multirow[t]{2}{*}{ NO } & \multirow[t]{2}{*}{ YES } & $\begin{array}{l}\text { Partial Watermark like in the } 2 \text { copies of the CI at the } \\
\text { NYPL }\end{array}$ \\
\hline & & & $\begin{array}{l}\text { Ex Libris of the Bishop of Bourges Guillaume de Cambrais who deceased } \\
\text { in 1505.! }\end{array}$ \\
\hline BL LONDON G 6536(C.20.b.16) & & $\begin{array}{l}\text { page miss- } \\
\text { ing }\end{array}$ & No watermark found \\
\hline BL LONDON 6568.e.26 & & $\begin{array}{l}\text { page miss- } \\
\text { ing }\end{array}$ & $\begin{array}{l}\text { No information } \\
\text { available }\end{array}$ \\
\hline \multirow[t]{3}{*}{ NYPL $\quad$ KB+++ 1517 Nr. 1 Copy } & \multirow[t]{7}{*}{ NO } & \multirow[t]{3}{*}{ YES } & $\begin{array}{l}\text { A cut out onomatic ciruclar print glued on the final } \\
\text { leaf recto(F8) }\end{array}$ \\
\hline & & & $\begin{array}{l}\text { Source."Epitome"“"De Onomantia" 1578, } \\
\text { G. Pictorius }\end{array}$ \\
\hline & & & $\begin{array}{l}\text { Partial Watermark like in copy } 2 \text { at the } \\
\text { NYPL }\end{array}$ \\
\hline \multirow[t]{4}{*}{ NYPL KB+++ 1517 Nr. 2 Copy } & & \multirow[t]{4}{*}{$\begin{array}{l}\text { page miss- } \\
\text { ing }\end{array}$} & $\begin{array}{c}\text { TROSS Sample with the } 3 \text { loose copper } \\
\text { engravings }\end{array}$ \\
\hline & & & $\begin{array}{l}\text { "ROBERTETVM" /Recto A1 and”Iacobo Roberto"Verso A1 } \\
\text { scratched out }\end{array}$ \\
\hline & & & $\begin{array}{c}\text { Partial Watermark like in copy } 1 \text { of the } \\
\text { NYPL }\end{array}$ \\
\hline & & & $\begin{array}{l}\text { “Ad usum Porphyrij rufini”(handwritten on } \\
\text { title page) }\end{array}$ \\
\hline \multirow[t]{2}{*}{$\begin{array}{l}\text { LILLY LIB INDIANA E125.V6 W } \\
151517 \text { VAULT }\end{array}$} & \multirow[t]{2}{*}{ NO } & \multirow[t]{2}{*}{ YES } & $\begin{array}{c}\text { "impresio ano do } 07 " \text { This CI was rebound. Ex Libris } \\
\text { Mendel. }\end{array}$ \\
\hline & & & $\begin{array}{l}\text { Watermark Letter B Briquet } 8015 \text {, An- } \\
\text { goulême } 1505\end{array}$ \\
\hline \multirow[t]{3}{*}{$\begin{array}{c}\text { JC BROWN UL PROVIDENCE R } \\
\text { J 517.W168c }\end{array}$} & \multirow[t]{3}{*}{ YES } & \multirow[t]{3}{*}{ NO } & $\begin{array}{l}\text { No watermark found, } \\
\text { Ex Libris H. Harisse(H.H.) }\end{array}$ \\
\hline & & & $\begin{array}{l}\text { Handwritten text by H.H. on the first leaf } \\
\text { recto. }\end{array}$ \\
\hline & & & $\begin{array}{l}\text { "Mirandu Comperies" } \\
\text { (Recto p. F) }\end{array}$ \\
\hline
\end{tabular}

${ }^{*}$ Cosmographiae introductio cum quibusdam geometriae ac astronomiae principiis ad eamdem(sic) necessaries. Insuper quatuor Americi Vespucii navigationes. Colophone: Impressa per Johannem de la Place, Random Sample of the Text of the Navigations confirmed that the typesetting of the CI of Lyon was based on the CI of Waldseemüller, Examples: De castichon instead of Decastichon; Ilustrissime instead of Illustrissime; literas instead of litteras; occeani instead of oceani. Sources: Information provided by the respective libraries and bibliographical notices. 
Appendix 3: Astrolabium Phyisicum

ASTROLABIUM PHISICVM

FIRST INNER CIRCLE:

Cross Sign: DOMVS CELI PRO 45 GRADIBVS FABRICATE

SECOND INNER CIRCLE:

BELOW THE MIDDLE LINE:

MEDIAT CALIDV ORIENS: 1 DOMVS, 2 DOMVS, 3 DOMVS, MENOX MEDIAT SCICVM; 4 DOMVS, 5 DOMVS, 6 DOMVS

ABOVE THE MIDDLE LINE:

MEDIAT FRIGIDV OCIDENS: 12 DOMVS, 11 DOMVS, 10 DOMVS, MEDIAT HVMIDV MERIDIES; 9 DOMVS, 8 DOMVS, 7 DOMVS.

PARALLEL GRADE LINE:. 10, 15, 20, 25, 30, 35, 40, 45(ZENIT), 50, 55, 60, 65, 70, 75, 80, 85, 90 (with subdivisions)

LOWER CIRCULAR HOUR/DAY LINE: 7, 8, 9, 10, 11,12,1, 2, 3, 4, 5.

CIRCULAR LIST OF CRISIS:

PRIMA CRISIS:

INCHOAT CICV

TERMINATHVMIDV

CECVND INDICATI

39 PERIODVS VELINTERCADA

49 PERIODVS VELINTERCADAN

CECVNDA CRISIS:

TERMINAT CALI

INCHOAT FRIGI

TERCIVS INDICATI

59 PERIODVS VELINTERCADA

69 PERIODVS VELINTERCADA

TERCIA CRISIS:

TERMINAT CICV

INCHOAT HVMI

QVARTV INDICATI 
79 PERIODVS VELINTERCADA

89 PERIODVS VELINTERCADANS

QVARTA CRISIS:

TERMINAT FRI

INCHOATCALI

19 PERIODVS VELINTERCADAN

29 PERIOD VELINTERCADAN

CIRCLE WITH DEGREES OF LATITUDE:

$10,20,30,40,50,60,70,80,90,100,110,120,130,140,150,160,170,180,190,200,210,220,230,240,250,260,270,280,2$ $90,300,310,320,330,340,350,360$.

HOUR OF THE DAY CIRCLE: (Time scale: Limbus)

$12,11,10,9,8,7,6.5,4,3,2,1$.

$12,11,10,9,8,7,6,5,4,3,2,1$.

WIND DIRECTIONS CIRCLE:

AVSTER,

EVRO NOTVS,

EVRVS,

SVBSO LANVS,

VVLTVRNVS,

BOREAS AQVILO,

SEPTENTRIO,

CIRCIVS,

VELZEPHIRVS CHORVS,

FAVONIVS,

APHRICVS LIBO,

AFRICVS AUSTRO.

@ Dr. S. MISSINNE 


\section{Appendix 4: List of Sources}

A) Figures and data for the Compilation 2 used with permission of the New York Public library rare book division, Astor, Lenox and Tilden foundations:

Figure 1, Figure 1*, Figure 1**, Figure 1A, Figure 1B, Figure 3A, Figure 3B, Figure 1C, Compilation 2 Figure 4, Figure 5, Figure 5B, Figure 9

B) Figure used with the permission of the City Library of Offenburg: Figure 2A. Globular Woodcut Map (1 out of 4).

3) Figure used with the permission of the UB of the LMU Munich, Cim. 107 \#2: Figure 2B. Globular Woodcut Map UB Munich.

C) Figure 6 used with the permission of the City Library of Lyon: Watermark of the CI of Lyon

D) Figure 10 used with the permission of the J.C.Brown University Library: Date of the CI of Lyon.

E) Compilation file: Source: Dr. Georg Zotti, LBI ArchPro. 